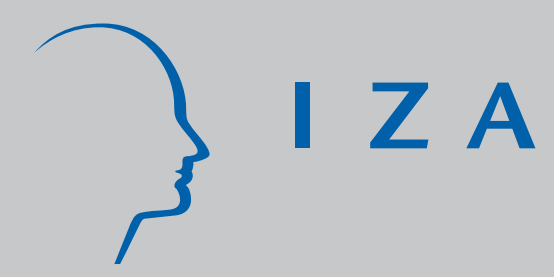

IZA DP No. 1387

Sex Differences in Managerial Style:

From Individual Leadership to

Organisational Labour Relationships

Eduardo Melero

November 2004 


\title{
Sex Differences in Managerial Style: From Individual Leadership to Organisational Labour Relationships
}

\author{
Eduardo Melero \\ Universitat Pompeu Fabra \\ and IZA Bonn
}

\section{Discussion Paper No. 1387 \\ November 2004}

\author{
IZA \\ P.O. Box 7240 \\ 53072 Bonn \\ Germany \\ Phone: +49-228-3894-0 \\ Fax: +49-228-3894-180 \\ Email: iza@iza.org
}

\begin{abstract}
Any opinions expressed here are those of the author(s) and not those of the institute. Research disseminated by IZA may include views on policy, but the institute itself takes no institutional policy positions.
\end{abstract}

The Institute for the Study of Labor (IZA) in Bonn is a local and virtual international research center and a place of communication between science, politics and business. IZA is an independent nonprofit company supported by Deutsche Post World Net. The center is associated with the University of Bonn and offers a stimulating research environment through its research networks, research support, and visitors and doctoral programs. IZA engages in (i) original and internationally competitive research in all fields of labor economics, (ii) development of policy concepts, and (iii) dissemination of research results and concepts to the interested public.

IZA Discussion Papers often represent preliminary work and are circulated to encourage discussion. Citation of such a paper should account for its provisional character. A revised version may be available directly from the author. 


\section{ABSTRACT \\ Sex Differences in Managerial Style: From Individual Leadership to Organisational Labour Relationships*}

This paper deals with sex differences in managerial behaviour, by testing the extent to which such differences match those expected from gender stereotypes. Unlike previous research on the topic, always based on opinions about individual managers, this investigation uses firm-level evidence from the British 1998 Workplace Employment Relationship Survey (WERS 98). This means that some problems usually present in individual-level studies, including answer stereotyping and selection of female managers into specific responsibilities, are avoided in the research presented here. The results show that workplaces where the presence of women at management is higher are driven in a more democratic fashion, with more interpersonal and interactive relationships between managers and subordinates, and with more employee-mentoring responsibilities undertaken by managers. No sex differences were found for more structural policies, such as the degree of delegation on supervisors or the extension of payment by results.

JEL Classification: M54, J53

Keywords: managerial style, gender behavioural differences, human resources policies

Eduardo Melero

Department of Business and Economics

Universitat Pompeu Fabra

C/ Ramon Trias Fargas 25-27

Barcelona 08005

Spain

Email: eduardo.melero@upf.edu

\footnotetext{
* I want to thank Maia Güell, Miguel Ángel Malo, Neus Palomeras and Elena Reutskaja for their useful comments.
} 


\section{Introduction}

This paper investigates whether the currently increasing presence of women at firm's managerial ranks is affecting organisational labour relationships policies. This is done through the analysis of the firm-level evidence that the 1998 Workplace Employment Relationship Survey (WERS 98) provides about labour issues in British firms.

Men and women tend to differ not only in their actual social behaviour, but also in the way they are expected to behave in society. However, the former sex behavioural differences do not always match the latter gender behavioural differences. This happens in most social contexts and, as it is explained along this paper, organisations' managerial settings are not an exception: beyond social beliefs derived from gender behavioural stereotypes, individual-level studies seem to have found there some differences in the way that women and men managers lead.

Stereotypical differences in gender roles assume that, either because of nature or nurture women's social behaviour is more people-caring oriented than that of men, with higher verbal and non-verbal communication abilities and a rather holistic approach to decisionmaking. Applying these stereotypes to managerial behaviour we have that, unless the collective of female managers came from a selected sample, women managers should lead in a more interpersonal and less task-based way than men, with more democratic (and less authoritarian) decision making. They should be as well better at managing with a "transformational" approach 2 , with higher propensity to act as mentors of their employees and establishing a more intense feedback with them.

\footnotetext{
${ }^{1}$ There is an intense and interesting debate among social psychologist to determine the extent to which sex and gender behavioural differences have a biogenetic foundation (nature) or are determined by the socialisation of individuals (nurture). To learn more about this, see Lippa (2002).

${ }^{2}$ The categorisation of leadership styles is treated in the third section of the paper. For a good introduction to it, see Bass (1974).
} 
The last decades have seen a steady increase in the proportion of women at management in all developed countries. In the United Kingdom, for example, the percentage of managers who were females increased from below $15 \%$ in the early eighties to about $30 \%$ in $2003^{3}$. Furthermore, such change does not seem to be solely brought by start up companies: the presence of women at the management of firms established before 1990, for example, increased from $18.5 \%$ to $24.4 \%$ during the period $1990-1998^{4}$. If, as it is suggested by stereotypes, women differed from men in their managerial behaviour to the limit of favouring certain employee relations policies (more democratic structures for decision making and more interactive communication, for example), this change in managerial workforce composition could be bringing a change in organisational labour relationships. Precisely, this paper examines the extent to which women managers are leading the introduction of such changes. This is made by analysing how the percentage of women at management affects organisations' human resources policies in several aspects that include task definition, decision-making, communication, delegation and retribution.

There is large survey evidence dealing with the extent to which these gender stereotypical differences materialise in real sex differences among individual managers at work ${ }^{\mathrm{G}}$. Initial research, largely influenced by feminist scholars, found little differences in the leadership styles of male and female managers, suggesting that the actual behaviour of women at administrative jobs was strongly influenced by executive role models that seemed to claim for masculinity (Henning and Jardim, 1978). Such failure to find differences between men and women in their managerial behaviour might have been importantly affected by a selection effect. First, as the recruitment of middle managers is done with this masculine role model in mind, a disproportional amount of women that do not fit into it are selected out. Second, as Lazear and Rosen (1990) explained in the context of job ladders, women that self-select into the long process of pursuing a managerial career must be productive enough as managers (within the "masculine manager" paradigm) to balance their higher opportunity cost in terms of household production. Later and more sophisticated research

\footnotetext{
${ }^{3}$ Estimations obtained from the different year releases of the National Management Salary Survey.

${ }^{4}$ Own estimations done with data from the WERS 1990-98 Panel Survey.

${ }^{5}$ See Powell and Graves (2003) for a good summary of research in both fields.
} 
(see Eagly and Johnson, 1990, and Kabacoff, 1998) seems to have found a number of differences, most of them pointing in the direction of gender stereotypes. Females' leadership approach has been described as more oriented to tasks and interpersonal relationships. Furthermore, women managers consistently appear as putting higher emphasis in mentoring and inspiring their subordinates. Less clearly, some studies also found that female managers tend to be more democratic than their male counterparts. If these differences are real, they are expected to become more intense in the future, as the higher presence of women at management and the decline of the masculine stereotype of the good manager dilute selection effects.

In this paper, I address the question of sex differences in managerial style in a rather indirect way that avoids some problems suffered by previous research. Unlike prior investigations on managerial styles that relayed on self-reported or peers-reported data, I will look directly at the policies adopted at the workplace-level and relate them to the relative presence of women at management. This has the advantage of avoiding problem of "answer stereotyping" that individual-level studies suffer. It also helps to bypass the problem of female manager's selection into specific responsibilities that individual surveys may have if they do not control for it.

Whether the potential sex differences are being translated to the organisational philosophy of an organisation and to its profitability as the presence of women in managerial ranks increases is also itself a challenging question. Top executives may serve as leadership models in an organisation, largely influencing its organisational culture and managerial interactions. Hence, as women's penetration into management levels is being more intense at low and middle levels than at the level of the board of directors $\frac{6}{6}$ such penetration may be having a rather limited effect on the global organisational behaviour setting of the firm.

\footnotetext{
6 In the USA, the percentage of women at managerial ranks is about 37\% (US Bureau of Labour Statistics 2003), while only $13 \%$ of boardroom sits are hold by female directors at large companies ("Women Board Directors of the Fortune 500", 2001 Catalyst Census). Differences are similar in the UK, where the percentage of female managers reaches the 30\% level (WERS 98 and National Management Salary Survey 2003 and 2004, CELRE) and the percentage of female directors at large companies is around 5\% (Corporate Women Directors International: www.globewomen.com/cwdi/cwdi.html)
} 
From a practical point of view, the relevance of the connection between sex composition of managerial teams and work relationships policies stems from its potential consequences for corporate performance. The increase in the proportion of women managers could be, through the promotion of certain policies, accelerating their firms' transition towards the application of "high performance work practices" (see Appelbaum et al., 2000). These practices have been often found to have a positive effect on corporate performance in manufacturing sectors through enhanced labour productivity (Capelli and Neumark, 2001; Appelbaum et al., 2000). Consistently, raw correlation coefficients between changes in British organisations in the period 1993-98 show that firms where the participation of women at management has experienced larger increases have also enjoyed larger increases in labour productivity (see more detailed discussion of it in the evidence section).

The main results obtained in this paper from the analysis of the data provided by the WERS 98 are the following ones. First, increases in the percentage of women at management ranks are associated to more intense interpersonal communication, higher involvement of managers in employee's career administration and, less clearly, to more democracy in decision-making at workplace. These results suggest that last decade changes towards more participatory management, higher involvement of employees in organisational issues and more intense manager-worker interactions might have been reinforced by an increasing presence of women at managerial ranks. Second, the percentage of females in the managerial body appears positively related to stricter definition of jobs and rather unrelated to the degree of managerial delegation on supervisors or to the use of payment by results schemes. Therefore, other recent organisational trends that aim to increase firm responsiveness to changes in global markets through higher task flexibility, increased decentralisation of decision-making and stronger direct incentives do not seem to be affected by the increasing weight of women in the administration of firms. Finally, the higher preference of women managers for certain type of policies is not reflected in especially higher ability to be more effective in implementing them. Thus, it seems that the extension of one type of policies or another is going to neither improve nor damage women's comparative advantage as managers. 
The rest of this paper is organised as follows: in next section, I explain what researchers have found up to now about the beliefs and realities of sex differences in managerial behaviour more in detail. In the third section, I develop a set of hypotheses specifying how these male/female leadership style differences should translate into differences in organisational behaviour as a function of the proportion of managerial jobs hold by women. In the fourth section, I use data from the WERS survey to test these hypotheses and discuss the results considering alternative explanations. Finally, I conclude in the last section.

\section{Gender Stereotypes and Real Sex Differences in Managerial Styles}

The fact that adult men and women are psychologically different is something much less discussed than the extent to which these differences are genetically determined or caused by differences in the socialisation of individuals. Furthermore, such differences frequently do not match differences in gender roles (i.e., differences in what society expects about the psychological qualities and behaviour of men and women). This mismatch between expected and real behavioural differences is especially important in the managerial environment, where feminine traits have often been seen incompatible with "good manager" features. Several studies replicated during the last thirty years (Schein, 1973; Brenner, Tomkiewicz and Schein, 1989; Powell, Butterfield and Parent, 2002), have consistently found that both practising managers and MBA students pursuing a managerial career perceive "good manager" characteristics as matching better the characteristics defining the masculine stereotype ${ }^{\text {? }}$.

Studies that have surveyed the description and evaluation of managers' leadership by their peers, bosses, subordinates and the managers themselves have found that there are qualitatively differences in the way men and women lead. Paradoxically they found neither significant nor consistent differences in the aggregate effectiveness of their leadership. In a meta-analysis of a large number of previous studies, Eagly and Johnson (1990) reported

\footnotetext{
${ }^{7}$ This support for the masculine role of the good manager has nonetheless diminished substantially among female managers and female potential managers in the last years, while it has remained strong among male managers.
} 
that women tend to manage in a more participative and democratic way, while male managers are more directive and autocratic. They found no evidence of differences between managers of both sexes in their reliance on interpersonal relationships or task definition for their leadership styles. Nevertheless, women seem to score higher in "transformational" style, which involves more intense interpersonal interactions to give individualised mentoring to subordinates, to serve them as managerial model and to be proactive at stimulating workers' interest in the job. Men scored higher in "Management by Default" and "laissez-faire" styles, suggesting that male managers tend to delegate more and be less proactive in supervision tasks. In an analogous study, Eagly, Karau and Makhijani (1995) found that men and women did not generally differ in their organisational effectiveness ${ }^{8}$. In a more recent work, Kabacoff (1998) matched 900 pairs of managers from different sexes, working at similar positions within the same firm, and analysed several dimensions of their managing styles and their organisational effectiveness. His results cast doubts about the more democratic leadership style of women, although the proxies used to measure it are rather indirect. This study also depicts women rating higher in both interpersonal and taskoriented styles, while male managers seem more concerned about "vision-creation"?

To sum up, any overview of the research done in the last years about sex differences in managerial style must conclude that, although there may be mixed results in specific pieces of evidence, women's style tend to be more people-oriented than that of men 10 , with no difference in the general effectiveness of men and women as managers.

\footnotetext{
${ }^{8}$ They also found, however, that men tended to rate higher in roles defined as highly masculine whereas women tended to rate higher in less masculine roles.

9 More specifically, men at management were found to be more innovative, think more in strategic terms and have a higher ability to learn from the past to learn de future.

10 The studies mentioned above have been done in the context of the United States corporate world. Nevertheless, things do not seem to differ much in Britain. Wajcman (1996) is the only study asking British men and women managers about their views of male/female differences in managerial styles. Consistently with gender stereotypes, she found that both men and women considered male managers to be more directive, aggressive and task-oriented than females, who were considered to be more participative, co-operative and people-oriented.
} 
There are some drawbacks from this studies that the approach of the present paper intends to overcome. First, the analysis of managerial behaviour differences is frequently based on managers' opinions about differences between the typical male and typical women manager or, at most, on subjective evaluations of single managers' characteristics (as provided by their bosses, subordinates, peer managers or the individuals themselves). These judgements, even in the case of self-reports, may be affected by the gender stereotypes they have in mind, especially in the case of females at male-intensive working contexts where a female worker is more characteristically women than colleague, professional or boss (Kanter, 1977). This "answer stereotyping" problem is largely avoided here by using organisationlevel instead of individual data. In the WERS 98 personnel managers are asked about the global behavioural patterns (policies) of organisation's management as a whole in their relationship with employees. By analysing the effect of increases in the percentage of female managers on the type of behavioural pattern prevailing at the management of the organisation, we can infer male/female differences in managerial behaviour through male/female differences in working relationships policies promoted.

A second advantage of the type of analysis done in this paper has to do with the type of managerial jobs usually done by women. Findings about male/female differentials in managerial style have been often neglected by the fact that presence of females is typically higher at managerial posts such as $H R$ or Controlling than at other tasks such as Engineering. As most individual-level studies fail to control for this selection into different managerial areas, they cannot distinguish the extent to which sex differences in managerial behaviour are due to differences in their leadership style or to differences in the behavioural requirements that men and women face at their job. Data from the WERS 98 does not inform about female presence at the management of the different departments that may contain a workplace. Nevertheless, analysing differences in policies among firms with different proportion of women at managerial ranks is less problematic that comparing directly individual differences between male and female managers. The reason is that higher ratios of female managers can be associated to relatively more managerial responsibilities in the hands of women even if women manager tend to be selected into specific responsibilities. 
The indirect approach to evaluate sex differences in managerial style adopted in this paper requires a specific formulation of the hypotheses to be tested. Instead of putting forward how should men and women differ in their managerial attitudes, I will hypothesise in the next section how the relative presence of women at management should affect to corresponding organisational policies.

The main limitation of the empirical strategy undertaken in this research is that workplace managers' decision power may be bounded by higher-level organisational structures. In general, it seems reasonable to assume that higher ratios of female managers are associated to more decision power in the hands of women. Nonetheless, since differences in female ratios at workplace's managerial teams are not necessarily linked to differences in female ratios at executive levels, women's different managerial style could be offset at the organisational context by their reduced presence at top executive boards. Male-dominated executive teams may design organisational structures that restrain strongly lower-rank managers' discretion to focus organisational relationships. Moreover, organisations' institutionalised models of successful leaders can be strongly influenced by the behaviour of top executives, obliging managers to adjust their behaviour to what is expected from such models. These two effects constrain what can be claimed from the obtained results. A significant effect on the degree of adoption of a given policy caused by higher presence of women at management can be said to reflect sex differences in their preferences for such policy or in their skills to apply it. On the other hand, the failure to obtain significant effects on the adoption of other policies can be due to the lack of sex differences in preferences and the aptitudes to apply such policies, but also to tight institutional constraints in the ability of workplace managers to apply their preferred policies.

Overall, the findings of this paper give a much direct a measure of the extent to which female managers are being able to bring or accelerate changes in the managerial philosophy at organisations than individual-level studies of sex differences in managerial styles. The results, however, do a better job in unveiling the specific aspects in which women managers advocate for a different focus of organisational relationships than in explaining why their relative presence at management does not make any difference in other aspects. 


\section{Hypotheses on the Organisational Consequences of Sex- Differentiated}

\section{Managerial Styles}

Are workplaces with higher presence of women at managerial ranks run in a different way? To answer this question one must first hypothesise how "different" should labour relationships be at workplaces lead by women if females' individual leadership style tended to differ from that of men in the ways explained in the previous section. Many aspects of leadership can be considered in this context. The most important of them, selected on grounds of a balance between relevance, comparability with previous studies and ability to be observed at the organisational level, are included below: the orientation of their leadership (what channels do managers use to address de actions of their subordinates), their decision-making style (whether they take decisions at the workplace in a democratic fashion or in a rather authoritative way), their involvement in subordinates' job (the extent to which they are able to mentor and serve as models and sources of motivation for employees), their reward for performance (the extent to which they associate the reward of each employee to his/her performance) and their degree of delegation (the amount of tasks that managers delegate on lower level employees). Of course, not all the aspects that define an individual managerial approach are equally transferable to organisation-level attitudes. It is probably easier to agree in a common guideline on whether managerial activities are more or less task-based than to agree in common patterns about the inspirational ability of the group of managers. Being aware of this, the following set of hypotheses is designed to predict the consequences that higher presence of women at managerial ranks should have on organisational labour relationships if female managers' differential features matched those expected from gender stereotypes and could be easily transmitted to organisational values.

\section{Orientation of Leadership: Task-Based Style}

One common dimension used to analyse managerial styles is the orientation of their leadership, i.e. the type of behaviour they may use to influence the actions of their subordinates. Researchers have commonly distinguished between task-based leadership 
style and interpersonal-relations style (see Bass, 1974) in a non-excluding way. This means that, in principle, a manager may base his/her leadership highly in both task definition and interpersonal relationships, only in one of the mentioned dimensions, or in neither of them. Specifically, task-oriented managers are characterised as relying on the definition of jobs, the assignment of projects, or the setting of goals and procedures to exert their leadership. Less task-oriented managers, on the other hand, would be less specific in the definition of jobs and objectives and might enjoy higher flexibility in the distribution of tasks.

Employees under the direction of more task-styled managers should know in more exact terms what is expected from them through the provided description of their job and goals to be achieved. In terms of gender stereotypes, a high propensity to display task-oriented managerial behaviour is normally associated to the masculine trait of more structured thinking (Powel and Graves, 2003). At the workplace level, a more task-oriented management body should involve more rigid definition of tasks with more structured jobs. Then, gender stereotypes tell us that working relationships in firms with proportionally more women at management should be less dependant on formal definition of jobs.

Hypothesis 1 (Task orientation): At organisations with higher presence of women at managerial ranks, employees' work should be less strictly tied to the formal definition of their tasks.

\section{Orientation of Leadership: Interpersonal Style}

Interpersonally oriented managers use personal contacts and interactions to influence the behaviour of their subordinates. They build their leadership on keeping the morale of their subordinates high and caring for their self-esteem by, for example, showing concern about their welfare at work or congratulating those who achieve good performance. In contrast, less interpersonally oriented managers would rely less on these activities to promote their leadership. Gender stereotypes clearly suggest that women tend more to adopt these attitudes, fitting much better into the interpersonally-oriented model of management. At firms where the interpersonal style is dominant among leaders, more frequent and more direct personal interactions between managers and subordinates should be observed. 
Consequently higher presence of women at managerial ranks should be associated to the promotion of more intense and less structured interactions between managers and employees.

Hypothesis 2 (Interpersonal orientation): At organisations with a relatively high proportion of women in the management, the personal interactions between managers and subordinates should be equal or more frequent and rely equally or less on formal interviews.

\section{Democracy in Decision-Making}

Another dimension of managerial behaviour where men and women have been found to differ is the decision-making process. Leaders that discuss potential changes with their subordinates and try to build a consensus with them to obtain a better implementation of the change are qualified as more democratic managers. Those who adopt a directive style, defining by themselves all the actions and changes to be carried through before communicating them to their subordinates are considered autocratic managers. This latter style of decision-making is more associated to the masculine stereotype, characterised by dominance and control. Conversely, the democratic style appears more related to the feminine stereotype, reflecting a higher emphasis on the involvement of others. Organisations with a more democratic behaviour among managers would result in more consultation activities and more decisions taken by the management in agreement with their employees.

Hypothesis 3 (Democracy versus Autocracy): Organisations with higher presence of women in the management should consult more to their employees before taking decisions.

\section{Transformational Style}

Most leadership studies in the last 20 years have been highly influenced by a platonic benchmark proposed by Burns (1978): the Transformational Manager. A transformational 
leader is supposed to establish high behavioural standards by acting as role model for his/her subordinates, setting with them individualised mentoring and high level of empowerment, being their constant source of inspiration and stimulation, and obtaining therefore the maximum contribution to the organisation capabilities from them. Such style is usually described by researchers in contrast to transactional style, which associates managerial relationships with subordinates to exchange relationships, and laissez-faire style, normally associated to a simple failure in fulfilling managerial activities.

Most features of the transformational style cannot be associated to either gender stereotype. Nonetheless, the more intense social behaviour of the feminine stereotype puts women in a better place to offer mentoring and encouragement to their subordinates. It is also difficult to predict which special characteristics should have a workplace with a majority of managers that fit well within the "transformational-style" category. Since this type of style was defined almost completely in terms of how the "ideal" behaviour of a manager should be composed, transformational-styled managers should add especially high value to their organisations through better and more productive labour relationships. In organisational terms, the spirit of the definition of transformational management suggests that at firms where this style is pre-eminent, there should be more frequent contacts between managers and subordinates, who should be able to report incidents, concerns or suggestions directly to their bosses. These characteristics are somehow similar to those of a firm where managers tend to use interpersonal style, not less because transformational style is itself interpersonally-based. However, it must be noticed that the special features of transformational managers is that they go further by not only building their leadership in inter-personal relationships (as interpersonally-oriented managers do), but using them to act as individual mentors of their subordinates, to provide them with challenging views of their tasks and to transmit values and excitement about the organisational objectives.

Hypothesis 4 (Transformational management): In organisations where women represent a larger proportion of the managerial ranks, the report of incidences, suggestions or concerns from labour force to management should be more direct. Employees' mentoring 
and development should be a relatively more important issue among managers at these firms.

\section{Reward for Performance}

For those managers who fail to approach the transformational behaviour, researchers have also categorised different style trends (see Bass, 1974). First, transactional leaders tend to delegate tasks, offer suitable rewards in exchange for objective accomplishment and manage "by exception", intervening only to correct their subordinates' performance. In contrast, laissez-faire managerial style covers the basic characteristics undesirable for a good manager, avoiding decision-making responsibilities, failing to provide performance feedback to their subordinates and tending to stay away from employee-development tasks 11 . As it happens with transformational style, transactional and laissez-faire styles cannot be globally associated to either the masculine or the feminine managerial stereotype. Nevertheless, there may be some gender differences in the specific assets of these styles. In particular, stereotypes that assign higher orientation to tasks to male managers also suggest that they are more likely to offer explicit rewards for performance. This is possible because they define goals and individual tasks more explicitly, so that performance can be measured more objectively. At the organisational level, the pre-eminence of males at management should result in higher incidence of payment by results schemes.

Hypothesis 5 (Contingent Reward): Payment by results should be a less common practice at firms with higher presence of women at management.

11 It must be noticed that, while laissez-faire leadership is presented as completely opposite to transformational, the concept of transactional leadership still contains some behavioural elements that fit well to the transformational approach. This is especially true in the contingent reward aspect of management, since in both approaches payment by results is an important managerial tool for the provision of incentives. 


\section{Degree of Delegation}

Finally, managers also differ in the degree to which they delegate decision making on employees. Gender stereotypes present the managerial behaviour of women as more participative than that of men to extreme of making decisions in a more democratic fashion. Such higher participation of employees in the administration of organisations may also be reflected in the amount of independence awarded to subordinates to make decisions in their working context. Therefore, gender stereotypes would suggest that women managers tend to delegate more on lower levels while male managers would tend to accumulate decisionmaking responsibilities at higher levels. In this sense, higher presence of women at management should be associated to higher degree of delegation of decisions.

Hypothesis 6 (Delegation): At firms where the proportion of female managers is higher, the degree of delegation on supervisors is higher.

\section{Evidence from UK firms}

In the previous section, I have hypothesised how the observed sex differences in managerial style, which only partially support gender managerial stereotypes, should affect organisational-level labour relationships as women gain access to managerial jobs. In order to test these hypotheses empirically, data about workplace managerial patterns is needed. The data contained in the WERS 98 survey is then the most suitable for performing this analysis from a workplace-level perspective.

The WERS 98 is a national survey of 2091 British workplaces ${ }^{12}$ selected from all workplaces with 10 or more employees through stratified random sampling. The survey consists of information about employment relations at the place of work provided by the management, a sample of employees and a representative of workers. The main source of

\footnotetext{
${ }^{12}$ Note, however, that the final number of observations used in each type of analysis of this section is lower as long as valid data for all the variables in play is needed. Specifically, the total number of observations considered for each analysis varies between 1455 and 1603 .
} 
data for the present analysis is a set of questions extracted from the Main Management Interview section, although variables from the Survey of Employees section are also used to control for workforce characteristics. A majority of the relevant issues for this paper are materialised in the survey in the form of questions that concern the degree of application of several specific policies. Therefore, most of the variables used for the analysis are coded in qualitative terms or discrete scales, as it is shown in the description of variables provided in the Appendix.

The percentage of women at managerial ranks registered at the WERS 98 survey was about $30 \%$. More than $48 \%$ percent of interviewed managers reported an increase of such proportion in their workplaces in the period 1993-1998, while only $4 \%$ stated a decrease. At the same time, a majority of managers reported increase in labour productivity (80\% against $4 \%$ that reported decrease) but also in labour costs (64\% against $16 \%$ that reported decrease). Panel A of Table 1 reflects how do these changes in performance correlate with changes in managerial workforce composition: Increases in proportion of females at management appear significantly correlated with increases in labour productivity and, less strongly, with decreases in labour costs. This would be consistent with the thesis that women managers are able to create more value through a more intensively transformational approach to management. Furthermore, correlation coefficients from Panel B of Table 1 show that those workplaces where the increase in females at management has been higher have also experienced higher increases in the importance of employee relations as strategic targets, the influence of employees on managerial decision-making, the extension of payment by results to employees and the autonomy of workers at their jobs. In other words, it seems that workplaces where the relative increase of women at management has been stronger, have also become more people caring, more democratic and rely more on contingent rewards and delegation.

The significant correlations reported above, however, do not imply any type of causality respect to the stated hypotheses. First, there can be other factors that could be causing both trends at the same time that must be controlled for, such as product and labour market conditions of the specific industry, size of the firm or age, education and occupational 
composition of the labour force. Second, several of the different policies studied here may need to be applied jointly to be truly effective. Increases in delegation, for example, are usually accompanied by increases in payment by results, in order to balance higher decision-making power awarded to employees with stronger incentives to make a good use of it. This would make difficult to identify which policies are the ones that women managers tend to promote more and which are the ones adopted complementarily. To solve the first problem, a number of relevant factors are kept constant while analysing how the proportion of women at workplace affect the extent of application of different policies. The second issue will be discussed later.

\section{Measurement of the Different Policies}

Before describing the results of the analysis, it is necessary to clarify how the different policies referred in hypotheses are measured empirically. Of course, a policy is usually something that cannot be measured in a completely objective and unequivocal fashion. For this reason, I will proxy each of them through the degree of application of one or several concrete patterns in employee-managerial relationships that can be associated to the existence of such policy.

- Hypothesis 1 states that a higher presence of managerial women makes employee's work less strictly attached to their set of specified tasks. This is measured through the variable EMPSHELP -the extent to which managers ask employees to help them in ways not specified in their job description. The higher the attachment of employee's work to their defined task, the lower the value of EMPSHELP will be. Therefore, Hypothesis 1 implies that EMPSHELP should be higher in workplace with higher proportion of women managers.

- Hypothesis 2 says that personal interactions between managers and subordinates should be equal or more frequent and equal or more informal at workplaces with higher proportion of women managers. Two variables are chosen to measure this: the extent to which management prefers to consult directly with employees instead of their 
representatives (DIRECONS) and whether managers are considered as instruments for workers to make direct suggestions (IMPRMGMT). Both variables are assumed to be directly connected to interpersonal interactions, so that both of them must be positively related to the relative presence of women at management if Hypothesis 2 holds

- Four variables are used to test the degree of democracy in decision-making at the workplace. Hypothesis 3 claims that decisions should be done in a more democratic way at workplaces where the presence of women at managerial jobs is higher. DECSATOP states whether management considers that those at top are best placed to make decision and EMPSNOCO, whether most decisions are made without consulting employees. The proportion of women at management must have a negative effect both variables if Hypothesis 3 holds. On the other hand, EMPSCHAN describes the extent to which management discusses possible workplace changes with workers before introducing them and CONSTARG codes whether managers set targets in consultation with employees or not. The presence of women at management is expected to affect positively to these two latter variables if the claim of Hypothesis 3 is true.

- Hypothesis 4 stated that employees' reporting of incidences, suggestions or concerns to management should be more direct at organisations with higher presence of women at management and that employees' mentoring and development should be a relatively more important managerial task at these workplaces. The two dependent variables chosen to test this are PARTBRIE and DISCUSS. These variables could have been partially associated to Hypothesis 2 to the extent that they are somehow related to the level of interpersonal interactions between employees and managers. Their definition, however, fits better into the particular features of the transformational leadership style for which Hypothesis 4 was designed. PARTBRIE, for example, reflects the extent to which management encourages the implication of workers in organisational issues, by dedicating more time in briefing meetings to express their points of view and suggest improvements. DISCUSS, on the other hand, is a more general index coding whether the firm uses performance appraisals to give feedback to employees, discuss their career 
moves or set their personal objectives. Hypothesis 4 predicts that both variables should be positively affected by an increase in the proportion of women at management.

- Hypothesis 5 deals with the evolution of the use of contingent rewards as the presence of women at management increases. Three dummy variables are used to measure the use of explicit payment by results: PROFREL states whether employees receive profitrelated payment; SHAROWN, whether there exist employee share ownership plans at the company and PAYPERF, whether workers at the firm are paid trough "pay per performance" schemes. All three variables should be negatively related to the proportion of women at management if, as Hypothesis 5 states, payment by results were a less common practice in firms with higher presence of women at management.

- Finally, Hypothesis 6 states that higher proportion of women at managerial positions brings more delegation on supervisors. I will use four measures of delegation on supervisors to test it, the percentage of supervisors (EMPSUPV) at the workplace and three dummies coding whether supervisors have the right to hire workers (SUPVTAKE), to decide on their pay (SUPVPAY) or to dismiss them (SUPVEDISM).

\section{Explanatory Variables}

The key variable used to test the hypotheses stated above is PROPFEMG, the proportion of managers who are females. A number of other variables that could be related at the same time to PROPFEMG and some of the policies are included in the analysis in order to control for their effect:

- The Proportion of Female Workers is included through the variable PROPWOM. A higher proportion of female managers can be the outcome of higher proportion of female employees. Since firms with relatively more women in the workforce may present specific characteristics, it is worthwhile to control for it. 
- The Sex of the Respondent Manager is coded through the dummy variable RESPFEMG. Higher proportion of female managers increases the probability that the survey's respondent manager is a women, and there are potential sex differences in the view of how employment relationships are carried out in the workplace that have to be kept under control.

- The Characteristics of the Workplace Labour Force must also be taken into account, since potential differences in age, education or the type of occupations hold by workers may also be important in determining the type of policies that can be applied. The mentioned characteristics are summarised in $A V G A G E$, the average age of workplace's employees, $A V G E D U Y R$, the average years of education of workplace's employees, and a set of variables including the proportion of workplace's employees in each of 7 different occupations. All these variables are computed average obtained from the data included in the Survey of Employees section of the WERS98.

- The Workplace Size may also be a relevant variable in explaining the extent of application of some of the policies analysed. Thus, it is controlled through the total number of employees at the workplace, NUMEMPS.

- The Autonomy of the Workplace: The ability of workplace's managers to promote a given policy and the support that they may have from the board of directors to implement it may depend on who owns the firm. For this reason, I included three dummy variables coding whether the organisation is owned by a majority of foreign capital (FOREING), whether it works for the public sector (PUBLIC), and whether it is a completely independent organisation (INDEPEND)

- The Longevity of the Workplace is measured through the number of years that the workplace has been operating $L O N G E V$. The rationale for including it as a control variable relies in that policies are usually easier to implement over "green field" than on well-established workplaces. 
- The Sector where the organisation is operating is controlled through 12 dummy variables associated to the 1-digit SIC 1992 code. Technological differences across industries may be huge, and they may have an influence in both the possibilities of women to obtain managerial positions and the type of policies that can be adopted.

- The presence of any type of Union at the workplace may have an influence on women' chances to arrive to managerial jobs in that workplace and, at the same time, affect their ability to introduce specific policies.

\section{Estimation Results}

Tables 2 to 7 show the results form the Ordered Logit 13 analysis of the effect that the ratio of females at workplace's management may have on the extent of application of different employment relationship policies. The results, in relation to what previous research has found about each managerial style associated to each policy, are described below.

Individual-survey evidence discredits the role assignment setting proposed in Hypothesis 1. Eagly and Johnson (1990) did not find any sex difference in task style and the differences found by Kabacoff (1998) portrayed women as more intense task-styled managers than men. Somehow consistently with this evidence, the results depicted in Table 2 are closer to deny than to support Hypothesis 1. The effect of PROPFEMG on EMPSHELP is negative in all the presented models, although it losses its statistical significance when we control for the ratio of females at workplace (PROPWOM) and the sex of the manager in charge of human resources relationships at the firm (RESPFEMG). The high correlation between PROPFEMG and PROPWOM, (correlation coefficient is 0.65) or between PROPFEMG and PROPWOM (correlation coefficient is 0.41 ) suggest that the observed negative effect of Model I could be in fact reflecting the effect of a larger proportion of women at workplace or the larger incidence of a women in charge of labour relationships. On the other hand, estimates from the rest of the models (for this and the rest of dependent variables) might suffer a problem of multicollinearity, a failure to disentangle the effects of

\footnotetext{
${ }^{13}$ See Maddala (1983) to learn about the structure and distributional assumptions behind this method
} 
the three variables. All in all, the negative effect of female ratio at management in Model I on EMPSHELP (significant at the 10\% level) and the consistently negative effect registered even after controlling for the female ratio at workplace and sex of the respondent manager, seem to go against Hypothesis 1. Model V includes an interaction effect between the proportion of managers and the percentage of women at workplace. Although the value of such interaction is not significant, its negative sign suggests that the presence of women at management has a more negative effect on the flexibility of task definition if the proportion of women at workplace is also high. Kabacoff (1998) argued that the finding that women tend to score higher in task-oriented leadership style could be associated to higher vulnerability of women at management that makes them more needed of explicit rules and higher security of having the job done. In this sense, the negative interaction from Model V is at least counterintuitive, since a higher proportion of women in the workforce should imply a less strongly masculine model of the good manager $\frac{14}{\text { and higher ability of }}$ women managers to be flexible in task definition.

Individual-level studies on sex differences in the interpersonal orientation of leadership weakly support the gender stereotype behind Hypothesis 2. The meta-analytical findings of Eagly and Johnson (1990) stated that women tend score higher than men in interpersonal style in laboratory experiments and assessment studies with non-leaders, but were not able to find similar differences for actual managers. Kabacoff (1998), on the other hand, found a significantly stronger interpersonal orientation in the managerial style of women managers. As it can be observed from Table 3, both DIRECONS and IMPRMGMT are positively affected by PROPFEMG. In first case, the effect is only significant at standard levels when we do not control for the proportion of women at workplace. In the second case, the coefficient is only significant once the proportion of women at workplace is accounted for. Both results back Hypothesis 2 as long as they reflect that interpersonal interactions of managers and subordinates are more intense at organisations where the presence of women at management is higher. Neither RESPFEMG nor PROPWOM have a consistent effect

\footnotetext{
${ }^{14}$ As stated by Powell, Butterfield and Parent (2002) the association between the stereotypical characteristics of the good manager and masculine characteristics is currently lower among female than among males.
} 
across the two mentioned proxies of the degree of interpersonal orientation of working relationships.

Consistently with the predictions of gender stereotypes, most studies have found that women tend to be more democratic and less autocratic leaders than men (Eagly and Johnson, 1990). An exception is the case of Kabacoff (1998), where the small sex differences found in democratic decision-making suggested that women could be even more authoritarian than men in the same managerial position $\frac{15}{1}$ The results displayed in Table 4 are also mixed. As the Panels 4.2 and 4.3 depict, the variables directly related to whether management consults or not with employees (EMPSCHAN and, especially, EMPSNOCO) are clearly affected by the proportion females at management in the direction that Hypothesis 3 predicts. Furthermore, the significant interaction effects of PROWOM and PROPFEMG on both variables suggest some type of synergies that makes female managers behave more democratically when their subordinates are mostly women. On the other hand, the estimated effects of PROPFEMG on DECSATOP and CONSTARG were not significant.

A distinctive feature of variable DECSATOP is that it does not require the interviewed manager to describe the general managerial behaviour at the workplace as other questions do, but it asks him/her about his/her opinion on who has the relevant information and power to make decisions, so that one would perhaps expect personal characteristics of the respondent to especially affect the answer. In this respect, it is remarkable (and consistent with Hypothesis 3) the result from Panel 4.1 that female respondents significantly consider "those at top" worse placed to make decisions than male respondents do.

The only variable for which the effect of female managers ratio contradicts Hypothesis 3 is CONSTARG, which reflects a much more specific aspect of managerial decision-making

\footnotetext{
15 The author of this latter study argued that such mismatch with the literature could be due to a selection effect in the previous studies by which women generally tend to occupy functions and levels that require a more democratic style. To the extent that his study controls for this issues by matching male and female managers from the same organisation at the same level, his results should be more valid.
} 
-target setting- than the rest of variables. Therefore one could argue that this particular variable reflects worse than the rest the general managerial attitude towards democratic decision-making as it is more affected by the idiosyncrasy of target-setting decisions. Overall, the lack of significant effects of PROPFEMG on these two "indirect" measures of decision-making implies that findings of Table 4 cannot be claimed to provide more than a weak support to Hypothesis 3.

There is a large degree of agreement among the existing individual-survey evidence in that female leaders are more transformational, as predicted by gender stereotypes. Studies from different countries have found that women managers tend to score higher in managerial attributes such as charisma, inspirational motivation and individualised consideration of subordinates than their male counterparts (Carless, 1998; Eagly and Johannesen-Schmidt, $2001)^{16}$. Consistently with such survey evidence, Hypothesis 4 is strongly supported by the results of this paper. As the two panels of Table 5 show, PROPFEMG is positively associated to both measures of the extension of a transformational style among managers, PARTBRIE and DISCUSS, with consistent and significant effects in all specifications. Managerial teams with higher ratio of females encourage more the implication of workers and are more intensive in collecting performance appraisals to improve worker's performance and discuss career paths. The proportion of women at workplace, on the other hand, does not seem to have a significant role in determining managerial behaviour, neither directly nor through its interaction with the ratio of females at management. The last columns of both panels of Table 5 show non-significant interaction effects with opposite signs, so that it is not clear whether tendency of female managers towards a more transformational leadership style steps up or decreases with the proportion of women among their subordinates.

\footnotetext{
${ }^{16}$ Interestingly, survey evidence that assigns such higher scores to women in styles associated to higher effectiveness (transformational), also assigns to men higher scores in styles assigned to lower effectiveness (laissez faire) (Lowe, Kroeck and Sivasubramaniam, 1996). At the same time, studies on effectiveness (Eagly et al., 1995; Kabacoff, 1998) reveal that the overall perceived effectiveness of female managers is not larger than that of men. This suggests the existence of other behavioural features affecting managerial effectiveness out of the axis transformational-laissez faire styles where men could be enjoying some advantage.
} 
Researchers that studied sex differences in managerial style have also addressed the extent of use of contingent rewards. As in the case of task-style orientation of management, their findings seem to go in the opposite way to what gender stereotypes predict. Eagly and Johannesen-Schmidt (2001) found that women tend to score higher in the contingent reward dimension of managerial style, being therefore more likely to establish concrete compensations for well-done jobs. The results exhibited in Table 6 show that PROPFEMG has no significant effect on none of the three measures of payment by results (PROFREL, SHAROWN, and PAYPERF), and that the sign of the effect varies across dependent variables and specifications. Hence, female managers cannot be said to rely more or less than males in contingent rewards (at least for the explicit part of them), so that neither the gender managerial stereotypes behind Hypothesis 5 nor individual survey evidence on managerial sex differences in explicit rewards for performance are supported in Table 6. It is interesting to note that firm characteristics, such as INDEPEND (the independence of the organisation), FOREING (its ownership by foreign capital) and PUBLIC (its public service character) are more important in explaining the adoption of payment by results plans than the sex composition of the managerial body. This would suggest that explicit incentive policies such as those analysed in Table 6 are rather structural and strongly determined by top-executives' decisions. In this sense, the lack of significant effect of PROPFEMG on neither dependent variable may be due to the low influence that managers out of the board of directors have over the adoption of incentives policies at the organisational level.

The results of Eagly and Johannesen-Schmidt (2001) suggested that male managers, who scored higher in "management by exception" and laissez faire managerial style, tended to delegate more than their female equivalents. The results depicted in Table 7 seem more consistent with this evidence than with the gender roles that determined Hypothesis 6. The sign of the estimated coefficients of PROPFEMG on the different measures of delegation on supervisors (EMPSUPV, SUPVTAKE, and SUPVPAY) is negative in almost all specification for all measures of delegation considered, but it is never statistically significant. Hypothesis 6 is then clearly not supported by the results of this paper. 
Summing up, the results depicted in Tables 2 to 7 support the hypotheses that, at workplaces with higher ratios of women at management, manager-employee interactions are more intense and interpersonal, with higher a involvement of the former in the career development of the latter. There is also some support in this evidence for the hypotheses that at workplaces with proportionally more women managers, the decision-making process is carried out in a more democratic fashion. In contrast, the hypothesis that higher presence of women at management implies stricter definition of tasks, with less explicit payment by results and more delegation on supervisors are definitively not sustained by the data.

\section{Robustness Check and Quantitative Assessment}

Most of the ordered logit estimates presented in Tables 2 to 7 correspond to effects over dependent variables that are coded in more than two categories. This implies that the results may be driven by an especially large effect on the probability of achieving a single category. In order to check the robustness of the results presented above, I compressed each dependent variable coded in three or more categories into two categories and applied binomial logit analysis. The sign and significance of the relevant estimates pointed in

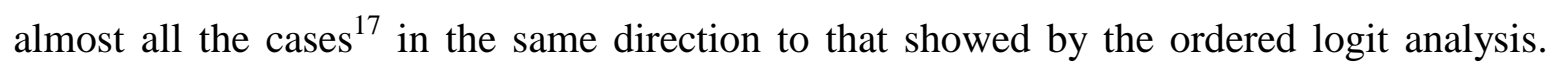
Furthermore, the differences in estimates across different models showed in each panel of Tables 2 to 7 were mimicked in the compressed case.

An advantage of the binomial logit analysis is that it allows us to give a quantitative assessment of the estimated significant effects through the computation of estimated marginal effects at the mean. In the case of interpersonal relationships, for example, the results imply that an increase in $10 \%$ in the proportion of female managers is expected to increase between $0.7 \%$ and $1 \%$ (depending on the model) the probability that the

\footnotetext{
${ }^{17}$ Since most of the dependent variables were coded in terms of a discrete scale of "agreement" from 1 to 5 , where option 3 represented "neither agree nor disagree", I applied a more conservative method of compressing the categories, which assigned categories 1 to 3 to a "tend to disagree" category and categories 4 and 5 to a "tend to disagree" category. I also explored an alternative method, which included category 3 into the "tend to agree" category. The results were substantially the same for the relevant variables, except in the case of EMPSHELP, for which no significant effect of PROPFEMG was found in the compressed approach.
} 
respondent manager "tends to agree" with the statement that "managers rather consult directly with employees than with representatives", keeping all the covariates at the mean. A quantitatively similar effect is found for the probability that "managers are considered a channel through which employees can make suggestion". With respect to the extent of democracy on the workplace, $10 \%$ increases in the presence of women at management are associated to increases between $0.3 \%$ and $0.8 \%$ in the probability of "tending to agree" with the statement that "managers discuss with workers any change before introducing it" and to decreases between $0.7 \%$ and $1 \%$ in the probability of "tending to agree" with the statement that "most decisions at workplace are made without discussing them with employees". Finally, the largest effects are found for variables related to "Transformational Management": $10 \%$ increases in the proportion of women at managerial ranks are associated to estimated increases between $0.9 \%$ and $1.4 \%$ in the probability that "more than $25 \%$ of the time in briefing meetings is given to employees to offer views and pose questions" and to estimated increases between $0.8 \%$ and $1.1 \%$ in the probability that "the firm uses performance appraisals to give feedback to employees, discuss their career moves and set their personal objectives". Although these figures give an idea of the relative importance of the sex composition of the managerial team on the type of labour relationship policies adopted, it must be taken into account that, by the construction of the logit estimator, the estimated marginal effects may differ strongly from those reported here as firm characteristics differ from the average.

\section{Potential Correlation Between Policies}

An important issue that we must tackle before discussing these results is the potential effect of the correlation between the different dependent variables considered here. Complementarity between several organisational policies could make them more profitable when applied jointly instead of separately. Therefore, we might see that, in practice, policies are usually implemented "in packages" rather than in isolation (Milgrom and Roberts, 1995) and have difficulties to assert that the observed effect of female ratio at management over a given policy variable is not in fact reflecting such correlation with other relevant policy variables. Table 8 shows the matrix of sample correlations for the different 
proxies for policies used in the previous analysis. As it can be observed, correlations between variables that proxy different policies are rather small (all of them below 0.2 and most of them below 0.1 ), but statistically significant in most cases, so that potential complementarities cannot be ruled out. To explore the extent to which the policies approached by our variables are adopted "in bundles", I performed principal components and maximum likelihood factor analysis to identify potential higher level "policy trends" associated to especially high or low degree of implementation of several of the 16 dependent variables considered in Table 2. The results from the factorisation, presented in Table 9, discourage a generalisation of the analysed proxies on meta-variables capturing different policy trends. The rotated factors obtained from both methods seemed to be associated to a strong presence of either a single variable or, at most, one of the policy groups defined by the hypotheses stated in the previous section $\frac{18}{18}$ This suggests that correlation between policies should not be an important problem for interpreting regression results of Tables 2 to 7 . On the other hand, the information contained in these variables did not appear easily summarised in a few factors or components. Principal components analysis, for example, revealed that at least 10 components would be needed to capture a $75 \%$ of the total variance, encouraging the researcher to maintain the analysis of each of the policy variables separately on grounds of ease of interpretation.

\section{Female Managers, Policies and Performance}

The evidence presented above shows that the way workplaces are managed varies with sex composition of the managerial team, and that such differences are consistent with some of the sex differences found in individual managerial behaviour. Conversely, other differences observed at the individual manager level do not seem to translate to the workplace scope. One argument for this discrepancy is found in the "glass ceilings" (Powell, 1999) that keep women from achieving executive positions. The intensity of interpersonal contacts, the degree of worker mentoring or even the amount of democracy in decision-making are "softer" aspects of managerial tasks where each manager has to fully decide how to cope

\footnotetext{
${ }^{18}$ Specifically, Hypothesis 3 (democratic decision-making) Hypothesis 5 (payment by results) and Hypothesis 6 (delegation) are individually well captured by the different factors retained.
} 
with. In contrast, the degree of decentralisation of responsibilities and the extension to employees of payment by results schemes are "harder" aspects of the organisational policy, more related to the rules imposed by the organisational structure designed at executive ranks. Hence, to the extent that the presence of women at executive boards is much lower that at the rest of the administrative bodies even in firms with a high percentage of female managers, policies related to delegation and incentives will be much less affected by the sex composition of managerial teams. At the same time, this evidence also implies that women's individual tendency towards a more task-based, interpersonal, democratic and employee-mentoring orientation in their leadership style is not limited by the potential masculine role modelling of a male-dominated executive body. Overall, this finding suggests that if, as usually claimed in the literature, sex differences in leadership orientation are constrained in practice by a disproportionately larger presence of men at top levels $\frac{19}{19}$, such constraints would come from male-designed organisational structures rather than from female managers' attempts to fit to a male-manager role model.

As stated before in the paper, individual leadership studies that assign higher amount of transformational attributes to women suggest that female managers should be better at motivating and obtaining commitment from employees. To the extent that the empirical analysis shows evidence consistent with Hypothesis 2 and 4 that generalise this attribute to the workplace level, organisations with higher proportion of female managers should obtain a greater performance from encouraging more interpersonal and interactive managersubordinate relationships. To deal with this issue, I will investigated how the different policies analysed above affect firms' performance and, especially, how the effect of this policies depends on the presence of women at the management. Thought the WERS 98 does not provide any objective measure of performance, managers are asked to evaluate the degree of commitment of workers to the values of the organisation (FULLYCOM) and three other aspects of performance at their organisation in comparison to the rest of the industry: labour productivity $(\angle A B P R O D)$, product quality $(P R O D Q U A L)$ and financial performance (FINPERF). Although these subjective answers are likely to be biased upwards (most managers state that their workplace perform better than the average of the industry in all

\footnotetext{
${ }^{19}$ See Powell and Graves (2003) for the specific case of the UK, see Li and Wearing (2002)
} 
aspects), variation in answers will capture well variation in actual performance as long as the excess of optimism displayed by managers is correlated neither with actual performance levels nor with our explanatory variables. Taking this into account, I performed Ordered Logit Regression analysis to capture the effect over these performance measures of the six types of policies analysed above and their interaction with female ratios. The regression accounts for the same firm and workforce characteristics used previously in the paper plus additional controls for other organisational policies that could affect performance and, at the same time, be correlated with other policies $\underline{20}$.

The results of such analysis are displayed in Table 10. For each measure of performance, the first specification depicted includes the effect on it of each policy, while the second model shows how such effect depends on the presence of women at management and the proportion of women at workforce. Less strict definition of tasks and more participative decision-making seem to have a significant positive effect over the commitment of workers to firm's values. On the other hand, more interpersonal manager-employee relationships do not seem to have such effect, although the extension of the specific practices of the transformational manager (captured by PARTBRIE and DISCUSS) do also affect positively to workers' commitment. In general, however, these described significant effects are not found for the rest of performance measures; only EMPSCHAN PARTBRIE registered a statistically significant effect over the perceived labour productivity and quality of the main product, and only the latter has a significant effect over the workplace's financial performance. Interestingly, the opposite happens with measures of payment by results, which either do not have a significant effect or have a significantly negative effect on the

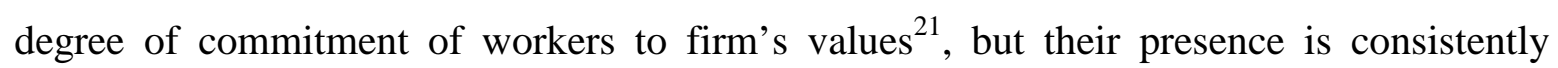

20 Specificlly, these include the extent the firm offers long term employment relationship to workers (LTEMPLOY), the degree to which vacancies are filled with promotions from within (WITHINPR), whether the firm has a formal policy for equal opportunities employment (FOREQOPS) and whether it has a special policy to hire women returning to work after childbearing $(E M P M O T H)$.

${ }^{21}$ Specifically, there is a significant negative relationship between the existence Pay per Performance schemes and the commitment of the workers to the values of the organisation. This is consistent with the traditional theory of human resources that predicts some substitution between intrinsic and extrinsic motivation to work (see Baron and Kreps, 1998). 
associated to higher financial performance in all cases. As for delegation, no consistent linkage appeared between its different proxies and the measures of performance.

To investigate whether manager women perform better at applying the policies that they seem to "prefer", the second specification of each dependent variable of Table 10 shows the extent to which their effect on performance depends on female ratios of women at management (keeping constant the moderating effect of the proportion of women at management). In general, the results do not sustain the idea that women at management are better at implementing the policies that they tend to apply. Female managers, for example, tend to be stricter in task definition but, as the interactions of $H E L P \times F E M G$ show, a more flexible task definition has a more positive effect on the commitment of workers and organisational financial performance when the presence of women at management is higher. Similarly, while female managers seemed to promote more interpersonal employment relationships, the benefits from them seem to increase significantly as the female ratios at management decrease. No significant or consistent interactions were found between the effectiveness of rest of policies and the proportion of women managers applying them.

On the whole, results from Table 10 tell us that the inclination of women managers for certain type of policies is more related to personal preferences or lower personal costs to carry them out than to any comparative advantage they may have in their application. In this sense, these results are not as optimistic as Rosener (1990) in suggesting the superiority of women at managing in a more interpersonal and interactive way. They rather support the line of Wajcman (1996) in claiming that male managers can be in principle as effective as females in applying such "softer" managerial style.

In general, the message that can be extracted from the evidence analysed in this section is that several of the individual sex differences in managerial style found at the individual level are also found in organisational policies while others are not. Hence, as sex composition of workplace's managerial team changes, polices related to worker-employee direct interactions change substantially, while policies related to organisational structure 
seem to remain unaffected. As it happens with individual sex leadership differences (see Powel and Graves, 2003), the disparities in preferences for organisational policies by sex composition of management do not seem to translate to differences in performance at applying such policies.

There are, of course, limitations of this analysis. One of them is the fact that all the considered dependent variables are coded in discrete scales that reflect the assessment of managers about organisation-wide issues. Theses subjective assessments are, by definition, subject to biases in the perception and interpretation of reality by the respondent and might lead to artificial correlations if the interviewed managers were heterogeneous in their biases. This problem, however, is balanced against deeper organisational introspection that allows us to observe policy variables that cannot be measured objectively. A second problem is potential unobserved heterogeneity and its relationship with the analysed variables. The effects identified along this paper control for an important set of organisational issues and industrial dummies. Nevertheless, there might be some other unobserved factors affecting both female ratios at management and policy variables that would be therefore biasing the estimated effects. This problem can be partially solved if one can observe how changes over time in female ratios at management correlate with changes in policies 2 . Unfortunately, neither the 1990-98 WERS Panel Survey 23 nor, up to my knowledge, other panel studies are able to approach the different policies of our analysis as the WERS 98 does.

\footnotetext{
${ }^{22}$ Such differences-in-differences analysis is only effective to control for fixed unobserved effects, while it does not control for changes over time in unobserved factors that could be correlated with changes over time in both dependent and explanatory variables.

${ }^{23}$ The 1990-98 WERS Panel Survey is a survey run by the same time than the WERS 98, where a sample of about 900 surviving organisations that have been surveyed in the WIRS 1990 study (a former equivalent of the WERS 98) were interviewed again about a number of issues. These issues, however, didn't include a detailed description of the organisational employment practices as the WERS 98 does.
} 


\section{Concluding remarks}

Feminist literature has evolved in the last thirty years from discrediting the idea that women lacked the needed capabilities to perform managerial tasks (see, for example, Henning and Jardim, 1978) to denounce the role of male-oriented organisational cultures in preventing female managers from exploiting their specific leadership strengths (see Hearn and Parkin, 1987). The results displayed in the previous section encourage a different view of this issue, since they show that the managerial approach to relationships with subordinates is more in line with those "feminine qualities" at workplaces where women represent a higher proportion of the managerial team. The "masculine constraint" is therefore shown to have, at most, a limited effect.

On the opposite extreme of the debate, a number of authors like Loden (1985) and, especially, Rosener (1990) have predicted that the highly transformational and interactive leadership style of women will suit better than the masculine "command an control" style to the context of today's less hierarchical and more flexible organisations where teamwork is more important. The results of this paper seem to fit well to the idea that women are, at least in labour relationships aspects, developing a different leadership style and implementing different policies as long as they are suitable to organisations' structural needs. This, however, does not seem to be reflected in females' better organisational performance at applying their preferred policies.

Policy measures related to provision of explicit incentives and delegation on supervisors do not seem to be affected by the presence of women at workplace's management. These results could be reflecting either the non-existence of sex differences in these areas of decision or the inability of workplace managers to decide in these aspects. Decisions about decentralisation of decision-making and the establishment of reward systems are usually considered rather structural components of organisational design (see Brickley, Smith and Zimmerman, 2001), at least in comparison to the rest of the policies analysed in this paper. Therefore, the fact that these are the only two sets of variables for which no effect was 
found suggest the existence of such a structural rigidity preventing workplace managers from going too far in these aspects.

Although women are becoming more and more present at managerial teams, their access to boards of directors is still rather limited. Given that top executives play the double role of designing organisational structures and serving as models for lower level managers, the sex composition of organisational executive bodies may be an important factor to complement the findings of this paper. In this sense, having data about the different rates of female executives at boards of directors will improve importantly future investigations in this topic. 


\section{$\underline{\text { References }}$}

Appelbaum, E., T. Bailey, P. Berg and A. Kalleberg (2000): Manufacturing Advantage: Why High Performance Work Systems Pay Off. Ithaca, New York: ILR Press.

Baron, J.N. and D.M. Kreps (1998): Strategic Human Resources Frameworks for General Managers. New York: John Wiley \& Sons.

Bass, B.M. (1974): “An Introduction to Theories and Models of Leadership" in R.M. Stogdill (Ed.): Handbook of Leadership (pp. 37-55). New York: Free Press.

Brenner, O.C., J. Tomkiewicz and V.E.Schein (1989): “The Relationship between Sex Role

Stereotypes and Requisite Management Characteristics Revisited," Academy of Management Journal, 32, pp.662-669.

Brickley, J., Smith, C. and Zimmerman (2001): Managerial Economics and Organisational Architecture. $2^{\text {nd }}$ Ed. Boston: McGraw-Hill.

Burns, J.M. (1978): Leadership. New York: Harper \& Row.

Capelli, P. and D. Neumark (2001): "Do "High Performance" Work Practices Improve Establishment Level Outcomes?," Industrial and Labor Relations Review, 54, pp.737-775.

Carless, S.A. (1998): "Differences in Transformational Leadership: An Examination of Superior, Leader, and Subordinate Perspectives," Sex Roles, 39, pp.887-902.

Eagly, A.H. and M.C. Johannesen-Schmidt (2001): "The leadership Styles of Women and Men," Journal of Social Issues, 57, pp.781-797.

Eagly, A.H. and B.T. Johnson (1990): "Gender and Leadership Style: A Meta-Analysis," Psychological Bulletin, 108, pp. 233-256. 
Eagly, A.H., S.J. Karau and M.G. Makhijani (1995): "Gender and the Effectiveness of Leaders: A Meta-Analysis," Psychological Bulletin, 117, pp. 125-145.

Hearn, J. and W. Parkin (1987): Sex at Work: the power and Paradox of Organization Sexuality. Brighton: Weathsheaf Books.

Henning, M. and A.Jardim (1978): The Managerial Woman. London: Marion Boyars.

Kabacoff, R.I. (1998): Gender Differences in Organizational Leadership, Portland: Management Research Group (available at www.mrg.com).

Kanter, R. M. (1977): Men and women of the Corporation. New York: Basic.

Lazear, E.P. and S. Rosen (1990): "Male-Female Wage Differentials in Job Ladders," Journal of Labor Economics, vol 8(1), S106- S123.

Li, C. A. and R.T. Wearing (2004): "Between Glass Ceilings: Female Non-Executive Directors in UK Quoted Companies," International Journal of Disclosure and Governance, vol 1, 1-17.

Lippa, R.A. (2002): Gender, Nature and Nurture. Mahwah: Erlbaum.

Loden, M. (1985): Feminine Leadership, or How to succeed in Business without Being One of the Boys. New York: Times Books.

Lowe, K.B., K.G. Kroeck and N. Sivasubramaniam (1996): "Effectiveness Correlates of Transformational and Transactional Leadership: A Meta-Analytic Review of the MLQ literature," Leadership Quarterly, 7, 385-425.

Maddala, G. (1983): Limited Dependent and Qualitative Variables in Econometrics. New York: Cambridge University Press. 
Milgrom, J. and P. Roberts (1991): "6Complementarities and Fit: Strategy, Structure, and Organizational Change in Manufacturing," Journal of Accounting and Economics, vol 19, 179-208.

Schein, V.E. (1973): “The Relationship between Sex Role Stereotypes and Requisite Management Characteristics," Journal of Applied Psychology, vol 57, 95-100.

Powell, G.N. (1999): "Reflections on the Glass Ceiling: Recent Trends and Future Prospects" in G.N. Powell (Ed.): Handbook of Gender and Work (pp. 325-345). Thousand Oaks: Sage.

Powell, G.N., D.A. Butterfield and J.D. Parent (2002): "Gender and Managerial Stereotypes: Have the Times Changed?," Journal of Management, vol 28, 177-193.

Powell, G.N and L.M. Graves (2003): Women and Men in Management ( ${ }^{\text {rd }}$ Edition). Thousand Oaks: Sage.

Rosener, J. B. (1990): “Ways Women Lead” Harvard Business Review, 68/6, pp.119-125.

Wajcman, J. (1996): "Desperately Seeking Differences: Is Management Style Gendered," British Journal of Industrial Relations, vol 34(3), pp.333-349. 


\section{$\underline{\text { Tables }}$}

Table 1: Correlation between the evolution of the proportion of women in managerial posts and changes in organisational policies and outcomes in the period 1993-1998. Correlation coefficients, with their corresponding p-values in parentheses.

Panel A: Labour Costs and Productivity Outcomes

$$
\text { CHLABPRO }
$$

CHLABCST

$\begin{array}{ccc}\text { CHPROFMG } & 0.105 & -0.043 \\ (0.000) & (0.062)\end{array}$

\section{Number of}

Observations

1881

1887

Panel B: Organisational Policies

CHEMPREL

CHDECMAK

CHPBR

CHEMPINF

CHPROFMG

0.118

0.174

(0.000)

0.071

(0.002)

0.105

(0.000)

1926

1925

1909

1926

Number of

Observations 
Table 2: Effect of the proportion of women at management on the degree to which management ask employees to help them in ways unspecified in their task definition. Ordered Logit estimates with standard errors in parentheses.

\begin{tabular}{|c|c|c|c|c|c|}
\hline $\begin{array}{c}\text { Dep. Var.: } \\
\text { EMPSHELP }\end{array}$ & $\underline{\underline{\text { Model II }}}$ & $\underline{\underline{\text { Model II }}}$ & $\underline{\underline{\text { Model III }}}$ & $\underline{\underline{\text { Model IV }}}$ & $\underline{\text { Model V }}$ \\
\hline PROPFEMG & $\begin{array}{c}-0.342^{*} \\
(0.187)\end{array}$ & $\begin{array}{l}-0.142 \\
(0.207)\end{array}$ & $\begin{array}{l}-0.280 \\
(0.200)\end{array}$ & $\begin{array}{l}-0.078 \\
(0.220)\end{array}$ & $\begin{array}{l}0.438 \\
(0.519)\end{array}$ \\
\hline PROPWOM & & $\begin{array}{c}-0.638^{* *} \\
(0.287)\end{array}$ & & $\begin{array}{l}-0.641^{* *} \\
(0.220)\end{array}$ & $\begin{array}{l}-0.477 \\
(0.324)\end{array}$ \\
\hline$F E M G \times W O M$ & & & & & $\begin{array}{l}-0.754 \\
(0.687)\end{array}$ \\
\hline RESPFEMG & & & $\begin{array}{l}-0.091 \\
(0.105)\end{array}$ & $\begin{array}{l}-0.094 \\
(0.105)\end{array}$ & $\begin{array}{l}-0.091 \\
(0.105)\end{array}$ \\
\hline$N U M E M P S \times 10^{-3}$ & $\begin{array}{l}0.189^{* *} \\
(0.081)\end{array}$ & $\begin{array}{l}0.185^{* *} \\
(0.081)\end{array}$ & $\begin{array}{l}0.189^{* *} \\
(0.081)\end{array}$ & $\begin{array}{l}0.185^{* *} \\
(0.081)\end{array}$ & $\begin{array}{l}0.177^{* *} \\
(0.081)\end{array}$ \\
\hline$A V G A G E$ & $\begin{array}{l}-0.002 \\
(0.010)\end{array}$ & $\begin{array}{l}-0.004 \\
(0.010)\end{array}$ & $\begin{array}{l}-0.002 \\
(0.010)\end{array}$ & $\begin{array}{l}-0.003 \\
(0.010)\end{array}$ & $\begin{array}{l}-0.003 \\
(0.010)\end{array}$ \\
\hline$A V G E D U$ & $\begin{array}{l}0.036 \\
(0.035)\end{array}$ & $\begin{array}{l}0.025 \\
(0.035)\end{array}$ & $\begin{array}{l}0.038 \\
(0.035)\end{array}$ & $\begin{array}{l}0.027 \\
(0.035)\end{array}$ & $\begin{array}{l}0.023 \\
(0.035)\end{array}$ \\
\hline UNION & $\begin{array}{l}-0.125 \\
(0.125)\end{array}$ & $\begin{array}{l}-0.107 \\
(0.126)\end{array}$ & $\begin{array}{l}-0.129 \\
(0.125)\end{array}$ & $\begin{array}{l}-0.111 \\
(0.126)\end{array}$ & $\begin{array}{l}-0.110 \\
(0.126)\end{array}$ \\
\hline INDEPEND & $\begin{array}{c}-0.239^{*} \\
(0.129)\end{array}$ & $\begin{array}{l}-0.245^{*} \\
(0.129)\end{array}$ & $\begin{array}{c}-0.240^{*} \\
(0.129)\end{array}$ & $\begin{array}{c}-0.244^{*} \\
(0.129)\end{array}$ & $\begin{array}{l}-0.251^{*} \\
(0.129)\end{array}$ \\
\hline FOREING & $\begin{array}{l}0.240 \\
(0.170)\end{array}$ & $\begin{array}{l}0.226 \\
(0.170)\end{array}$ & $\begin{array}{l}0.238 \\
(0.170)\end{array}$ & $\begin{array}{l}0.225 \\
(0.170)\end{array}$ & $\begin{array}{l}0.232 \\
(0.170)\end{array}$ \\
\hline PUBLIC & $\begin{array}{l}-0.123 \\
(0.167)\end{array}$ & $\begin{array}{l}-0.128 \\
(0.168)\end{array}$ & $\begin{array}{l}-0.121 \\
(0.168)\end{array}$ & $\begin{array}{l}-0.126 \\
(0.168)\end{array}$ & $\begin{array}{l}-0.128 \\
(0.168)\end{array}$ \\
\hline LONGEV & $\begin{array}{l}0.002 \\
(0.001)\end{array}$ & $\begin{array}{l}0.002 \\
(0.001)\end{array}$ & $\begin{array}{l}0.002 \\
(0.001)\end{array}$ & $\begin{array}{l}0.002 \\
(0.001)\end{array}$ & $\begin{array}{l}0.002 \\
(0.001)\end{array}$ \\
\hline $\begin{array}{l}\text { 1-digit Industry } \\
\text { Dummies }\end{array}$ & Yes & Yes & Yes & Yes & Yes \\
\hline $\begin{array}{c}\text { Percentages of } \\
\text { Workforce in each } \\
\text { Occupation }\end{array}$ & Yes & Yes & Yes & Yes & Yes \\
\hline $\begin{array}{l}\text { Number of } \\
\text { observations }\end{array}$ & 1601 & 1601 & 1601 & 1601 & 1601 \\
\hline$L-R$ test $\chi^{2}$ & $80.20^{* *}$ & $85.14^{* *}$ & $80.96^{* *}$ & $85.95^{* *}$ & $87.15^{* *}$ \\
\hline
\end{tabular}

Significant at the $10 \%$ level. ${ }^{* *}$ Significant at the $5 \%$ level 
Table 3: Effect of the proportion of women at management on the degree of interpersonal interactions at the organisation. Ordered Logit estimates with standard errors in parentheses.

Panel 3.1: Extent to which Managers Consult Workplace Issues Directly to Employees

\begin{tabular}{|c|c|c|c|c|c|}
\hline $\begin{array}{l}\text { Dep. Var.: } \\
\text { DIRECONS }\end{array}$ & $\underline{\underline{\text { Model I }}}$ & $\underline{\text { Model II }}$ & $\underline{\underline{\text { Model III }}}$ & $\underline{\underline{\text { Model IV }}}$ & Model V \\
\hline PROPFEMG & $\begin{array}{l}0.361^{*} \\
(0.186)\end{array}$ & $\begin{array}{l}0.242 \\
(0.205)\end{array}$ & $\begin{array}{l}0.440^{* *} \\
(0.199)\end{array}$ & $\begin{array}{l}0.336 \\
(0.218)\end{array}$ & $\begin{array}{c}-0.284 \\
(0.514)\end{array}$ \\
\hline PROPWOM & & $\begin{array}{l}0.339 \\
(0.289)\end{array}$ & & $\begin{array}{l}0.340 \\
(0.289)\end{array}$ & $\begin{array}{l}0.139 \\
(0.326)\end{array}$ \\
\hline$F E M G \times W O M$ & & & & & $\begin{array}{l}0.909 \\
(0.683)\end{array}$ \\
\hline RESPFEMG & & & $\begin{array}{l}-0.115 \\
(0.105)\end{array}$ & $\begin{array}{l}-0.116 \\
(0.105)\end{array}$ & $\begin{array}{l}-0.121 \\
(0.105)\end{array}$ \\
\hline$N U M E M P S \times 10^{-3}$ & $\begin{array}{c}-0.296^{* *} \\
(0.075)\end{array}$ & $\begin{array}{c}-0.296^{* *} \\
(0.075)\end{array}$ & $\begin{array}{c}-0.296^{* *} \\
(0.075)\end{array}$ & $\begin{array}{c}-0.296^{* *} \\
(0.075)\end{array}$ & $\begin{array}{c}-0.286^{* *} \\
(0.076)\end{array}$ \\
\hline$A V G A G E$ & $\begin{array}{c}-0.025^{* *} \\
(0.010)\end{array}$ & $\begin{array}{c}-0.024^{* *} \\
(0.010)\end{array}$ & $\begin{array}{c}-0.025^{* *} \\
(0.010)\end{array}$ & $\begin{array}{c}-0.024^{* *} \\
(0.010)\end{array}$ & $\begin{array}{c}-0.024^{* *} \\
(0.010)\end{array}$ \\
\hline$A V G E D U$ & $\begin{array}{l}-0.046 \\
(0.034)\end{array}$ & $\begin{array}{l}-0.040 \\
(0.035)\end{array}$ & $\begin{array}{l}-0.043 \\
(0.035)\end{array}$ & $\begin{array}{l}-0.037 \\
(0.035)\end{array}$ & $\begin{array}{l}-0.032 \\
(0.035)\end{array}$ \\
\hline UNION & $\begin{array}{c}-0.872^{* *} \\
(0.126)\end{array}$ & $\begin{array}{c}-0.882^{* *} \\
(0.126)\end{array}$ & $\begin{array}{c}-0.876^{* *} \\
(0.126)\end{array}$ & $\begin{array}{c}-0.886^{* *} \\
(0.126)\end{array}$ & $\begin{array}{c}-0.889^{* *} \\
(0.126)\end{array}$ \\
\hline INDEPEND & $\begin{array}{c}0.427^{* *} \\
(0.130)\end{array}$ & $\begin{array}{c}0.425^{* *} \\
(0.130)\end{array}$ & $\begin{array}{c}0.424^{* *} \\
(0.130)\end{array}$ & $\begin{array}{c}0.423^{* *} \\
(0.130)\end{array}$ & $\begin{array}{l}0.432^{* *} \\
(0.131)\end{array}$ \\
\hline FOREING & $\begin{array}{c}0.442^{* *} \\
(0.170)\end{array}$ & $\begin{array}{c}0.446^{* *} \\
(0.170)\end{array}$ & $\begin{array}{c}0.439^{* *} \\
(0.170)\end{array}$ & $\begin{array}{c}0.443^{* *} \\
(0.170)\end{array}$ & $\begin{array}{c}0.436^{* *} \\
(0.170)\end{array}$ \\
\hline PUBLIC & $\begin{array}{c}-0.939^{* *} \\
(0.166)\end{array}$ & $\begin{array}{c}-0.938^{* *} \\
(0.166)\end{array}$ & $\begin{array}{c}-0.938^{* *} \\
(0.166)\end{array}$ & $\begin{array}{c}-0.936^{* *} \\
(0.166)\end{array}$ & $\begin{array}{c}-0.937^{* *} \\
(0.166)\end{array}$ \\
\hline$L O N G E V$ & $\begin{array}{l}-0.001 \\
(0.001)\end{array}$ & $\begin{array}{r}-0.001 \\
(0.001)\end{array}$ & $\begin{array}{l}-0.001 \\
(0.001)\end{array}$ & $\begin{array}{l}-0.001 \\
(0.001)\end{array}$ & $\begin{array}{r}-0.001 \\
(0.001)\end{array}$ \\
\hline $\begin{array}{c}\text { 1-digit Industry } \\
\text { Dummies }\end{array}$ & Yes & Yes & Yes & Yes & Yes \\
\hline $\begin{array}{c}\text { Percentages of } \\
\text { Workforce in each } \\
\text { Occupation }\end{array}$ & Yes & Yes & Yes & Yes & Yes \\
\hline $\begin{array}{c}\text { Number of } \\
\text { observations }\end{array}$ & 1602 & 1602 & 1602 & 1602 & 1602 \\
\hline$L-R$ test $\chi^{2}$ & $406.09^{* *}$ & $407.07^{* *}$ & $407.29^{* *}$ & $408.68^{* *}$ & $410.45^{* *}$ \\
\hline
\end{tabular}

Significant at the $10 \%$ level. ${ }^{* *}$ Significant at the $5 \%$ level 
Panel 3.2: Whether Managers Are Considered a Channel for Employees' Suggestions

\begin{tabular}{|c|c|c|c|c|c|}
\hline $\begin{array}{c}\text { Dep. Var.: } \\
\text { IMPRMGMT }\end{array}$ & Model I & Model II & $\underline{\underline{\text { Model III }}}$ & $\underline{\underline{\text { Model IV }}}$ & Model V \\
\hline PROPFEMG & $\begin{array}{l}0.336 \\
(0.269)\end{array}$ & $\begin{array}{l}0.585^{*} \\
(0.308)\end{array}$ & $\begin{array}{l}0.209 \\
(0.286)\end{array}$ & $\begin{array}{l}0.459 \\
(0.322)\end{array}$ & $\begin{array}{l}1.448^{* *} \\
(0.708)\end{array}$ \\
\hline PROPWOM & & $\begin{array}{c}-0.714^{*} \\
(0.412)\end{array}$ & & $\begin{array}{r}-0.718^{*} \\
(0.413)\end{array}$ & $\begin{array}{c}-0.372 \\
(0.465)\end{array}$ \\
\hline$F E M G \times W O M$ & & & & & $\begin{array}{c}-1.536 \\
(0.983)\end{array}$ \\
\hline RESPFEMG & & & $\begin{array}{l}0.193 \\
(0.142)\end{array}$ & $\begin{array}{l}0.193 \\
(0.142)\end{array}$ & $\begin{array}{l}0.196 \\
(0.142)\end{array}$ \\
\hline$N U M E M P S \times 10^{-3}$ & $\begin{array}{c}0.427^{* *} \\
(0.121)\end{array}$ & $\begin{array}{c}0.430^{* *} \\
(0.121)\end{array}$ & $\begin{array}{c}0.429^{* *} \\
(0.121)\end{array}$ & $\begin{array}{c}0.432^{* *} \\
(0.121)\end{array}$ & $\begin{array}{c}0.409^{* *} \\
(0.121)\end{array}$ \\
\hline$A V G A G E$ & $\begin{array}{l}-0.008 \\
(0.014)\end{array}$ & $\begin{array}{l}0.006 \\
(0.014)\end{array}$ & $\begin{array}{l}0.008 \\
(0.014)\end{array}$ & $\begin{array}{l}0.005 \\
(0.014)\end{array}$ & $\begin{array}{l}0.007 \\
(0.014)\end{array}$ \\
\hline$A V G E D U$ & $\begin{array}{l}0.052 \\
(0.048)\end{array}$ & $\begin{array}{l}0.039 \\
(0.049)\end{array}$ & $\begin{array}{l}0.047 \\
(0.048)\end{array}$ & $\begin{array}{l}0.034 \\
(0.049)\end{array}$ & $\begin{array}{l}0.025 \\
(0.049)\end{array}$ \\
\hline UNION & $\begin{array}{l}0.337^{*} \\
(0.174)\end{array}$ & $\begin{array}{l}0.371^{* *} \\
(0.176)\end{array}$ & $\begin{array}{l}0.347^{* *} \\
(0.175)\end{array}$ & $\begin{array}{l}0.381^{* *} \\
(0.176)\end{array}$ & $\begin{array}{c}0.386^{* *} \\
(0.176)\end{array}$ \\
\hline INDEPEND & $\begin{array}{c}-0.756^{* *} \\
(0.215)\end{array}$ & $\begin{array}{c}-0.741^{* *} \\
(0.215)\end{array}$ & $\begin{array}{c}-0.744^{* *} \\
(0.215)\end{array}$ & $\begin{array}{c}-0.730^{* *} \\
(0.215)\end{array}$ & $\begin{array}{c}-0.747^{* *} \\
(0.216)\end{array}$ \\
\hline FOREING & $\begin{array}{l}0.048 \\
(0.212)\end{array}$ & $\begin{array}{l}0.041 \\
(0.212)\end{array}$ & $\begin{array}{l}0.054 \\
(0.212)\end{array}$ & $\begin{array}{l}0.047 \\
(0.212)\end{array}$ & $\begin{array}{l}0.057 \\
(0.212)\end{array}$ \\
\hline PUBLIC & $\begin{array}{l}0.402 \\
(0.239)\end{array}$ & $\begin{array}{l}0.390 \\
(0.239)\end{array}$ & $\begin{array}{l}0.403^{*} \\
(0.239)\end{array}$ & $\begin{array}{l}0.392 \\
(0.239)\end{array}$ & $\begin{array}{l}0.394^{*} \\
(0.240)\end{array}$ \\
\hline$L O N G E V$ & $\begin{array}{l}0.001 \\
(0.002)\end{array}$ & $\begin{array}{l}0.001 \\
(0.002)\end{array}$ & $\begin{array}{l}0.002 \\
(0.002)\end{array}$ & $\begin{array}{l}0.001 \\
(0.002)\end{array}$ & $\begin{array}{l}0.001 \\
(0.002)\end{array}$ \\
\hline $\begin{array}{c}\text { 1-digit Industry } \\
\text { Dummies }\end{array}$ & Yes & Yes & Yes & Yes & Yes \\
\hline $\begin{array}{c}\text { Percentages of } \\
\text { Workforce in each } \\
\text { Occupation }\end{array}$ & Yes & Yes & Yes & Yes & Yes \\
\hline $\begin{array}{c}\text { Number of } \\
\text { observations }\end{array}$ & 1559 & 1559 & 1559 & 1559 & 1559 \\
\hline$L-R$ test $\chi^{2}$ & $232.56^{* *}$ & $235.61^{* *}$ & $234.40^{* *}$ & $237.46^{* *}$ & $239.93^{* *}$ \\
\hline
\end{tabular}

* Significant at the $10 \%$ level. ${ }^{* *}$ Significant at the $5 \%$ level 
Table 4: Effect of the proportion of women at management on the degree of democracy in managerial decision-making.(Ordered) Logit estimates with standard errors in parentheses.

Panel 4.1: Extent to Which Interviewed Manager Thinks Those at Top Are the Best Placed to Make Decisions

\begin{tabular}{|c|c|c|c|c|c|}
\hline $\begin{array}{c}\text { Dep. Var.: } \\
\text { DECSATOP }\end{array}$ & Model I & $\underline{\underline{\text { Model II }}}$ & $\underline{\underline{\text { Model III }}}$ & $\underline{\underline{\text { Model IV }}}$ & Model V \\
\hline PROPFEMG & $\begin{array}{l}-0.149 \\
(0.185)\end{array}$ & $\begin{array}{r}-0.161 \\
(0.205)\end{array}$ & $\begin{array}{l}0.092 \\
(0.199)\end{array}$ & $\begin{array}{l}0.090 \\
(0.219)\end{array}$ & $\begin{array}{r}-0.445 \\
(0.521)\end{array}$ \\
\hline PROPWOM & & $\begin{array}{l}0.037 \\
(0.282)\end{array}$ & & $\begin{array}{l}-0.009 \\
(0.282)\end{array}$ & $\begin{array}{c}-0.162 \\
(0.320)\end{array}$ \\
\hline$F E M G \times W O M$ & & & & & $\begin{array}{l}0.774 \\
(0.686)\end{array}$ \\
\hline RESPFEMG & & & $\begin{array}{c}-0.350^{* *} \\
(0.104)\end{array}$ & $\begin{array}{c}-0.350^{* *} \\
(0.105)\end{array}$ & $\begin{array}{c}-0.353^{* *} \\
(0.105)\end{array}$ \\
\hline$N U M E M P S \times 10^{-3}$ & $\begin{array}{l}-0.003 \\
(0.079)\end{array}$ & $\begin{array}{l}-0.003 \\
(0.079)\end{array}$ & $\begin{array}{c}-0.004 \\
(0.079)\end{array}$ & $\begin{array}{l}-0.004 \\
(0.079)\end{array}$ & $\begin{array}{l}0.005 \\
(0.081)\end{array}$ \\
\hline$A V G A G E$ & $\begin{array}{l}-0.009 \\
(0.010)\end{array}$ & $\begin{array}{c}-0.009 \\
(0.010)\end{array}$ & $\begin{array}{l}-0.007 \\
(0.010)\end{array}$ & $\begin{array}{c}-0.008 \\
(0.010)\end{array}$ & $\begin{array}{c}-0.008 \\
(0.010)\end{array}$ \\
\hline$A V G E D U$ & $\begin{array}{l}-0.004 \\
(0.034)\end{array}$ & $\begin{array}{l}-0.003 \\
(0.034)\end{array}$ & $\begin{array}{l}0.005 \\
(0.034)\end{array}$ & $\begin{array}{l}0.005 \\
(0.034)\end{array}$ & $\begin{array}{l}0.009 \\
(0.034)\end{array}$ \\
\hline UNION & $\begin{array}{l}-0.156 \\
(0.124)\end{array}$ & $\begin{array}{r}-0.157 \\
(0.124)\end{array}$ & $\begin{array}{l}-0.171 \\
(0.124)\end{array}$ & $\begin{array}{l}-0.172 \\
(0.124)\end{array}$ & $\begin{array}{c}-0.174 \\
(0.124)\end{array}$ \\
\hline INDEPEND & $\begin{array}{c}0.645^{* *} \\
(0.128)\end{array}$ & $\begin{array}{c}0.645^{* *} \\
(0.128)\end{array}$ & $\begin{array}{c}0.635^{* *} \\
(0.128)\end{array}$ & $\begin{array}{c}0.635^{* *} \\
(0.128)\end{array}$ & $\begin{array}{c}0.642^{* * *} \\
(0.129)\end{array}$ \\
\hline FOREING & $\begin{array}{l}0.087 \\
(0.168)\end{array}$ & $\begin{array}{l}0.088 \\
(0.168)\end{array}$ & $\begin{array}{l}0.089 \\
(0.168)\end{array}$ & $\begin{array}{l}0.089 \\
(0.168)\end{array}$ & $\begin{array}{l}0.084 \\
(0.168)\end{array}$ \\
\hline PUBLIC & $\begin{array}{l}-0.015 \\
(0.162)\end{array}$ & $\begin{array}{r}-0.015 \\
(0.162)\end{array}$ & $\begin{array}{l}-0.017 \\
(0.162)\end{array}$ & $\begin{array}{r}-0.017 \\
(0.162)\end{array}$ & $\begin{array}{c}-0.016 \\
(0.162)\end{array}$ \\
\hline LONGEV & $\begin{array}{c}0.003^{* *} \\
(0.001)\end{array}$ & $\begin{array}{c}0.003^{* *} \\
(0.001)\end{array}$ & $\begin{array}{c}0.002^{* *} \\
(0.001)\end{array}$ & $\begin{array}{c}0.002^{* *} \\
(0.001)\end{array}$ & $\begin{array}{l}0.002^{* *} \\
(0.001)\end{array}$ \\
\hline $\begin{array}{c}\text { 1-digit Industry } \\
\text { Dummies }\end{array}$ & Yes & Yes & Yes & Yes & Yes \\
\hline $\begin{array}{c}\text { Percentages of } \\
\text { Workforce in each } \\
\text { Occupation }\end{array}$ & Yes & Yes & Yes & Yes & Yes \\
\hline $\begin{array}{c}\text { Number of } \\
\text { observations }\end{array}$ & 1602 & 1602 & 1602 & 1602 & 1602 \\
\hline$L-R$ test $\chi^{2}$ & $84.41^{* *}$ & $84.42^{* *}$ & $95.64^{* *}$ & $95.64^{* *}$ & $96.92^{* *}$ \\
\hline
\end{tabular}

* Significant at the $10 \%$ level. ${ }^{* *}$ Significant at the $5 \%$ level 
Panel 4.2: Extent to Which Managers Discuss Changes to Be Done at the Workplace with Employees before Introducing Them

\begin{tabular}{|c|c|c|c|c|c|}
\hline $\begin{array}{c}\text { Dep. Var.: } \\
\text { EMPSCHAN }\end{array}$ & $\underline{\underline{\text { Model I }}}$ & Model II & $\underline{\underline{\text { Model III }}}$ & Model IV & $\underline{\text { Model V }}$ \\
\hline PROPFEMG & $\begin{array}{l}0.347^{*} \\
(0.191)\end{array}$ & $\begin{array}{l}0.173 \\
(0.212)\end{array}$ & $\begin{array}{l}0.347^{*} \\
(0.204)\end{array}$ & $\begin{array}{l}0.172 \\
(0.224)\end{array}$ & $\begin{array}{l}-0.847 \\
(0.530)\end{array}$ \\
\hline PROPWOM & & $\begin{array}{c}0.569^{*} \\
(0.304)\end{array}$ & & $\begin{array}{l}0.569^{*} \\
(0.304)\end{array}$ & $\begin{array}{l}0.225 \\
(0.344)\end{array}$ \\
\hline$F E M G \times W O M$ & & & & & $\begin{array}{c}1.488^{* * *} \\
(0.702)\end{array}$ \\
\hline RESPFEMG & & & $\begin{array}{l}0.001 \\
(0.109)\end{array}$ & $\begin{array}{l}0.002 \\
(0.109)\end{array}$ & $\begin{array}{c}-0.004 \\
(0.109)\end{array}$ \\
\hline$N U M E M P S \times 10^{-3}$ & $\begin{array}{l}0.055 \\
(0.077)\end{array}$ & $\begin{array}{l}0.058 \\
(0.077)\end{array}$ & $\begin{array}{l}0.055 \\
(0.077)\end{array}$ & $\begin{array}{l}0.058 \\
(0.077)\end{array}$ & $\begin{array}{l}0.074 \\
(0.078)\end{array}$ \\
\hline$A V G A G E$ & $\begin{array}{l}0.004 \\
(0.010)\end{array}$ & $\begin{array}{l}0.005 \\
(0.010)\end{array}$ & $\begin{array}{l}0.004 \\
(0.010)\end{array}$ & $\begin{array}{l}0.006 \\
(0.010)\end{array}$ & $\begin{array}{l}0.005 \\
(0.010)\end{array}$ \\
\hline$A V G E D U$ & $\begin{array}{l}-0.022 \\
(0.035)\end{array}$ & $\begin{array}{l}-0.012 \\
(0.036)\end{array}$ & $\begin{array}{l}-0.022 \\
(0.035)\end{array}$ & $\begin{array}{r}-0.012 \\
(0.036)\end{array}$ & $\begin{array}{l}-0.004 \\
(0.036)\end{array}$ \\
\hline UNION & $\begin{array}{l}0.620^{* * *} \\
(0.131)\end{array}$ & $\begin{array}{l}0.607^{* *} \\
(0.132)\end{array}$ & $\begin{array}{c}0.620^{* * *} \\
(0.131)\end{array}$ & $\begin{array}{c}0.607^{* * *} \\
(0.132)\end{array}$ & $\begin{array}{c}0.602^{* * *} \\
(0.132)\end{array}$ \\
\hline INDEPEND & $\begin{array}{l}-0.168 \\
(0.133)\end{array}$ & $\begin{array}{l}-0.169 \\
(0.133)\end{array}$ & $\begin{array}{l}-0.168 \\
(0.133)\end{array}$ & $\begin{array}{c}-0.168 \\
(0.133)\end{array}$ & $\begin{array}{l}-0.158 \\
(0.133)\end{array}$ \\
\hline FOREING & $\begin{array}{l}-0.023 \\
(0.172)\end{array}$ & $\begin{array}{l}-0.011 \\
(0.173)\end{array}$ & $\begin{array}{r}-0.023 \\
(0.172)\end{array}$ & $\begin{array}{c}-0.011 \\
(0.173)\end{array}$ & $\begin{array}{l}-0.024 \\
(0.173)\end{array}$ \\
\hline PUBLIC & $\begin{array}{r}-0.013 \\
(0.172)\end{array}$ & $\begin{array}{l}-0.004 \\
(0.172)\end{array}$ & $\begin{array}{r}-0.013 \\
(0.172)\end{array}$ & $\begin{array}{c}-0.004 \\
(0.172)\end{array}$ & $\begin{array}{l}0.001 \\
(0.173)\end{array}$ \\
\hline LONGEV & $\begin{array}{l}0.001 \\
(0.001)\end{array}$ & $\begin{array}{l}0.001 \\
(0.001)\end{array}$ & $\begin{array}{l}0.001 \\
(0.001)\end{array}$ & $\begin{array}{l}0.001 \\
(0.001)\end{array}$ & $\begin{array}{l}0.001 \\
(0.001)\end{array}$ \\
\hline $\begin{array}{l}\text { 1-digit Industry } \\
\text { Dummies }\end{array}$ & Yes & Yes & Yes & Yes & Yes \\
\hline $\begin{array}{l}\text { Percentages of } \\
\text { Workforce in each } \\
\text { Occupation }\end{array}$ & Yes & Yes & Yes & Yes & Yes \\
\hline $\begin{array}{c}\text { Number of } \\
\text { observations }\end{array}$ & 1602 & 1602 & 1602 & 1602 & 1602 \\
\hline$L-R$ test $\chi^{2}$ & $120.20^{* *}$ & $123.72^{* *}$ & $120.20^{* *}$ & $123.72^{* *}$ & $128.21^{* *}$ \\
\hline
\end{tabular}

Significant at the $10 \%$ level. ${ }^{* * *}$ Significant at the $5 \%$ level 
Panel 4.3: Extent to which Decisions at Workplace are Made without Being First Discussed with Employees

\begin{tabular}{|c|c|c|c|c|c|}
\hline $\begin{array}{c}\text { Dep. Var.: } \\
\text { EMPSNOCO }\end{array}$ & $\underline{\underline{\text { Model I }}}$ & $\underline{\underline{\text { Model III }}}$ & $\underline{\underline{\text { Model III }}}$ & Model IV & Model V \\
\hline PROPFEMG & $\begin{array}{c}-0.481^{* *} \\
(0.192)\end{array}$ & $\begin{array}{c}-0.427^{* *} \\
(0.213)\end{array}$ & $\begin{array}{c}-0.508^{* *} \\
(0.206)\end{array}$ & $\begin{array}{c}-0.454^{* *} \\
(0.226)\end{array}$ & $\begin{array}{l}0.987^{*} \\
(0.534)\end{array}$ \\
\hline PROPWOM & & $\begin{array}{l}-0.169 \\
(0.297)\end{array}$ & & $\begin{array}{l}-0.168 \\
(0.297)\end{array}$ & $\begin{array}{l}0.293 \\
(0.335)\end{array}$ \\
\hline$F E M G \times W O M$ & & & & & $\begin{array}{c}-2.102^{* *} \\
(0.707)\end{array}$ \\
\hline RESPFEMG & & & $\begin{array}{l}0.040 \\
(0.109)\end{array}$ & $\begin{array}{l}0.039 \\
(0.109)\end{array}$ & $\begin{array}{l}0.046 \\
(0.109)\end{array}$ \\
\hline NUMEMPS $\times 10^{-3}$ & $\begin{array}{l}-0.083 \\
(0.082)\end{array}$ & $\begin{array}{l}-0.084 \\
(0.082)\end{array}$ & $\begin{array}{l}-0.083 \\
(0.082)\end{array}$ & $\begin{array}{l}-0.084 \\
(0.082)\end{array}$ & $\begin{array}{l}-0.110 \\
(0.083)\end{array}$ \\
\hline$A V G A G E$ & $\begin{array}{l}-0.013 \\
(0.010)\end{array}$ & $\begin{array}{l}-0.014 \\
(0.010)\end{array}$ & $\begin{array}{l}-0.013 \\
(0.010)\end{array}$ & $\begin{array}{l}-0.014 \\
(0.010)\end{array}$ & $\begin{array}{l}-0.013 \\
(0.010)\end{array}$ \\
\hline$A V G E D U$ & $\begin{array}{l}-0.030 \\
(0.035)\end{array}$ & $\begin{array}{l}-0.033 \\
(0.036)\end{array}$ & $\begin{array}{l}-0.031 \\
(0.035)\end{array}$ & $\begin{array}{l}-0.034 \\
(0.036)\end{array}$ & $\begin{array}{l}-0.048 \\
(0.036)\end{array}$ \\
\hline UNION & $\begin{array}{l}-0.422^{* *} \\
(0.130)\end{array}$ & $\begin{array}{c}-0.416^{* *} \\
(0.131)\end{array}$ & $\begin{array}{c}-0.421^{* *} \\
(0.130)\end{array}$ & $\begin{array}{c}-0.416^{* *} \\
(0.131)\end{array}$ & $\begin{array}{c}-0.408^{* *} \\
(0.131)\end{array}$ \\
\hline INDEPEND & $\begin{array}{c}0.542^{* *} \\
(0.133)\end{array}$ & $\begin{array}{c}0.542^{* *} \\
(0.133)\end{array}$ & $\begin{array}{c}0.544^{* * *} \\
(0.133)\end{array}$ & $\begin{array}{c}0.544^{* *} \\
(0.133)\end{array}$ & $\begin{array}{l}0.532^{* *} \\
(0.134)\end{array}$ \\
\hline FOREING & $\begin{array}{l}0.315^{*} \\
(0.173)\end{array}$ & $\begin{array}{l}0.311^{*} \\
(0.174)\end{array}$ & $\begin{array}{l}0.316^{*} \\
(0.173)\end{array}$ & $\begin{array}{l}0.313^{*} \\
(0.174)\end{array}$ & $\begin{array}{l}0.329^{*} \\
(0.174)\end{array}$ \\
\hline PUBLIC & $\begin{array}{l}-0.160 \\
(0.172)\end{array}$ & $\begin{array}{l}-0.164 \\
(0.172)\end{array}$ & $\begin{array}{l}-0.159 \\
(0.172)\end{array}$ & $\begin{array}{l}-0.162 \\
(0.172)\end{array}$ & $\begin{array}{l}-0.173 \\
(0.172)\end{array}$ \\
\hline LONGEV & $\begin{array}{r}-0.002^{*} \\
(0.001)\end{array}$ & $\begin{array}{l}0.002^{*} \\
(0.001)\end{array}$ & $\begin{array}{r}-0.002^{*} \\
(0.001)\end{array}$ & $\begin{array}{l}0.002^{*} \\
(0.001)\end{array}$ & $\begin{array}{l}0.002^{*} \\
(0.001)\end{array}$ \\
\hline $\begin{array}{l}\text { 1-digit Industry } \\
\text { Dummies }\end{array}$ & Yes & Yes & Yes & Yes & Yes \\
\hline $\begin{array}{l}\text { Percentages of } \\
\text { Workforce in each } \\
\text { Occupation }\end{array}$ & Yes & Yes & Yes & Yes & Yes \\
\hline $\begin{array}{l}\text { Number of } \\
\text { observations }\end{array}$ & 1602 & 1602 & 1602 & 1602 & 1602 \\
\hline$L-R$ test $\chi^{2}$ & $192.35^{* *}$ & $192.67^{* * *}$ & $192.48^{* * *}$ & $192.80^{* * *}$ & $201.68^{* *}$ \\
\hline
\end{tabular}

All regressions include 1-digit SIC industrial dummies and six controls of workforce composition. Significant at the $10 \%$ level. ${ }^{* *}$ Significant at the $5 \%$ level 
Panel 4.4: Whether Managers Set Establishment Targets in Consultation with Employees

\begin{tabular}{|c|c|c|c|c|c|}
\hline $\begin{array}{l}\text { Dep. Var.: } \\
\text { CONSTARG }\end{array}$ & Model I & $\underline{\underline{\text { Model II }}}$ & $\underline{\underline{\text { Model III }}}$ & Model IV & $\underline{\underline{M o d e l} V}$ \\
\hline PROPFEMG & $\begin{array}{c}-0.124 \\
(0.225)\end{array}$ & $\begin{array}{r}-0.169 \\
(0.252)\end{array}$ & $\begin{array}{l}-0.146 \\
(0.241)\end{array}$ & $\begin{array}{l}0.104 \\
(0.267)\end{array}$ & $\begin{array}{c}-0.753 \\
(0.641)\end{array}$ \\
\hline PROPWOM & & $\begin{array}{l}0.137 \\
(0.342)\end{array}$ & & $\begin{array}{l}0.127 \\
(0.343)\end{array}$ & $\begin{array}{c}-0.139 \\
(0.387)\end{array}$ \\
\hline$F E M G \times W O M$ & & & & & $\begin{array}{l}1.248 \\
(0.846)\end{array}$ \\
\hline RESPFEMG & & & $\begin{array}{c}-0.388^{* *} \\
(0.125)\end{array}$ & $\begin{array}{c}-0.387^{* *} \\
(0.125)\end{array}$ & $\begin{array}{c}-0.390^{* *} \\
(0.125)\end{array}$ \\
\hline$N U M E M P S \times 10^{-3}$ & $\begin{array}{c}-0.198^{*} \\
(0.112)\end{array}$ & $\begin{array}{c}-0.197^{*} \\
(0.112)\end{array}$ & $\begin{array}{c}-0.199^{*} \\
(0.112)\end{array}$ & $\begin{array}{c}-0.198^{*} \\
(0.112)\end{array}$ & $\begin{array}{c}-0.181 \\
(0.111)\end{array}$ \\
\hline$A V G A G E$ & $\begin{array}{l}0.013 \\
(0.012)\end{array}$ & $\begin{array}{l}0.013 \\
(0.012)\end{array}$ & $\begin{array}{l}0.014 \\
(0.012)\end{array}$ & $\begin{array}{l}0.015 \\
(0.012)\end{array}$ & $\begin{array}{l}0.014 \\
(0.012)\end{array}$ \\
\hline$A V G E D U$ & $\begin{array}{r}-0.070^{*} \\
(0.041)\end{array}$ & $\begin{array}{l}-0.067 \\
(0.041)\end{array}$ & $\begin{array}{l}-0.061 \\
(0.041)\end{array}$ & $\begin{array}{c}-0.058 \\
(0.042)\end{array}$ & $\begin{array}{c}-0.050 \\
(0.042)\end{array}$ \\
\hline UNION & $\begin{array}{c}-0.291^{* *} \\
(0.147)\end{array}$ & $\begin{array}{c}-0.295^{* *} \\
(0.147)\end{array}$ & $\begin{array}{c}-0.304^{* *} \\
(0.148)\end{array}$ & $\begin{array}{c}-0.307^{* *} \\
(0.148)\end{array}$ & $\begin{array}{c}-0.308^{* *} \\
(0.148)\end{array}$ \\
\hline INDEPEND & $\begin{array}{l}0.000 \\
(0.157)\end{array}$ & $\begin{array}{l}0.001 \\
(0.157)\end{array}$ & $\begin{array}{l}-0.016 \\
(0.158)\end{array}$ & $\begin{array}{l}0.017 \\
(0.158)\end{array}$ & $\begin{array}{c}-0.005 \\
(0.158)\end{array}$ \\
\hline FOREING & $\begin{array}{l}-0.179 \\
(0.193)\end{array}$ & $\begin{array}{c}-0.176 \\
(0.193)\end{array}$ & $\begin{array}{l}-0.189 \\
(0.193)\end{array}$ & $\begin{array}{l}-0.187 \\
(0.193)\end{array}$ & $\begin{array}{c}-0.192 \\
(0.194)\end{array}$ \\
\hline PUBLIC & $\begin{array}{l}0.212 \\
(0.195)\end{array}$ & $\begin{array}{l}0.212 \\
(0.195)\end{array}$ & $\begin{array}{l}0.210 \\
(0.195)\end{array}$ & $\begin{array}{l}0.211 \\
(0.195)\end{array}$ & $\begin{array}{l}0.208 \\
(0.195)\end{array}$ \\
\hline$L O N G E V$ & $\begin{array}{l}-0.001 \\
(0.001)\end{array}$ & $\begin{array}{l}-0.001 \\
(0.001)\end{array}$ & $\begin{array}{l}-0.001 \\
(0.001)\end{array}$ & $\begin{array}{l}-0.001 \\
(0.001)\end{array}$ & $\begin{array}{c}-0.001 \\
(0.001)\end{array}$ \\
\hline $\begin{array}{c}\text { 1-digit Industry } \\
\text { Dummies }\end{array}$ & Yes & Yes & Yes & Yes & Yes \\
\hline $\begin{array}{c}\text { Percentages of } \\
\text { Workforce in each } \\
\text { Occupation }\end{array}$ & Yes & Yes & Yes & Yes & Yes \\
\hline $\begin{array}{c}\text { Number of } \\
\text { observations }\end{array}$ & 1455 & 1455 & 1455 & 1455 & 1455 \\
\hline$L-R$ test $\chi^{2}$ & $85.18^{* *}$ & $85.34^{* *}$ & $94.88^{* *}$ & $95.02^{* *}$ & $97.22^{* *}$ \\
\hline
\end{tabular}

All regressions include 1-digit SIC industrial dummies and six controls of workforce composition. Significant at the $10 \%$ level. ${ }^{* *}$ Significant at the $5 \%$ level 
Table 5: Effect of the proportion of women at management on the degree to which managementsubordinate relationships are interactive. (Ordered) Logit estimates with standard errors in parentheses.

Panel 5.1: Proportion of Time in Briefing Meetings Given to Employees

\begin{tabular}{|c|c|c|c|c|c|}
\hline $\begin{array}{l}\text { Dep. Var.: } \\
\text { PARTBRIE }\end{array}$ & Model I & $\underline{\underline{\text { Model III }}}$ & $\underline{\underline{\text { Model III }}}$ & $\underline{\text { Model IV }}$ & $\underline{\text { Model V }}$ \\
\hline PROPFEMG & $\begin{array}{c}0.458^{* *} \\
(0.192)\end{array}$ & $\begin{array}{c}0.435^{* *} \\
(0.212)\end{array}$ & $\begin{array}{c}0.663^{* *} \\
(0.206)\end{array}$ & $\begin{array}{c}0.646^{* *} \\
(0.226)\end{array}$ & $\begin{array}{l}0.565 \\
(0.531)\end{array}$ \\
\hline PROPWOM & & $\begin{array}{l}0.075 \\
(0.295)\end{array}$ & & $\begin{array}{l}0.054 \\
(0.295)\end{array}$ & $\begin{array}{l}0.028 \\
(0.333)\end{array}$ \\
\hline$F E M G \times W O M$ & & & & & $\begin{array}{l}0.120 \\
(0.705)\end{array}$ \\
\hline RESPFEMG & & & $\begin{array}{c}-0.296^{* *} \\
(0.107)\end{array}$ & $\begin{array}{c}-0.295^{* *} \\
(0.107)\end{array}$ & $\begin{array}{c}-0.296^{* *} \\
(0.107)\end{array}$ \\
\hline$N U M E M P S \times 10^{-3}$ & $\begin{array}{r}-0.020 \\
(0.069)\end{array}$ & $\begin{array}{l}-0.020 \\
(0.069)\end{array}$ & $\begin{array}{l}-0.022 \\
(0.069)\end{array}$ & $\begin{array}{l}-0.022 \\
(0.069)\end{array}$ & $\begin{array}{l}-0.021 \\
(0.069)\end{array}$ \\
\hline$A V G A G E$ & $\begin{array}{l}0.005 \\
(0.010)\end{array}$ & $\begin{array}{l}0.005 \\
(0.010)\end{array}$ & $\begin{array}{l}0.006 \\
(0.010)\end{array}$ & $\begin{array}{l}0.006 \\
(0.010)\end{array}$ & $\begin{array}{l}0.006 \\
(0.010)\end{array}$ \\
\hline$A V G E D U$ & $\begin{array}{l}0.002 \\
(0.035)\end{array}$ & $\begin{array}{l}0.004 \\
(0.035)\end{array}$ & $\begin{array}{l}0.009 \\
(0.035)\end{array}$ & $\begin{array}{l}0.010 \\
(0.035)\end{array}$ & $\begin{array}{l}0.011 \\
(0.035)\end{array}$ \\
\hline UNION & $\begin{array}{c}0.325^{* *} \\
(0.128)\end{array}$ & $\begin{array}{c}0.322^{* * *} \\
(0.128)\end{array}$ & $\begin{array}{c}0.326^{* *} \\
(0.128)\end{array}$ & $\begin{array}{c}0.324^{* *} \\
(0.128)\end{array}$ & $\begin{array}{c}0.324^{* *} \\
(0.128)\end{array}$ \\
\hline INDEPEND & $\begin{array}{c}-0.268^{* *} \\
(0.132)\end{array}$ & $\begin{array}{c}-0.269^{* *} \\
(0.132)\end{array}$ & $\begin{array}{c}-0.285^{* *} \\
(0.132)\end{array}$ & $\begin{array}{c}-0.285^{* *} \\
(0.132)\end{array}$ & $\begin{array}{c}-0.284^{* *} \\
(0.132)\end{array}$ \\
\hline FOREING & $\begin{array}{l}-0.007 \\
(0.169)\end{array}$ & $\begin{array}{l}0.008 \\
(0.169)\end{array}$ & $\begin{array}{l}-0.002 \\
(0.169)\end{array}$ & $\begin{array}{l}-0.001 \\
(0.169)\end{array}$ & $\begin{array}{l}-0.002 \\
(0.169)\end{array}$ \\
\hline PUBLIC & $\begin{array}{c}-0.358^{* *} \\
(0.171)\end{array}$ & $\begin{array}{c}-0.357^{* *} \\
(0.171)\end{array}$ & $\begin{array}{c}-0.366^{* *} \\
(0.171)\end{array}$ & $\begin{array}{c}-0.365^{* *} \\
(0.171)\end{array}$ & $\begin{array}{c}-0.365^{* *} \\
(0.171)\end{array}$ \\
\hline$L O N G E V$ & $\begin{array}{l}-0.001 \\
(0.001)\end{array}$ & $\begin{array}{l}-0.001 \\
(0.001)\end{array}$ & $\begin{array}{l}-0.001 \\
(0.001)\end{array}$ & $\begin{array}{l}-0.001 \\
(0.001)\end{array}$ & $\begin{array}{l}-0.001 \\
(0.001)\end{array}$ \\
\hline $\begin{array}{l}\text { 1-digit Industry } \\
\text { Dummies }\end{array}$ & Yes & Yes & Yes & Yes & Yes \\
\hline $\begin{array}{l}\text { Percentages of } \\
\text { Workforce in each } \\
\text { Occupation }\end{array}$ & Yes & Yes & Yes & Yes & Yes \\
\hline $\begin{array}{l}\text { Number of } \\
\text { observations }\end{array}$ & 1580 & 1580 & 1580 & 1580 & 1580 \\
\hline$L-R$ test $\chi^{2}$ & $83.45^{* *}$ & $83.51^{* *}$ & $91.17^{* * *}$ & $91.20^{* *}$ & $91.23^{* *}$ \\
\hline
\end{tabular}

Significant at the $10 \%$ level. ${ }^{* *}$ Significant at the $5 \%$ level 
Panel 5.2: Whether Managers Use Performance Appraisals to Give Feedback to Employees, Discuss Career Moves and Set Personal Objectives

\begin{tabular}{|c|c|c|c|c|c|}
\hline $\begin{array}{l}\text { Dep. Var.: } \\
\text { DISCUSS }\end{array}$ & Model I & $\underline{\underline{\text { Model II }}}$ & $\underline{\underline{\text { Model III }}}$ & $\underline{\underline{\text { Model IV }}}$ & $\underline{\underline{\text { Model V }}}$ \\
\hline PROPFEMG & $\begin{array}{c}0.715^{* * *} \\
(0.263)\end{array}$ & $\begin{array}{l}0.533^{*} \\
(0.294)\end{array}$ & $\begin{array}{c}0.728^{* *} \\
(0.281)\end{array}$ & $\begin{array}{l}0.544^{*} \\
(0.309)\end{array}$ & $\begin{array}{l}1.322^{*} \\
(0.725)\end{array}$ \\
\hline PROPWOM & & $\begin{array}{l}0.553 \\
(0.387)\end{array}$ & & $\begin{array}{l}0.553 \\
(0.388)\end{array}$ & $\begin{array}{l}0.790^{*} \\
(0.437)\end{array}$ \\
\hline$F E M G \times W O M$ & & & & & $\begin{array}{l}-1.135 \\
(0.949)\end{array}$ \\
\hline RESPFEMG & & & $\begin{array}{l}-0.018 \\
(0.146)\end{array}$ & $\begin{array}{l}-0.017 \\
(0.146)\end{array}$ & $\begin{array}{l}-0.013 \\
(0.147)\end{array}$ \\
\hline$N U M E M P S \times 10^{-3}$ & $\begin{array}{c}0.588^{* *} \\
(0.220)\end{array}$ & $\begin{array}{c}0.590^{* * *} \\
(0.220)\end{array}$ & $\begin{array}{c}0.589^{* *} \\
(0.220)\end{array}$ & $\begin{array}{c}0.591^{* *} \\
(0.220)\end{array}$ & $\begin{array}{c}0.564^{* *} \\
(0.220)\end{array}$ \\
\hline$A V G A G E$ & $\begin{array}{c}-0.029^{* *} \\
(0.013)\end{array}$ & $\begin{array}{c}-0.028^{* *} \\
(0.013)\end{array}$ & $\begin{array}{c}-0.029^{* *} \\
(0.013)\end{array}$ & $\begin{array}{c}-0.028^{* * *} \\
(0.013)\end{array}$ & $\begin{array}{c}-0.028^{* *} \\
(0.013)\end{array}$ \\
\hline$A V G E D U$ & $\begin{array}{c}0.155^{* *} \\
(0.049)\end{array}$ & $\begin{array}{l}0.165^{* *} \\
(0.049)\end{array}$ & $\begin{array}{c}0.155^{* *} \\
(0.049)\end{array}$ & $\begin{array}{c}0.165^{* *} \\
(0.050)\end{array}$ & $\begin{array}{l}0.159^{* *} \\
(0.050)\end{array}$ \\
\hline UNION & $\begin{array}{c}0.345^{* *} \\
(0.171)\end{array}$ & $\begin{array}{l}0.331^{*} \\
(0.171)\end{array}$ & $\begin{array}{c}0.345^{* *} \\
(0.171)\end{array}$ & $\begin{array}{l}0.330^{*} \\
(0.171)\end{array}$ & $\begin{array}{c}0.337^{* * *} \\
(0.171)\end{array}$ \\
\hline INDEPEND & $\begin{array}{c}-0.854^{* *} \\
(0.163)\end{array}$ & $\begin{array}{c}-0.858^{* *} \\
(0.163)\end{array}$ & $\begin{array}{c}-0.855^{* *} \\
(0.163)\end{array}$ & $\begin{array}{c}-0.859^{* * *} \\
(0.163)\end{array}$ & $\begin{array}{c}-0.870^{* *} \\
(0.164)\end{array}$ \\
\hline FOREING & $\begin{array}{c}0.864^{* *} \\
(0.289)\end{array}$ & $\begin{array}{c}0.871^{* *} \\
(0.289)\end{array}$ & $\begin{array}{c}0.864^{* *} \\
(0.289)\end{array}$ & $\begin{array}{c}0.871^{* *} \\
(0.289)\end{array}$ & $\begin{array}{l}0.878^{* * *} \\
(0.289)\end{array}$ \\
\hline PUBLIC & $\begin{array}{c}-0.678^{* *} \\
(0.222)\end{array}$ & $\begin{array}{c}-0.672^{* *} \\
(0.222)\end{array}$ & $\begin{array}{c}-0.678^{* *} \\
(0.222)\end{array}$ & $\begin{array}{c}-0.672^{* *} \\
(0.222)\end{array}$ & $\begin{array}{c}-0.674^{* *} \\
(0.222)\end{array}$ \\
\hline LONGEV & $\begin{array}{l}0.001 \\
(0.002)\end{array}$ & $\begin{array}{l}0.001 \\
(0.002)\end{array}$ & $\begin{array}{l}0.001 \\
(0.002)\end{array}$ & $\begin{array}{l}0.001 \\
(0.002)\end{array}$ & $\begin{array}{l}0.001 \\
(0.002)\end{array}$ \\
\hline $\begin{array}{l}\text { 1-digit Industry } \\
\text { Dummies }\end{array}$ & Yes & Yes & Yes & Yes & Yes \\
\hline $\begin{array}{l}\text { Percentages of } \\
\text { Workforce in each } \\
\text { Occupation }\end{array}$ & Yes & Yes & Yes & Yes & Yes \\
\hline $\begin{array}{l}\text { Number of } \\
\text { observations }\end{array}$ & 1601 & 1601 & 1601 & 1601 & 1601 \\
\hline$L-R$ test $\chi^{2}$ & $216,00^{* *}$ & $218.05^{* *}$ & $216.01^{* *}$ & $218.06^{* *}$ & $219.50^{* *}$ \\
\hline
\end{tabular}

Significant at the $10 \%$ level. ${ }^{* *}$ Significant at the $5 \%$ level. 
Table 6: Effect of the proportion of women at management on the application of different schemes of payment by results. Logit estimates with standard errors in parentheses.

Panel 6.1: Whether Employees Receive Profit-Related Payment

\begin{tabular}{|c|c|c|c|c|c|}
\hline $\begin{array}{l}\text { Dep. Var.: } \\
\text { PROFREL }\end{array}$ & $\underline{\underline{\text { Model I }}}$ & Model II & $\underline{\underline{\text { Model III }}}$ & $\underline{\underline{\text { Model IV }}}$ & $\underline{\underline{\text { Model V }}}$ \\
\hline PROPFEMG & $\begin{array}{l}0.056 \\
(0.273)\end{array}$ & $\begin{array}{l}0.266 \\
(0.310)\end{array}$ & $\begin{array}{c}-0.028 \\
(0.287)\end{array}$ & $\begin{array}{l}0.182 \\
(0.322)\end{array}$ & $\begin{array}{r}-0.753 \\
(0.713)\end{array}$ \\
\hline PROPWOM & & $\begin{array}{c}-0.557 \\
(0.385)\end{array}$ & & $\begin{array}{c}-0.561 \\
(0.386)\end{array}$ & $\begin{array}{c}-0.868^{* *} \\
(0.440)\end{array}$ \\
\hline$F E M G \times W O M$ & & & & & $\begin{array}{l}1.444 \\
(0.985)\end{array}$ \\
\hline RESPFEMG & & & $\begin{array}{l}0.132 \\
(0.142)\end{array}$ & $\begin{array}{l}0.135 \\
(0.143)\end{array}$ & $\begin{array}{l}0.134 \\
(0.142)\end{array}$ \\
\hline NUMEMPS $\times 10^{-3}$ & $\begin{array}{l}0.055 \\
(0.103)\end{array}$ & $\begin{array}{l}0.054 \\
(0.104)\end{array}$ & $\begin{array}{l}0.056 \\
(0.103)\end{array}$ & $\begin{array}{l}0.055 \\
(0.104)\end{array}$ & $\begin{array}{l}0.065 \\
(0.105)\end{array}$ \\
\hline$A V G A G E$ & $\begin{array}{l}0.002 \\
(0.013)\end{array}$ & $\begin{array}{l}0.000 \\
(0.013)\end{array}$ & $\begin{array}{l}0.001 \\
(0.013)\end{array}$ & $\begin{array}{l}-0.00 \\
(0.013)\end{array}$ & $\begin{array}{l}-0.001 \\
(0.013)\end{array}$ \\
\hline$A V G E D U$ & $\begin{array}{l}0.081 \\
(0.047)\end{array}$ & $\begin{array}{l}0.072 \\
(0.048)\end{array}$ & $\begin{array}{l}0.076 \\
(0.048)\end{array}$ & $\begin{array}{l}0.067 \\
(0.048)\end{array}$ & $\begin{array}{l}0.076 \\
(0.049)\end{array}$ \\
\hline UNION & $\begin{array}{l}0.009 \\
(0.152)\end{array}$ & $\begin{array}{l}0.029 \\
(0.152)\end{array}$ & $\begin{array}{l}0.013 \\
(0.152)\end{array}$ & $\begin{array}{l}0.032 \\
(0.153)\end{array}$ & $\begin{array}{l}0.031 \\
(0.153)\end{array}$ \\
\hline INDEPEND & $\begin{array}{c}-0.958^{* *} \\
(0.170)\end{array}$ & $\begin{array}{c}-0.950^{* *} \\
(0.171)\end{array}$ & $\begin{array}{c}-0.949^{* *} \\
(0.171)\end{array}$ & $\begin{array}{c}-0.941^{* *} \\
(0.171)\end{array}$ & $\begin{array}{c}-0.933^{* *} \\
(0.171)\end{array}$ \\
\hline FOREING & $\begin{array}{c}-0.493^{* *} \\
(0.194)\end{array}$ & $\begin{array}{c}-0.503^{* *} \\
(0.194)\end{array}$ & $\begin{array}{c}-0.491^{* *} \\
(0.194)\end{array}$ & $\begin{array}{c}-0.501^{* *} \\
(0.194)\end{array}$ & $\begin{array}{c}-0.509^{* *} \\
(0.194)\end{array}$ \\
\hline PUBLIC & $\begin{array}{c}-1.731^{* *} \\
(0.248)\end{array}$ & $\begin{array}{c}-1.739^{* *} \\
(0.248)\end{array}$ & $\begin{array}{c}-1.730^{* *} \\
(0.248)\end{array}$ & $\begin{array}{c}-1.739^{* *} \\
(0.248)\end{array}$ & $\begin{array}{c}-1.747^{* *} \\
(0.248)\end{array}$ \\
\hline LONGEV & $\begin{array}{l}-0.001 \\
(0.002)\end{array}$ & $\begin{array}{l}-0.001 \\
(0.002)\end{array}$ & $\begin{array}{l}-0.001 \\
(0.002)\end{array}$ & $\begin{array}{l}-0.001 \\
(0.002)\end{array}$ & $\begin{array}{l}-0.001 \\
(0.002)\end{array}$ \\
\hline $\begin{array}{l}\text { 1-digit Industry } \\
\text { Dummies }\end{array}$ & Yes & Yes & Yes & Yes & Yes \\
\hline $\begin{array}{c}\text { Percentages of } \\
\text { Workforce in each } \\
\text { Occupation }\end{array}$ & Yes & Yes & Yes & Yes & Yes \\
\hline $\begin{array}{c}\text { Number of } \\
\text { observations } \\
\text { L-R test } \chi^{2}\end{array}$ & $\begin{array}{c}1603 \\
597.70^{* *} \\
\end{array}$ & $\begin{array}{c}1603 \\
599.80^{* *} \\
\end{array}$ & $\begin{array}{r}1603 \\
598.57^{* *} \\
\end{array}$ & $\begin{array}{c}1603 \\
600.70^{* *} \\
\end{array}$ & $\begin{array}{c}1603 \\
602.85^{* *} \\
\end{array}$ \\
\hline
\end{tabular}

Significant at the $10 \%$ level. ${ }^{* *}$ Significant at the $5 \%$ level 
Panel 6.2: Whether There Exist Employee Share Ownership Plans

\begin{tabular}{|c|c|c|c|c|c|}
\hline $\begin{array}{l}\text { Dep. Var.: } \\
\text { SHAROWN }\end{array}$ & $\underline{\underline{\text { Model II }}}$ & $\underline{\underline{\text { Model II }}}$ & $\underline{\underline{\text { Model III }}}$ & $\underline{\underline{\text { Model IV }}}$ & $\underline{\underline{\text { Model V }}}$ \\
\hline PROPFEMG & $\begin{array}{l}0.527 \\
(0.337)\end{array}$ & $\begin{array}{l}0.487 \\
(0.382)\end{array}$ & $\begin{array}{l}0.510 \\
(0.354)\end{array}$ & $\begin{array}{l}0.471 \\
(0.397)\end{array}$ & $\begin{array}{l}0.834 \\
(0.908)\end{array}$ \\
\hline PROPWOM & & $\begin{array}{l}0.104 \\
(0.472)\end{array}$ & & $\begin{array}{l}0.103 \\
(0.472)\end{array}$ & $\begin{array}{l}0.216 \\
(0.535)\end{array}$ \\
\hline$F E M G \times W O M$ & & & & & $\begin{array}{c}-0.578 \\
(1.295)\end{array}$ \\
\hline RESPFEMG & & & $\begin{array}{l}0.027 \\
(0.169)\end{array}$ & $\begin{array}{l}0.026 \\
(0.169)\end{array}$ & $\begin{array}{l}0.025 \\
(0.169)\end{array}$ \\
\hline$N U M E M P S \times 10^{-3}$ & $\begin{array}{l}0.113 \\
(0.111)\end{array}$ & $\begin{array}{l}0.114 \\
(0.111)\end{array}$ & $\begin{array}{l}0.114 \\
(0.111)\end{array}$ & $\begin{array}{l}0.114 \\
(0.111)\end{array}$ & $\begin{array}{l}0.111 \\
(0.111)\end{array}$ \\
\hline$A V G A G E$ & $\begin{array}{l}0.013 \\
(0.016)\end{array}$ & $\begin{array}{l}0.014 \\
(0.016)\end{array}$ & $\begin{array}{l}0.013 \\
(0.016)\end{array}$ & $\begin{array}{l}0.013 \\
(0.016)\end{array}$ & $\begin{array}{l}0.014 \\
(0.016)\end{array}$ \\
\hline$A V G E D U$ & $\begin{array}{l}0.141^{* *} \\
(0.060)\end{array}$ & $\begin{array}{c}0.144^{* *} \\
(0.061)\end{array}$ & $\begin{array}{c}0.140^{* *} \\
(0.060)\end{array}$ & $\begin{array}{c}0.143^{* *} \\
(0.062)\end{array}$ & $\begin{array}{c}0.140^{* *} \\
(0.062)\end{array}$ \\
\hline UNION & $\begin{array}{l}0.750^{* *} \\
(0.177)\end{array}$ & $\begin{array}{c}0.745^{* *} \\
(0.179)\end{array}$ & $\begin{array}{c}0.751^{* *} \\
(0.177)\end{array}$ & $\begin{array}{c}0.746^{* *} \\
(0.179)\end{array}$ & $\begin{array}{c}0.745^{* *} \\
(0.179)\end{array}$ \\
\hline INDEPEND & $\begin{array}{c}-2.481^{* *} \\
(0.325)\end{array}$ & $\begin{array}{c}-2.484^{* *} \\
(0.325)\end{array}$ & $\begin{array}{c}-2.479^{* *} \\
(0.325)\end{array}$ & $\begin{array}{c}-2.482^{* *} \\
(0.325)\end{array}$ & $\begin{array}{c}-2.486^{* *} \\
(0.325)\end{array}$ \\
\hline FOREING & $\begin{array}{c}-1.069^{* *} \\
(0.217)\end{array}$ & $\begin{array}{c}-1.068^{* *} \\
(0.217)\end{array}$ & $\begin{array}{c}-1.068^{* *} \\
(0.217)\end{array}$ & $\begin{array}{c}-1.067^{* *} \\
(0.217)\end{array}$ & $\begin{array}{c}-1.066^{* *} \\
(0.217)\end{array}$ \\
\hline PUBLIC & $\begin{array}{c}-35.035 \\
\left(3.35 \times 10^{6}\right)\end{array}$ & $\begin{array}{c}-37.036 \\
\left(9.10 \times 10^{6}\right)\end{array}$ & $\begin{array}{c}-36.035 \\
\left(5.52 \times 10^{6}\right)\end{array}$ & $\begin{array}{c}-37.036 \\
\left(9.10 \times 10^{6}\right)\end{array}$ & $\begin{array}{c}-36.031 \\
\left(5.52 \times 10^{6}\right)\end{array}$ \\
\hline LONGEV & $\begin{array}{l}0.001 \\
(0.002)\end{array}$ & $\begin{array}{l}0.001 \\
(0.002)\end{array}$ & $\begin{array}{l}0.001 \\
(0.002)\end{array}$ & $\begin{array}{l}0.001 \\
(0.002)\end{array}$ & $\begin{array}{l}0.001 \\
(0.002)\end{array}$ \\
\hline $\begin{array}{l}\text { 1-digit Industry } \\
\text { Dummies }\end{array}$ & Yes & Yes & Yes & Yes & Yes \\
\hline $\begin{array}{c}\text { Percentages of } \\
\text { Workforce in each } \\
\text { Occupation }\end{array}$ & Yes & Yes & Yes & Yes & Yes \\
\hline $\begin{array}{c}\text { Number of } \\
\text { observations }\end{array}$ & 1603 & 1603 & 1603 & 1603 & 1603 \\
\hline$L-R$ test $\chi^{2}$ & $692.57^{* *}$ & $692.62^{* *}$ & $692.60^{* *}$ & $692.64^{* *}$ & $692.85^{* *}$ \\
\hline
\end{tabular}

*Significant at the $10 \%$ level. ${ }^{* * *}$ Significant at the $5 \%$ level 
Panel 6.3: Whether There Exist Pay per Performance Schemes

\begin{tabular}{|c|c|c|c|c|c|}
\hline $\begin{array}{l}\text { Dep. Var.: } \\
\text { PAYPERF }\end{array}$ & $\underline{\underline{\text { Model I }}}$ & $\underline{\underline{\text { Model II }}}$ & $\underline{\underline{\text { Model III }}}$ & $\underline{\underline{\text { Model IV }}}$ & Model V \\
\hline PROPFEMG & $\begin{array}{l}-0.219 \\
(0.267)\end{array}$ & $\begin{array}{l}0.161 \\
(0.304)\end{array}$ & $\begin{array}{l}-0.135 \\
(0.282)\end{array}$ & $\begin{array}{l}0.243 \\
(0.317)\end{array}$ & $\begin{array}{l}0.974 \\
(0.705)\end{array}$ \\
\hline PROPWOM & & $\begin{array}{c}-1.099^{* *} \\
(0.403)\end{array}$ & & $\begin{array}{c}-1.097^{* *} \\
(0.401)\end{array}$ & $\begin{array}{c}-0.843^{*} \\
(0.455)\end{array}$ \\
\hline$F E M G \times W O M$ & & & & & $\begin{array}{c}-1.158 \\
(1.003)\end{array}$ \\
\hline RESPFEMG & & & $\begin{array}{l}-0.127 \\
(0.139)\end{array}$ & $\begin{array}{l}-0.127 \\
(0.139)\end{array}$ & $\begin{array}{c}-0.126 \\
(0.138)\end{array}$ \\
\hline$N U M E M P S \times 10^{-3}$ & $\begin{array}{c}0.407^{\text {** }} \\
(0.114)\end{array}$ & $\begin{array}{c}0.411^{* *} \\
(0.115)\end{array}$ & $\begin{array}{c}0.406^{* *} \\
(0.114)\end{array}$ & $\begin{array}{c}0.410^{* *} \\
(0.115)\end{array}$ & $\begin{array}{c}0.396^{* *} \\
(0.115)\end{array}$ \\
\hline$A V G A G E$ & $\begin{array}{l}0.016 \\
(0.014)\end{array}$ & $\begin{array}{c}-0.020 \\
(0.014)\end{array}$ & $\begin{array}{c}-0.016 \\
(0.014)\end{array}$ & $\begin{array}{l}-0.020 \\
(0.014)\end{array}$ & $\begin{array}{c}-0.019 \\
(0.014)\end{array}$ \\
\hline$A V G E D U$ & $\begin{array}{l}0.075 \\
(0.046)\end{array}$ & $\begin{array}{l}0.058 \\
(0.047)\end{array}$ & $\begin{array}{l}0.079^{*} \\
(0.046)\end{array}$ & $\begin{array}{l}0.062 \\
(0.047)\end{array}$ & $\begin{array}{l}0.056 \\
(0.047)\end{array}$ \\
\hline UNION & $\begin{array}{l}0.021 \\
(0.166)\end{array}$ & $\begin{array}{l}0.069 \\
(0.168)\end{array}$ & $\begin{array}{l}0.014 \\
(0.166)\end{array}$ & $\begin{array}{l}0.063 \\
(0.168)\end{array}$ & $\begin{array}{l}0.066 \\
(0.168)\end{array}$ \\
\hline INDEPEND & $\begin{array}{r}-0.142 \\
(0.183)\end{array}$ & $\begin{array}{c}-0.120 \\
(0.183)\end{array}$ & $\begin{array}{l}-0.150 \\
(0.183)\end{array}$ & $\begin{array}{l}-0.128 \\
(0.184)\end{array}$ & $\begin{array}{c}-0.135 \\
(0.184)\end{array}$ \\
\hline FOREING & $\begin{array}{l}0.204 \\
(0.204)\end{array}$ & $\begin{array}{l}0.186 \\
(0.204)\end{array}$ & $\begin{array}{l}0.201 \\
(0.204)\end{array}$ & $\begin{array}{l}0.183 \\
(0.205)\end{array}$ & $\begin{array}{l}0.185 \\
(0.205)\end{array}$ \\
\hline PUBLIC & $\begin{array}{c}0.787^{* *} \\
(0.234)\end{array}$ & $\begin{array}{c}0.777^{* *} \\
(0.233)\end{array}$ & $\begin{array}{c}0.792^{* *} \\
(0.234)\end{array}$ & $\begin{array}{l}0.781^{*} \\
(0.234)\end{array}$ & $\begin{array}{c}0.789^{* *} \\
(0.234)\end{array}$ \\
\hline LONGEV & $\begin{array}{l}0.002 \\
(0.002)\end{array}$ & $\begin{array}{l}0.002 \\
(0.002)\end{array}$ & $\begin{array}{l}0.002 \\
(0.002)\end{array}$ & $\begin{array}{l}0.002 \\
(0.002)\end{array}$ & $\begin{array}{l}0.002 \\
(0.002)\end{array}$ \\
\hline $\begin{array}{c}\text { 1-digit Industry } \\
\text { Dummies }\end{array}$ & Yes & Yes & Yes & Yes & Yes \\
\hline $\begin{array}{c}\text { Percentages of } \\
\text { Workforce in each } \\
\text { Occupation }\end{array}$ & Yes & Yes & Yes & Yes & Yes \\
\hline $\begin{array}{c}\text { Number of } \\
\text { observations }\end{array}$ & 1603 & 1603 & 1603 & 1603 & 1603 \\
\hline$L-R$ test $\chi^{2}$ & $206.81^{* *}$ & $214.48^{* *}$ & $207.66^{* *}$ & $215.32^{* *}$ & $216.67^{* *}$ \\
\hline
\end{tabular}

* Significant at the $10 \%$ level. ${ }^{* *}$ Significant at the 5\% level. 
Table 7: Effect of the proportion of women at the management on the degree of delegation of managerial tasks on subordinates. Logit estimates with standard errors in parentheses.

Panel 7.1: Proportion of Non-Managerial Workers doing Supervisory Tasks

\begin{tabular}{|c|c|c|c|c|c|}
\hline $\begin{array}{l}\text { Dep. Var.: } \\
\text { EMPSUPV }\end{array}$ & $\underline{\underline{\text { Model I }}}$ & $\underline{\text { Model II }}$ & $\underline{\underline{\text { Model III }}}$ & $\underline{\underline{\text { Model IV }}}$ & Model V \\
\hline PROPFEMG & $\begin{array}{l}-0.125 \\
(0.193)\end{array}$ & $\begin{array}{l}-0.098 \\
(0.214)\end{array}$ & $\begin{array}{r}-0.154 \\
(0.207)\end{array}$ & $\begin{array}{l}-0.126 \\
(0.227)\end{array}$ & $\begin{array}{l}0.591 \\
(0.544)\end{array}$ \\
\hline PROPWOM & & $\begin{array}{r}-0.089 \\
(0.296)\end{array}$ & & $\begin{array}{l}-0.087 \\
(0.296)\end{array}$ & $\begin{array}{l}0.136 \\
(0.333)\end{array}$ \\
\hline$F E M G \times W O M$ & & & & & $\begin{array}{c}-1.037 \\
(0.715)\end{array}$ \\
\hline RESPFEMG & & & $\begin{array}{l}0.040 \\
(0.107)\end{array}$ & $\begin{array}{l}0.040 \\
(0.107)\end{array}$ & $\begin{array}{l}0.045 \\
(0.107)\end{array}$ \\
\hline$N U M E M P S \times 10^{-3}$ & $\begin{array}{l}0.304^{* *} \\
(0.077)\end{array}$ & $\begin{array}{l}0.304^{* *} \\
(0.077)\end{array}$ & $\begin{array}{l}0.304^{* *} \\
(0.077)\end{array}$ & $\begin{array}{l}0.304^{* *} \\
(0.077)\end{array}$ & $\begin{array}{l}0.290^{* *} \\
(0.076)\end{array}$ \\
\hline$A V G A G E$ & $\begin{array}{l}-0.007 \\
(0.010)\end{array}$ & $\begin{array}{l}-0.008 \\
(0.010)\end{array}$ & $\begin{array}{l}-0.008 \\
(0.010)\end{array}$ & $\begin{array}{l}-0.007 \\
(0.010)\end{array}$ & $\begin{array}{c}-0.007 \\
(0.010)\end{array}$ \\
\hline$A V G E D U$ & $\begin{array}{c}0.115^{* *} \\
(0.036)\end{array}$ & $\begin{array}{l}0.113^{* *} \\
(0.036)\end{array}$ & $\begin{array}{c}0.114^{* *} \\
(0.036)\end{array}$ & $\begin{array}{c}0.113^{* *} \\
(0.036)\end{array}$ & $\begin{array}{c}0.107^{* *} \\
(0.036)\end{array}$ \\
\hline UNION & $\begin{array}{l}0.106 \\
(0.126)\end{array}$ & $\begin{array}{l}0.109 \\
(0.127)\end{array}$ & $\begin{array}{l}0.107 \\
(0.126)\end{array}$ & $\begin{array}{l}0.109 \\
(0.127)\end{array}$ & $\begin{array}{l}0.111 \\
(0.127)\end{array}$ \\
\hline INDEPEND & $\begin{array}{l}-0.024 \\
(0.129)\end{array}$ & $\begin{array}{l}-0.024 \\
(0.129)\end{array}$ & $\begin{array}{l}-0.022 \\
(0.129)\end{array}$ & $\begin{array}{l}-0.022 \\
(0.129)\end{array}$ & $\begin{array}{l}-0.029 \\
(0.129)\end{array}$ \\
\hline FOREING & $\begin{array}{l}0.372^{* *} \\
(0.165)\end{array}$ & $\begin{array}{l}0.371^{* *} \\
(0.165)\end{array}$ & $\begin{array}{c}0.374^{* *} \\
(0.165)\end{array}$ & $\begin{array}{c}0.372^{* *} \\
(0.165)\end{array}$ & $\begin{array}{c}0.380^{* *} \\
(0.165)\end{array}$ \\
\hline PUBLIC & $\begin{array}{l}-0.008 \\
(0.165)\end{array}$ & $\begin{array}{r}-0.009 \\
(0.168)\end{array}$ & $\begin{array}{l}-0.007 \\
(0.168)\end{array}$ & $\begin{array}{l}-0.008 \\
(0.168)\end{array}$ & $\begin{array}{l}-0.009 \\
(0.168)\end{array}$ \\
\hline$L O N G E V$ & $\begin{array}{l}0.001 \\
(0.001)\end{array}$ & $\begin{array}{l}0.001 \\
(0.001)\end{array}$ & $\begin{array}{l}0.001 \\
(0.001)\end{array}$ & $\begin{array}{l}0.001 \\
(0.001)\end{array}$ & $\begin{array}{l}0.001 \\
(0.001)\end{array}$ \\
\hline $\begin{array}{c}\text { 1-digit Industry } \\
\text { Dummies }\end{array}$ & Yes & Yes & Yes & Yes & Yes \\
\hline $\begin{array}{c}\text { Percentages of } \\
\text { Workforce in each } \\
\text { Occupation }\end{array}$ & Yes & Yes & Yes & Yes & Yes \\
\hline $\begin{array}{c}\text { Number of } \\
\text { observations }\end{array}$ & 1597 & 1597 & 1597 & 1597 & 1597 \\
\hline$L-R$ test $\chi^{2}$ & $115.92^{* *}$ & $116.01^{* *}$ & $116.06^{* *}$ & $116.15^{* *}$ & $118.26^{* *}$ \\
\hline
\end{tabular}

Significant at the $10 \%$ level. ${ }^{* *}$ Significant at the $5 \%$ level 
Panel 7.2: Whether Supervisors Have the Authority to Make Hiring Decisions

\begin{tabular}{|c|c|c|c|c|c|}
\hline $\begin{array}{l}\text { Dep. Var.: } \\
\text { SUPVTAKE }\end{array}$ & Model I & $\underline{\underline{\text { Model II }}}$ & $\underline{\underline{\text { Model III }}}$ & $\underline{\underline{\text { Model IV }}}$ & Model V \\
\hline PROPFEMG & $\begin{array}{l}-0.168 \\
(0.244)\end{array}$ & $\begin{array}{r}-0.147 \\
(0.274)\end{array}$ & $\begin{array}{l}-0.141 \\
(0.258)\end{array}$ & $\begin{array}{l}-0.120 \\
(0.286)\end{array}$ & $\begin{array}{l}1.029 \\
(0.650)\end{array}$ \\
\hline PROPWOM & & $\begin{array}{c}-0.060 \\
(0.359)\end{array}$ & & $\begin{array}{l}-0.061 \\
(0.359)\end{array}$ & $\begin{array}{l}0.313 \\
(0.404)\end{array}$ \\
\hline$F E M G \times W O M$ & & & & & $\begin{array}{c}-1.727^{*} \\
(0.883)\end{array}$ \\
\hline RESPFEMG & & & $\begin{array}{l}-0.043 \\
(0.130)\end{array}$ & $\begin{array}{l}-0.043 \\
(0.130)\end{array}$ & $\begin{array}{c}-0.037 \\
(0.130)\end{array}$ \\
\hline$N U M E M P S \times 10^{-3}$ & $\begin{array}{c}0.328^{* *} \\
(0.110)\end{array}$ & $\begin{array}{c}0.328^{* *} \\
(0.110)\end{array}$ & $\begin{array}{c}0.328^{* *} \\
(0.110)\end{array}$ & $\begin{array}{c}0.328^{* *} \\
(0.110)\end{array}$ & $\begin{array}{c}0.303^{* *} \\
(0.111)\end{array}$ \\
\hline$A V G A G E$ & $\begin{array}{l}0.006 \\
(0.012)\end{array}$ & $\begin{array}{l}0.006 \\
(0.011)\end{array}$ & $\begin{array}{l}0.006 \\
(0.012)\end{array}$ & $\begin{array}{l}0.006 \\
(0.012)\end{array}$ & $\begin{array}{l}0.007 \\
(0.012)\end{array}$ \\
\hline$A V G E D U$ & $\begin{array}{l}0.040 \\
(0.043)\end{array}$ & $\begin{array}{l}0.039 \\
(0.044)\end{array}$ & $\begin{array}{l}0.041 \\
(0.044)\end{array}$ & $\begin{array}{l}0.040 \\
(0.044)\end{array}$ & $\begin{array}{l}0.031 \\
(0.044)\end{array}$ \\
\hline UNION & $\begin{array}{l}0.242 \\
(0.151)\end{array}$ & $\begin{array}{l}0.244 \\
(0.151)\end{array}$ & $\begin{array}{l}0.241 \\
(0.151)\end{array}$ & $\begin{array}{l}0.243 \\
(0.151)\end{array}$ & $\begin{array}{l}0.248 \\
(0.151)\end{array}$ \\
\hline INDEPEND & $\begin{array}{l}-0.014 \\
(0.159)\end{array}$ & $\begin{array}{c}-0.014 \\
(0.159)\end{array}$ & $\begin{array}{l}-0.016 \\
(0.159)\end{array}$ & $\begin{array}{l}-0.015 \\
(0.159)\end{array}$ & $\begin{array}{c}-0.028 \\
(0.159)\end{array}$ \\
\hline FOREING & $\begin{array}{l}0.198 \\
(0.193)\end{array}$ & $\begin{array}{l}0.197 \\
(0.193)\end{array}$ & $\begin{array}{l}0.197 \\
(0.193)\end{array}$ & $\begin{array}{l}0.196 \\
(0.193)\end{array}$ & $\begin{array}{l}0.205 \\
(0.194)\end{array}$ \\
\hline PUBLIC & $\begin{array}{l}-0.215 \\
(0.207)\end{array}$ & $\begin{array}{c}-0.216 \\
(0.207)\end{array}$ & $\begin{array}{l}-0.216 \\
(0.207)\end{array}$ & $\begin{array}{l}-0.238 \\
(0.207)\end{array}$ & $\begin{array}{r}-0.217 \\
(0.208)\end{array}$ \\
\hline LONGEV & $\begin{array}{r}-0.002 \\
(0.002)\end{array}$ & $\begin{array}{r}-0.002 \\
(0.002)\end{array}$ & $\begin{array}{l}-0.002 \\
(0.002)\end{array}$ & $\begin{array}{l}-0.002 \\
(0.002)\end{array}$ & $\begin{array}{l}-0.002 \\
(0.002)\end{array}$ \\
\hline $\begin{array}{c}\text { 1-digit Industry } \\
\text { Dummies }\end{array}$ & Yes & Yes & Yes & Yes & Yes \\
\hline $\begin{array}{c}\text { Percentages of } \\
\text { Workforce in each } \\
\text { Occupation }\end{array}$ & Yes & Yes & Yes & Yes & Yes \\
\hline $\begin{array}{c}\text { Number of } \\
\text { observations }\end{array}$ & 1597 & 1597 & 1597 & 1597 & 1597 \\
\hline$L-R$ test $\chi^{2}$ & $101.82^{* *}$ & $101.85^{* *}$ & $101.93^{* *}$ & $101.96^{* *}$ & $105.82^{* *}$ \\
\hline
\end{tabular}

\footnotetext{
Significant at the $10 \%$ level. ${ }^{* * *}$ Significant at the $5 \%$ level
} 
Panel 7.3: Whether Supervisors Have the Authority to Decide on Pay Rising

\begin{tabular}{|c|c|c|c|c|c|}
\hline $\begin{array}{l}\text { Dep. Var.: } \\
\text { SUPVPAY }\end{array}$ & $\underline{\underline{\text { Model I }}}$ & Model II & $\underline{\underline{\text { Model III }}}$ & $\underline{\underline{\text { Model IV }}}$ & Model V \\
\hline PROPFEMG & $\begin{array}{l}-0.056 \\
(0.577)\end{array}$ & $\begin{array}{l}0.237 \\
(0.658)\end{array}$ & $\begin{array}{l}-0.063 \\
(0.604)\end{array}$ & $\begin{array}{l}0.229 \\
(0.680)\end{array}$ & $\begin{array}{l}1.103 \\
(1.472)\end{array}$ \\
\hline PROPWOM & & $\begin{array}{c}-0.854 \\
(0.888)\end{array}$ & & $\begin{array}{l}-0.855 \\
(0.888)\end{array}$ & $\begin{array}{l}-0.505 \\
(1.027)\end{array}$ \\
\hline$F E M G \times W O M$ & & & & & $\begin{array}{c}-1.422^{*} \\
(2.175)\end{array}$ \\
\hline RESPFEMG & & & $\begin{array}{l}0.011 \\
(0.301)\end{array}$ & $\begin{array}{l}0.014 \\
(0.301)\end{array}$ & $\begin{array}{l}0.019 \\
(0.299)\end{array}$ \\
\hline$N U M E M P S \times 10^{-3}$ & $\begin{array}{l}-0.063 \\
(0.278)\end{array}$ & $\begin{array}{l}-0.068 \\
(0.279)\end{array}$ & $\begin{array}{l}-0.063 \\
(0.278)\end{array}$ & $\begin{array}{l}-0.068 \\
(0.279)\end{array}$ & $\begin{array}{l}-0.081 \\
(0.285)\end{array}$ \\
\hline$A V G A G E$ & $\begin{array}{l}0.024 \\
(0.028)\end{array}$ & $\begin{array}{l}0.021 \\
(0.028)\end{array}$ & $\begin{array}{l}0.024 \\
(0.028)\end{array}$ & $\begin{array}{l}0.021 \\
(0.028)\end{array}$ & $\begin{array}{l}0.022 \\
(0.028)\end{array}$ \\
\hline$A V G E D U$ & $\begin{array}{l}0.001 \\
(0.097)\end{array}$ & $\begin{array}{l}-0.013 \\
(0.098)\end{array}$ & $\begin{array}{l}0.000 \\
(0.098)\end{array}$ & $\begin{array}{l}-0.014 \\
(0.099)\end{array}$ & $\begin{array}{c}-0.021 \\
(0.100)\end{array}$ \\
\hline UNION & $\begin{array}{l}-0.278 \\
(0.353)\end{array}$ & $\begin{array}{l}-0.258 \\
(0.355)\end{array}$ & $\begin{array}{r}-0.277 \\
(0.353)\end{array}$ & $\begin{array}{l}-0.258 \\
(0.355)\end{array}$ & $\begin{array}{c}-0.248 \\
(0.355)\end{array}$ \\
\hline INDEPEND & $\begin{array}{l}0.545 \\
(0.359)\end{array}$ & $\begin{array}{l}0.566 \\
(0.359)\end{array}$ & $\begin{array}{l}0.545 \\
(0.359)\end{array}$ & $\begin{array}{l}0.566 \\
(0.359)\end{array}$ & $\begin{array}{l}0.555 \\
(0.359)\end{array}$ \\
\hline FOREING & $\begin{array}{l}0.579 \\
(0.380)\end{array}$ & $\begin{array}{l}0.565 \\
(0.381)\end{array}$ & $\begin{array}{l}0.579 \\
(0.381)\end{array}$ & $\begin{array}{l}0.565 \\
(0.381)\end{array}$ & $\begin{array}{l}0.569 \\
(0.381)\end{array}$ \\
\hline PUBLIC & $\begin{array}{l}-0.324 \\
(0.618)\end{array}$ & $\begin{array}{l}-0.309 \\
(0.618)\end{array}$ & $\begin{array}{l}-0.324 \\
(0.618)\end{array}$ & $\begin{array}{l}-0.308 \\
(0.618)\end{array}$ & $\begin{array}{l}-0.309 \\
(0.620)\end{array}$ \\
\hline LONGEV & $\begin{array}{l}-0.004 \\
(0.004)\end{array}$ & $\begin{array}{l}-0.003 \\
(0.004)\end{array}$ & $\begin{array}{l}-0.004 \\
(0.004)\end{array}$ & $\begin{array}{l}-0.004 \\
(0.004)\end{array}$ & $\begin{array}{c}-0.004 \\
(0.004)\end{array}$ \\
\hline $\begin{array}{c}\text { 1-digit Industry } \\
\text { Dummies }\end{array}$ & Yes & Yes & Yes & Yes & Yes \\
\hline $\begin{array}{c}\text { Percentages of } \\
\text { Workforce in each } \\
\text { Occupation }\end{array}$ & Yes & Yes & Yes & Yes & Yes \\
\hline $\begin{array}{c}\text { Number of } \\
\text { observations }\end{array}$ & 1597 & 1597 & 1597 & 1597 & 1597 \\
\hline$L-R$ test $\chi^{2}$ & 33.87 & 34.82 & 33.87 & 34.82 & 35.24 \\
\hline
\end{tabular}

\footnotetext{
Significant at the $10 \%$ level. ${ }^{* *}$ Significant at the $5 \%$ level.
} 
Panel 7.4: Whether Supervisors Have Authority on Dismissals

\begin{tabular}{|c|c|c|c|c|c|}
\hline $\begin{array}{l}\text { Dep. Var.: } \\
\text { SUPVDISM }\end{array}$ & Model I & Model II & $\underline{\underline{\text { Model III }}}$ & $\underline{\underline{\text { Model IV }}}$ & $\underline{\underline{\text { Model V }}}$ \\
\hline PROPFEMG & $\begin{array}{c}-0.320 \\
(0.465)\end{array}$ & $\begin{array}{c}-0.337 \\
(0.533)\end{array}$ & $\begin{array}{c}-0.388 \\
(0.489)\end{array}$ & $\begin{array}{l}-0.260 \\
(0.552)\end{array}$ & $\begin{array}{l}0.697 \\
(1.014)\end{array}$ \\
\hline PROPWOM & & $\begin{array}{c}-1.788^{* *} \\
(0.666)\end{array}$ & & $\begin{array}{c}-1.804^{* *} \\
(0.669)\end{array}$ & $\begin{array}{c}-1.552^{* *} \\
(0.776)\end{array}$ \\
\hline$F E M G \times W O M$ & & & & & $\begin{array}{l}-0.797 \\
(2.174)\end{array}$ \\
\hline RESPFEMG & & & $\begin{array}{l}0.111 \\
(0.237)\end{array}$ & $\begin{array}{l}0.130 \\
(0.238)\end{array}$ & $\begin{array}{l}0.130 \\
(0.237)\end{array}$ \\
\hline$N U M E M P S \times 10^{-3}$ & $\begin{array}{c}-0.347^{* *} \\
(0.143)\end{array}$ & $\begin{array}{c}-0.352^{* *} \\
(0.145)\end{array}$ & $\begin{array}{c}-0.349^{* *} \\
(0.144)\end{array}$ & $\begin{array}{c}-0.354^{* *} \\
(0.145)\end{array}$ & $\begin{array}{c}-0.346^{* *} \\
(0.145)\end{array}$ \\
\hline$A V G A G E$ & $\begin{array}{l}0.003 \\
(0.020)\end{array}$ & $\begin{array}{l}0.001 \\
(0.020)\end{array}$ & $\begin{array}{l}0.002 \\
(0.020)\end{array}$ & $\begin{array}{l}0.000 \\
(0.020)\end{array}$ & $\begin{array}{l}0.000 \\
(0.020)\end{array}$ \\
\hline$A V G E D U$ & $\begin{array}{l}0.042 \\
(0.077)\end{array}$ & $\begin{array}{l}0.016 \\
(0.077)\end{array}$ & $\begin{array}{l}0.037 \\
(0.077)\end{array}$ & $\begin{array}{l}0.011 \\
(0.078)\end{array}$ & $\begin{array}{c}-0.000 \\
(0.078)\end{array}$ \\
\hline UNION & $\begin{array}{l}-0.207 \\
(0.258)\end{array}$ & $\begin{array}{c}-0.178 \\
(0.262)\end{array}$ & $\begin{array}{l}-0.204 \\
(0.258)\end{array}$ & $\begin{array}{l}0.171 \\
(0.262)\end{array}$ & $\begin{array}{l}-0.175 \\
(0.262)\end{array}$ \\
\hline INDEPEND & $\begin{array}{c}0.882^{* *} \\
(0.256)\end{array}$ & $\begin{array}{c}0.943^{* *} \\
(0.258)\end{array}$ & $\begin{array}{c}0.892^{* *} \\
(0.257)\end{array}$ & $\begin{array}{c}0.962^{* *} \\
(0.259)\end{array}$ & $\begin{array}{c}0.954^{* *} \\
(0.259)\end{array}$ \\
\hline FOREING & $\begin{array}{l}0.534^{*} \\
(0.305)\end{array}$ & $\begin{array}{l}0.539^{*} \\
(0.304)\end{array}$ & $\begin{array}{c}0.538^{*} \\
(0.305)\end{array}$ & $\begin{array}{l}0.549^{*} \\
(0.305)\end{array}$ & $\begin{array}{l}0.544^{*} \\
(0.305)\end{array}$ \\
\hline PUBLIC & $\begin{array}{c}-0.826^{*} \\
(0.465)\end{array}$ & $\begin{array}{c}-0.847^{*} \\
(0.466)\end{array}$ & $\begin{array}{c}-0.825^{*} \\
(0.465)\end{array}$ & $\begin{array}{c}-0.843^{*} \\
(0.466)\end{array}$ & $\begin{array}{c}-0.846^{*} \\
(0.466)\end{array}$ \\
\hline LONGEV & $\begin{array}{l}-0.001 \\
(0.002)\end{array}$ & $\begin{array}{l}0.001 \\
(0.003)\end{array}$ & $\begin{array}{l}-0.001 \\
(0.003)\end{array}$ & $\begin{array}{l}0.001 \\
(0.003)\end{array}$ & $\begin{array}{l}0.001 \\
(0.003)\end{array}$ \\
\hline $\begin{array}{c}\text { 1-digit Industry } \\
\text { Dummies }\end{array}$ & Yes & Yes & Yes & Yes & Yes \\
\hline $\begin{array}{l}\text { Percentages of } \\
\text { Workforce in each } \\
\text { Occupation }\end{array}$ & Yes & Yes & Yes & Yes & Yes \\
\hline $\begin{array}{c}\text { Number of } \\
\text { observations }\end{array}$ & 1597 & 1597 & 1597 & 1597 & 1597 \\
\hline$L-R$ test $\chi^{2}$ & $112.57^{* *}$ & $120.10^{* *}$ & $112.79^{* *}$ & $120.39^{* *}$ & $120.15^{* *}$ \\
\hline
\end{tabular}

* Significant at the $10 \%$ level. ${ }^{* * *}$ Significant at the 5\% level. 
Table 8: Correlation Between the Dependent Variables (Corresponding P-Values Below).

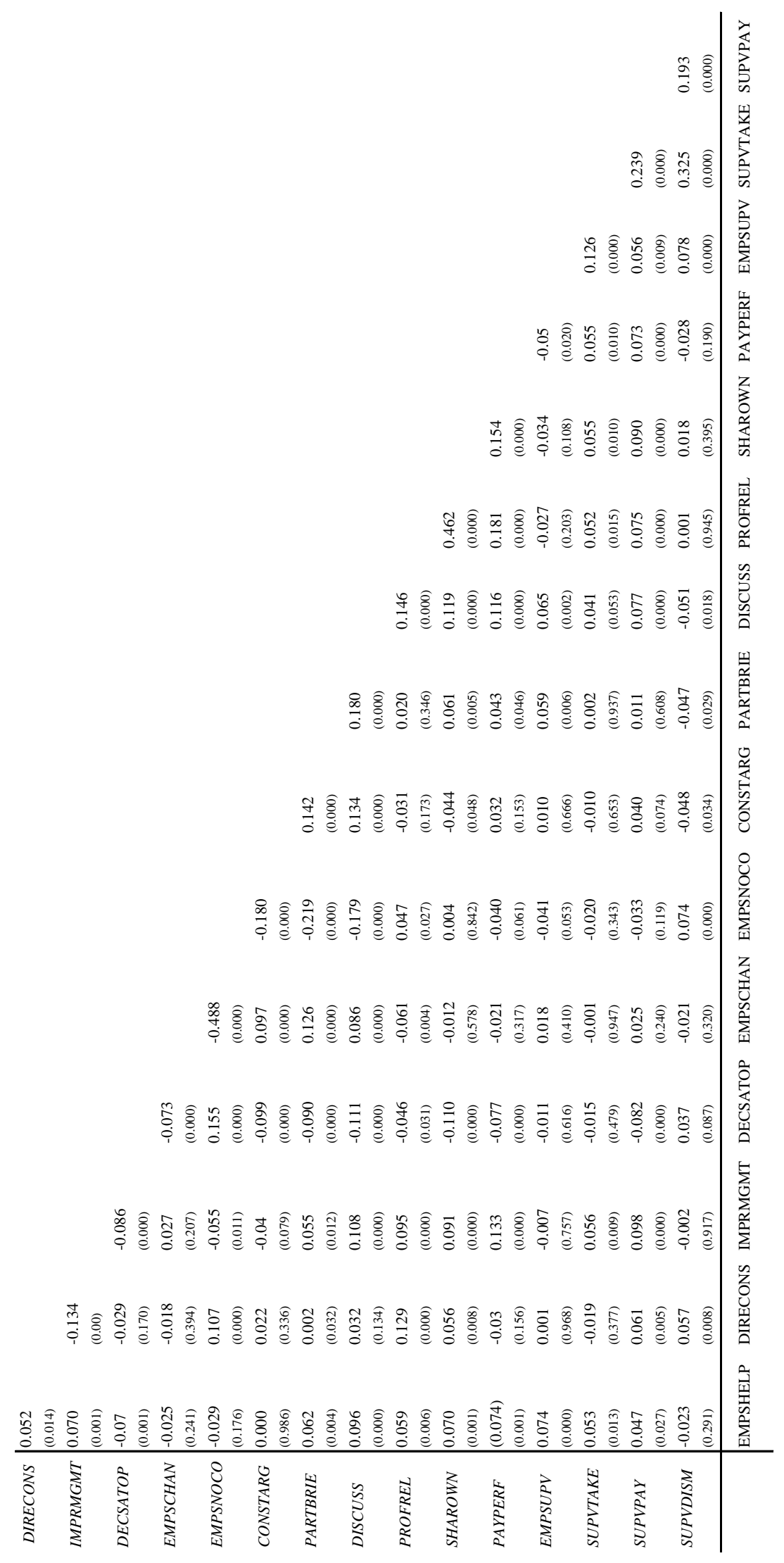


Table 9: Results from Principal Component and Maximum-Likelihood Factor Analysis of the 16 Dependent Variables Related to Hypotheses.

Panel 3.9.1: Principal Components Factor Analysis (5 Components Retained):

\begin{tabular}{|c|c|c|c|c|c|}
\hline Component & Eigenvalue & \multicolumn{2}{|c|}{ Difference } & Proportion & Cumulative \\
\hline 1 & 1.92913 & \multicolumn{2}{|c|}{0.17357} & 0.1206 & 0.1206 \\
\hline 2 & 1.75556 & \multicolumn{2}{|c|}{0.27005} & 0.1097 & 0.2303 \\
\hline 3 & 1.48551 & \multicolumn{2}{|c|}{0.28777} & 0.0928 & 0.3231 \\
\hline 4 & 1.19774 & \multicolumn{2}{|c|}{0.09662} & 0.0749 & 0.398 \\
\hline 5 & 1.10111 & \multicolumn{2}{|c|}{0.10293} & 0.0688 & 0.4668 \\
\hline 6 & 0.99819 & \multicolumn{2}{|c|}{0.0434} & 0.0624 & 0.5292 \\
\hline 7 & \multirow{2}{*}{$\begin{array}{l}0.95478 \\
0.91626\end{array}$} & \multicolumn{2}{|c|}{0.03852} & 0.0597 & 0.5889 \\
\hline 8 & & \multicolumn{2}{|c|}{0.04842} & 0.0573 & 0.6461 \\
\hline 9 & $\begin{array}{l}0.91626 \\
0.86785\end{array}$ & \multicolumn{2}{|c|}{0.01079} & 0.0542 & 0.7004 \\
\hline 10 & 0.85706 & \multicolumn{2}{|c|}{0.05616} & 0.0536 & 0.7539 \\
\hline 11 & 0.8009 & \multicolumn{2}{|c|}{0.03201} & 0.0501 & 0.804 \\
\hline 12 & 0.76889 & \multicolumn{2}{|c|}{0.05107} & 0.0481 & 0.8521 \\
\hline 13 & 0.71782 & \multicolumn{2}{|c|}{0.06713} & 0.0449 & 0.8969 \\
\hline 14 & 0.65069 & \multirow{2}{*}{\multicolumn{2}{|c|}{0.13036}} & 0.0407 & 0.9376 \\
\hline 15 & 0.52033 & & 216 & 0.0325 & 0.9701 \\
\hline 16 & 0.47817 & & & 0.0299 & 1 \\
\hline Variable & Eigenvector 1 & Eigenvector 2 & Eigenvector 3 & Eigenvector 4 & Eigenvector 5 \\
\hline EMPSHELP & 0.15407 & 0.0847 & -0.02283 & 0.03291 & 0.61518 \\
\hline DIRECONS & 0.04299 & 0.18678 & -0.04388 & 0.65481 & -0.0209 \\
\hline$I M P R M G M T$ & 0.22028 & 0.07112 & -0.0632 & -0.55293 & 0.21153 \\
\hline DECSATOP & -0.28288 & 0.06645 & 0.06443 & 0.08714 & -0.15736 \\
\hline EMPSCHAN & 0.28876 & -0.40633 & 0.10854 & -0.03078 & -0.36568 \\
\hline EMPSNOCO & -0.37659 & 0.43971 & -0.06679 & 0.07223 & 0.21059 \\
\hline CONSTARG & 0.21323 & -0.25485 & -0.00155 & 0.29494 & 0.0701 \\
\hline PARTBRIE & 0.28822 & -0.19706 & -0.04455 & 0.16072 & 0.1582 \\
\hline DISCUSS & 0.35308 & -0.03547 & -0.10421 & 0.21256 & 0.15724 \\
\hline PROFREL & 0.28857 & 0.40013 & -0.31789 & 0.09625 & -0.22401 \\
\hline SHAROWN & 0.31151 & 0.35128 & -0.2864 & -0.00595 & -0.2547 \\
\hline PAYPERF & 0.25088 & 0.1699 & -0.18319 & -0.2393 & 0.0789 \\
\hline EMPSUPV & 0.09105 & -0.01731 & 0.29697 & 0.14321 & 0.39496 \\
\hline SUPVTAKE & 0.20153 & 0.24267 & 0.50039 & -0.07377 & -0.03751 \\
\hline$S U P V P A Y$ & 0.26688 & 0.21424 & 0.36189 & 0.00102 & -0.02878 \\
\hline SUPVDISM & 0.06392 & 0.25985 & 0.52359 & 0.01133 & -0.1984 \\
\hline
\end{tabular}


Panel 9.2: Maximum Likelihood Factor Analysis (10 Components Obtained)

\begin{tabular}{|c|c|c|c|c|c|}
\hline Factor & Variance & \multicolumn{2}{|c|}{ Difference } & Proportion & Cumulative \\
\hline 1 & 1.07221 & \multicolumn{2}{|c|}{-0.04353} & 0.1619 & 0.1619 \\
\hline 2 & 1.11574 & \multicolumn{2}{|c|}{-0.07465} & 0.1685 & 0.3305 \\
\hline 3 & 1.19039 & \multicolumn{2}{|c|}{0.08078} & 0.1798 & 0.5102 \\
\hline 4 & 1.1096 & \multicolumn{2}{|c|}{0.24206} & 0.1676 & 0.6778 \\
\hline 5 & 0.86754 & \multicolumn{2}{|c|}{0.38321} & 0.131 & 0.8089 \\
\hline 6 & 0.48433 & \multicolumn{2}{|c|}{0.20855} & 0.0732 & 0.882 \\
\hline 7 & 0.27578 & \multicolumn{2}{|c|}{0.08552} & 0.0417 & 0.9237 \\
\hline 8 & 0.19026 & \multicolumn{2}{|c|}{0.0195} & 0.0287 & 0.9524 \\
\hline 9 & 0.17075 & \multicolumn{2}{|c|}{0.02639} & 0.0258 & 0.9782 \\
\hline 10 & 0.14436 & \multicolumn{2}{|c|}{. } & 0.0218 & 1 \\
\hline \multirow[t]{2}{*}{ Variable } & Rotated & Rotated & Rotated & Rotated & Rotated \\
\hline & Factor 1 & Factor 2 & Factor 3 & Factor 4 & Factor 5 \\
\hline EMPSHELP & 0.0588 & 0.03931 & 0.0428 & -0.00368 & 0.02196 \\
\hline DIRECONS & 0.99816 & 0.00775 & 0.03208 & 0.04232 & 0.00848 \\
\hline$I M P R M G M T$ & -0.12228 & 0.03947 & 0.08326 & -0.03146 & 0.0335 \\
\hline DECSATOP & 0.00538 & -0.05919 & -0.10777 & 0.15131 & 0.0014 \\
\hline EMPSCHAN & -0.00073 & 0.06622 & -0.02029 & -0.57696 & 0.0105 \\
\hline EMPSNOCO & 0.07347 & -0.1271 & 0.0086 & 0.8375 & 0.00687 \\
\hline CONSTARG & 0.02872 & 0.12667 & -0.05945 & -0.18096 & -0.03129 \\
\hline PARTBRIE & 0.00773 & 0.99571 & 0.02373 & -0.08657 & -0.00376 \\
\hline DISCUSS & 0.07666 & 0.11947 & 0.10532 & -0.15142 & 0.0077 \\
\hline PROFREL & 0.12366 & 0.00494 & 0.52175 & 0.05117 & 0.03054 \\
\hline SHAROWN & 0.02306 & 0.0333 & 0.88147 & 0.00259 & 0.02177 \\
\hline PAYPERF & -0.01957 & 0.02198 & 0.15597 & -0.02207 & 0.03005 \\
\hline EMPSUPV & -0.0022 & 0.05696 & -0.04761 & -0.03558 & 0.17021 \\
\hline SUPVTAKE & -0.01536 & 0.01399 & 0.04817 & -0.01543 & 0.59907 \\
\hline SUPVPAY & 0.08001 & 0.00062 & 0.08143 & -0.05086 & 0.40251 \\
\hline SUPVDISM & 0.03522 & -0.03999 & 0.01423 & 0.05154 & 0.5598 \\
\hline \multirow[t]{2}{*}{ Variable } & Rotated & Rotated & Rotated & Rotated & Rotated \\
\hline & Factor 6 & Factor 7 & Factor & Factor 9 & Factor 10 \\
\hline EMPSHELP & 0.0588 & 0.03931 & 0.0428 & -0.00368 & 0.02196 \\
\hline DIRECONS & 0.99816 & 0.00775 & 0.03208 & 0.04232 & 0.00848 \\
\hline$I M P R M G M T$ & -0.12228 & 0.03947 & 0.08326 & -0.03146 & 0.0335 \\
\hline DECSATOP & 0.00538 & -0.05919 & -0.10777 & 0.15131 & 0.0014 \\
\hline EMPSCHAN & -0.00073 & 0.06622 & -0.02029 & -0.57696 & 0.0105 \\
\hline EMPSNOCO & 0.07347 & -0.1271 & 0.0086 & 0.8375 & 0.00687 \\
\hline CONSTARG & 0.02872 & 0.12667 & -0.05945 & -0.18096 & -0.03129 \\
\hline PARTBRIE & 0.00773 & 0.99571 & 0.02373 & -0.08657 & -0.00376 \\
\hline DISCUSS & 0.07666 & 0.11947 & 0.10532 & -0.15142 & 0.0077 \\
\hline PROFREL & 0.12366 & 0.00494 & 0.52175 & 0.05117 & 0.03054 \\
\hline SHAROWN & 0.02306 & 0.0333 & 0.88147 & 0.00259 & 0.02177 \\
\hline PAYPERF & -0.01957 & 0.02198 & 0.15597 & -0.02207 & 0.03005 \\
\hline EMPSUPV & -0.0022 & 0.05696 & -0.04761 & -0.03558 & 0.17021 \\
\hline$S U P V T A K E$ & -0.01536 & 0.01399 & 0.04817 & -0.01543 & 0.59907 \\
\hline SUPVPAY & 0.08001 & 0.00062 & 0.08143 & -0.05086 & 0.40251 \\
\hline SUPVDISM & 0.03522 & -0.03999 & 0.01423 & 0.05154 & 0.5598 \\
\hline
\end{tabular}


Table 10: Effect of policies and proportion of women at management on different measures of relative performance, as measured by managers.

\begin{tabular}{|c|c|c|c|c|c|c|c|c|}
\hline & \multicolumn{2}{|c|}{ FULLYCOM } & \multicolumn{2}{|c|}{ LABPROD } & \multicolumn{2}{|c|}{ PRODQUAL } & \multicolumn{2}{|c|}{ FINPERF } \\
\hline & Model I & Model II & Model I & Model II & $\underline{\text { Model I }}$ & Model II & Model I & Model II \\
\hline PROPFEMG & & $\begin{array}{r}-3.930^{*} \\
(2.218)\end{array}$ & & $\begin{array}{r}-0.780 \\
(2.307)\end{array}$ & & $\begin{array}{l}-0.597 \\
(2.253)\end{array}$ & & $\begin{array}{r}-0.604 \\
(2.271)\end{array}$ \\
\hline PROPWOM & & $\begin{array}{l}4.330^{*} \\
(2.259)\end{array}$ & & $\begin{array}{l}4.944^{* * *} \\
(2.362)\end{array}$ & & $\begin{array}{l}1.497 \\
(2.313)\end{array}$ & & $\begin{array}{l}2.342 \\
(2.392)\end{array}$ \\
\hline EMPSHELP & $\begin{array}{l}0.117^{* *} \\
(0.048)\end{array}$ & $\begin{array}{l}0.290^{* *} \\
(0.109)\end{array}$ & $\begin{array}{r}-0.013 \\
(0.051)\end{array}$ & $\begin{array}{l}0.130 \\
(0.113)\end{array}$ & $\begin{array}{l}-0.054 \\
(0.049)\end{array}$ & $\begin{array}{r}-0.052 \\
(0.108)\end{array}$ & $\begin{array}{l}-0.048 \\
(0.049)\end{array}$ & $\begin{array}{l}0.114 \\
(0.109)\end{array}$ \\
\hline$H E L P \times F E M G$ & & $\begin{array}{l}0.712^{* *} \\
(0.225)\end{array}$ & & $\begin{array}{l}0.263 \\
(0.244)\end{array}$ & & $\begin{array}{l}0.289 \\
(0.227)\end{array}$ & & $\begin{array}{l}0.406^{*} \\
(0.228)\end{array}$ \\
\hline$H E L P \times W O M$ & & $\begin{array}{c}-0.754^{* *} \\
(0.248)\end{array}$ & & $\begin{array}{r}-0.373 \\
(0.263)\end{array}$ & & $\begin{array}{r}-0.133 \\
(0.246)\end{array}$ & & $\begin{array}{c}-0.518^{* *} \\
(0.248)\end{array}$ \\
\hline DIRECONS & $\begin{array}{r}-0.021 \\
(0.054)\end{array}$ & $\begin{array}{c}-0.112 \\
(0.108)\end{array}$ & $\begin{array}{l}0.066 \\
(0.057)\end{array}$ & $\begin{array}{l}0.154 \\
(0.114)\end{array}$ & $\begin{array}{l}0.114^{* *} \\
(0.055)\end{array}$ & $\begin{array}{l}-0.101 \\
(0.109)\end{array}$ & $\begin{array}{l}0.055 \\
(0.054)\end{array}$ & $\begin{array}{l}0.021 \\
(0.110)\end{array}$ \\
\hline$D C O N S \times F E M G$ & & $\begin{array}{l}-0.068 \\
(0.246)\end{array}$ & & $\begin{array}{r}-0.164 \\
(0.273)\end{array}$ & & $\begin{array}{c}-0.609^{* *} \\
(0.252)\end{array}$ & & $\begin{array}{c}-0.637^{* *} \\
(0.255)\end{array}$ \\
\hline$D C O N S \times W O M$ & & $\begin{array}{l}0.205 \\
(0.261)\end{array}$ & & $\begin{array}{l}-0.191 \\
(0.283)\end{array}$ & & $\begin{array}{l}0.729^{* *} \\
(0.265)\end{array}$ & & $\begin{array}{l}0.420 \\
(0.270)\end{array}$ \\
\hline IMPRMGMT & $\begin{array}{r}-0.073 \\
(0.128)\end{array}$ & $\begin{array}{r}-0.102 \\
(0.252)\end{array}$ & $\begin{array}{l}-0.370^{* *} \\
(0.135)\end{array}$ & $\begin{array}{c}-0.508^{*} \\
(0.270)\end{array}$ & $\begin{array}{l}-0.053 \\
(0.131)\end{array}$ & $\begin{array}{c}-0.421^{*} \\
(0.258)\end{array}$ & $\begin{array}{l}-0.230^{*} \\
(0.129)\end{array}$ & $\begin{array}{r}-0.210 \\
(0.257)\end{array}$ \\
\hline$I M G T \times F E M G$ & & $\begin{array}{c}-1.736^{* *} \\
(0.629)\end{array}$ & & $\begin{array}{c}-1.365^{* *} \\
(0.671)\end{array}$ & & $\begin{array}{c}-1.609^{* * *} \\
(0.653)\end{array}$ & & $\begin{array}{c}-2.406^{* *} \\
(0.636)\end{array}$ \\
\hline$I M G T \times W O M$ & & $\begin{array}{l}1.220^{*} \\
(0.636)\end{array}$ & & $\begin{array}{l}1.053 \\
(0.686)\end{array}$ & & $\begin{array}{l}1.666^{* *} \\
(0.666)\end{array}$ & & $\begin{array}{l}1.464^{* *} \\
(0.653)\end{array}$ \\
\hline DECSATOP & $\begin{array}{l}0.238^{* *} \\
(0.050)\end{array}$ & $\begin{array}{l}0.385^{* *} \\
(0.107)\end{array}$ & $\begin{array}{l}0.058 \\
(0.054)\end{array}$ & $\begin{array}{l}0.073 \\
(0.113)\end{array}$ & $\begin{array}{l}0.033 \\
(0.051)\end{array}$ & $\begin{array}{l}0.107 \\
(0.110)\end{array}$ & $\begin{array}{l}0.043 \\
(0.052)\end{array}$ & $\begin{array}{l}0.242^{* *} \\
(0.111)\end{array}$ \\
\hline$D T O P \times F E M G$ & & $\begin{array}{c}-0.092 \\
(0.238)\end{array}$ & & $\begin{array}{r}-0.112 \\
(0.255)\end{array}$ & & $\begin{array}{l}-0.058 \\
(0.237)\end{array}$ & & $\begin{array}{l}0.124 \\
(0.245)\end{array}$ \\
\hline$D T O P \times W O M$ & & $\begin{array}{r}-0.315 \\
(0.257)\end{array}$ & & $\begin{array}{l}0.019 \\
(0.269)\end{array}$ & & $\begin{array}{r}-0.107 \\
(0.255)\end{array}$ & & $\begin{array}{r}-0.490 \\
(0.262)\end{array}$ \\
\hline EMPSCHAN & $\begin{array}{c}0.411^{* *} \\
(0.064)\end{array}$ & $\begin{array}{l}0.310^{* *} \\
(0.132)\end{array}$ & $\begin{array}{c}0.189^{* *} \\
(0.069)\end{array}$ & $\begin{array}{l}0.279^{* *} \\
(0.139)\end{array}$ & $\begin{array}{c}0.222^{* *} \\
(0.066)\end{array}$ & $\begin{array}{c}0.345^{* *} \\
(0.136)\end{array}$ & $\begin{array}{c}0.044 \\
(0.066)\end{array}$ & $\begin{array}{l}0.101 \\
(0.136)\end{array}$ \\
\hline$C H A N \times F E M G$ & & $\begin{array}{l}0.251 \\
(0.318)\end{array}$ & & $\begin{array}{c}-0.058 \\
(0.337)\end{array}$ & & $\begin{array}{l}0.536^{*} \\
(0.312)\end{array}$ & & $\begin{array}{l}0.136 \\
(0.324)\end{array}$ \\
\hline$C H A N \times W O M$ & & $\begin{array}{l}0.113 \\
(0.313)\end{array}$ & & $\begin{array}{r}-0.104 \\
(0.335)\end{array}$ & & $\begin{array}{r}-0.496 \\
(0.218)\end{array}$ & & $\begin{array}{r}-0.112 \\
(0.331)\end{array}$ \\
\hline EMPSNOCO & $\begin{array}{l}-0.405^{* *} \\
(0.065)\end{array}$ & $\begin{array}{r}-0.188 \\
(0.133)\end{array}$ & $\begin{array}{l}-0.038^{* * *} \\
(0.069)\end{array}$ & $\begin{array}{l}0.251^{*} \\
(0.139)\end{array}$ & $\begin{array}{r}-0.054 \\
(0.067)\end{array}$ & $\begin{array}{c}-0.279^{* *} \\
(0.138)\end{array}$ & $\begin{array}{r}-0.021 \\
(0.067)\end{array}$ & $\begin{array}{l}-0.057 \\
(0.137)\end{array}$ \\
\hline
\end{tabular}




\begin{tabular}{|c|c|c|c|c|c|c|c|c|}
\hline & \multicolumn{2}{|c|}{ FULLYCOM } & \multicolumn{2}{|c|}{$L A B P R O D$} & \multicolumn{2}{|c|}{ PRODQUAL } & \multicolumn{2}{|c|}{ FINPERF } \\
\hline & $\underline{\underline{\text { Model II }}}$ & Model II & Model I & $\underline{\underline{\text { Model II }}}$ & Model I & Model II & Model I & Model II \\
\hline$N O C O \times F E M G$ & & $\begin{array}{l}0.197 \\
(0.316)\end{array}$ & & $\begin{array}{l}0.197 \\
(0.316)\end{array}$ & & $\begin{array}{l}0.209 \\
(0.316)\end{array}$ & & $\begin{array}{l}0.117 \\
(0.319)\end{array}$ \\
\hline$N O C O \times W O M$ & & $\begin{array}{r}-0.509 \\
(0.324)\end{array}$ & & $\begin{array}{c}-0.597^{*} \\
(0.341)\end{array}$ & & $\begin{array}{c}-0.715^{* *} \\
(0.337)\end{array}$ & & $\begin{array}{l}0.164 \\
(0.334)\end{array}$ \\
\hline CONSTARG & $\begin{array}{l}0.315^{* *} \\
(0.065)\end{array}$ & $\begin{array}{l}0.573^{* *} \\
(0.231)\end{array}$ & $\begin{array}{l}0.287^{* *} \\
(0.065)\end{array}$ & $\begin{array}{l}0.263 \\
(0.241)\end{array}$ & $\begin{array}{l}0.134 \\
(0.112)\end{array}$ & $\begin{array}{l}0.025 \\
(0.234)\end{array}$ & $\begin{array}{l}0.111 \\
(0.112)\end{array}$ & $\begin{array}{l}0.398^{*} \\
(0.235)\end{array}$ \\
\hline$C T A R \times F E M G$ & & $\begin{array}{l}0.585 \\
(0.521)\end{array}$ & & $\begin{array}{l}0.219 \\
(0.570)\end{array}$ & & $\begin{array}{l}-0.091 \\
(0.527)\end{array}$ & & $\begin{array}{l}0.273 \\
(0.529)\end{array}$ \\
\hline$C T A R \times W O M$ & & $\begin{array}{c}-0.885^{* *} \\
(0.554)\end{array}$ & & $\begin{array}{r}-0.074 \\
(0.601)\end{array}$ & & $\begin{array}{l}0.307 \\
(0.561)\end{array}$ & & $\begin{array}{r}-0.713 \\
(0.562)\end{array}$ \\
\hline PARTBRIE & $\begin{array}{l}0.117^{* *} \\
(0.054)\end{array}$ & $\begin{array}{l}0.009 \\
(0.114)\end{array}$ & $\begin{array}{l}0.142^{\text {*** }} \\
(0.058)\end{array}$ & $\begin{array}{l}0.168 \\
(0.121)\end{array}$ & $\begin{array}{l}0.156^{* *} \\
(0.055)\end{array}$ & $\begin{array}{l}0.113 \\
(0.117)\end{array}$ & $\begin{array}{l}0.123^{* * *} \\
(0.054)\end{array}$ & $\begin{array}{l}0.080 \\
(0.116)\end{array}$ \\
\hline$P B R I \times F E M G$ & & $\begin{array}{l}0.219 \\
(0.256)\end{array}$ & & $\begin{array}{c}0.253 \\
(0.273)\end{array}$ & & $\begin{array}{r}-0.017 \\
(0.258)\end{array}$ & & $\begin{array}{l}-0.181 \\
(0.254)\end{array}$ \\
\hline$P B R I \times W O M$ & & $\begin{array}{l}0.061 \\
(0.275)\end{array}$ & & $\begin{array}{c}-0.217 \\
(0.290)\end{array}$ & & $\begin{array}{l}0.057 \\
(0.281)\end{array}$ & & $\begin{array}{l}0.241 \\
(0.274)\end{array}$ \\
\hline DISCUSS & $\begin{array}{l}0.350^{* *} \\
(0.138)\end{array}$ & $\begin{array}{l}0.546^{* *} \\
(0.268)\end{array}$ & $\begin{array}{r}-0.029 \\
(0.151)\end{array}$ & $\begin{array}{r}-0.055 \\
(0.291)\end{array}$ & $\begin{array}{r}-0.176 \\
(0.144)\end{array}$ & $\begin{array}{r}-0.160 \\
(0.281)\end{array}$ & $\begin{array}{l}-0.006 \\
(0.144)\end{array}$ & $\begin{array}{r}-0.052 \\
(0.281)\end{array}$ \\
\hline$D I S C \times F E M G$ & & $\begin{array}{l}0.548 \\
(0.627)\end{array}$ & & $\begin{array}{l}0.304 \\
(0.657)\end{array}$ & & $\begin{array}{c}-0.040 \\
(0.650)\end{array}$ & & $\begin{array}{l}0.597 \\
(0.649)\end{array}$ \\
\hline$D I S C \times W O M$ & & $\begin{array}{r}-0.671 \\
(0.663)\end{array}$ & & $\begin{array}{r}-0.337 \\
(0.719)\end{array}$ & & $\begin{array}{c}-0.272 \\
(0.697)\end{array}$ & & $\begin{array}{c}-0.486 \\
(0.693)\end{array}$ \\
\hline PROFREL & $\begin{array}{l}0.080 \\
(0.132)\end{array}$ & $\begin{array}{l}0.061 \\
(0.250)\end{array}$ & $\begin{array}{l}0.348^{* *} \\
(0.142)\end{array}$ & $\begin{array}{l}0.465^{*} \\
(0.263)\end{array}$ & $\begin{array}{l}0.093 \\
(0.134)\end{array}$ & $\begin{array}{r}-0.197 \\
(0.254)\end{array}$ & $\begin{array}{l}0.225^{*} \\
(0.134)\end{array}$ & $\begin{array}{l}0.286 \\
(0.251)\end{array}$ \\
\hline$P R E L \times F E M G$ & & $\begin{array}{l}0.750 \\
(0.643)\end{array}$ & & $\begin{array}{l}1.368^{* *} \\
(0.681)\end{array}$ & & $\begin{array}{l}0.529 \\
(0.656)\end{array}$ & & $\begin{array}{l}1.036 \\
(0.646)\end{array}$ \\
\hline$P R E L \times W O M$ & & $\begin{array}{r}-0.449 \\
(0.638)\end{array}$ & & $\begin{array}{c}-1.202^{*} \\
(0.676)\end{array}$ & & $\begin{array}{l}0.191 \\
(0.655)\end{array}$ & & $\begin{array}{r}-0.886 \\
(0.650)\end{array}$ \\
\hline SHAROWN & $\begin{array}{l}0.223 \\
(0.153)\end{array}$ & $\begin{array}{r}-0.300 \\
(0.292)\end{array}$ & $\begin{array}{l}0.492^{* *} \\
(0.153)\end{array}$ & $\begin{array}{l}0.142 \\
(0.300)\end{array}$ & $\begin{array}{r}-0.176 \\
(0.154)\end{array}$ & $\begin{array}{r}-0.416 \\
(0.294)\end{array}$ & $\begin{array}{l}0.586^{* *} \\
(0.153)\end{array}$ & $\begin{array}{l}0.284 \\
(0.291)\end{array}$ \\
\hline$S H R O W \times F E M G$ & & $\begin{array}{r}-0.502 \\
(0.736)\end{array}$ & & $\begin{array}{r}-0.620 \\
(0.779)\end{array}$ & & $\begin{array}{c}0.226 \\
(0.745)\end{array}$ & & $\begin{array}{c}-0.075 \\
(0.762)\end{array}$ \\
\hline$S H R O W \times W O M$ & & $\begin{array}{l}1.492 \\
(0.725)\end{array}$ & & $\begin{array}{l}1.169 \\
(0.757)\end{array}$ & & $\begin{array}{l}0.758 \\
(0.735)\end{array}$ & & $\begin{array}{l}0.887 \\
(0.747)\end{array}$ \\
\hline PAYPERF & $\begin{array}{l}-0.295^{* *} \\
(0.126)\end{array}$ & $\begin{array}{l}0.085 \\
(0.245)\end{array}$ & $\begin{array}{l}0.152 \\
(0.136)\end{array}$ & $\begin{array}{c}-0.232 \\
(0.264)\end{array}$ & $\begin{array}{l}0.022 \\
(0.130)\end{array}$ & $\begin{array}{l}0.247 \\
(0.252)\end{array}$ & $\begin{array}{l}0.259^{* *} \\
(0.129)\end{array}$ & $\begin{array}{r}-0.113 \\
(0.251)\end{array}$ \\
\hline$P A Y P \times F E M G$ & & $\begin{array}{c}0.864 \\
(0.611)\end{array}$ & & $\begin{array}{r}-0.233 \\
(0.671)\end{array}$ & & $\begin{array}{l}1.071^{*} \\
(0.623)\end{array}$ & & $\begin{array}{l}1.216^{*} \\
(0.631)\end{array}$ \\
\hline
\end{tabular}




\begin{tabular}{|c|c|c|c|c|c|c|c|c|}
\hline & \multicolumn{2}{|c|}{ FULLYCOM } & \multicolumn{2}{|c|}{ LABPROD } & \multicolumn{2}{|c|}{ PRODQUAL } & \multicolumn{2}{|c|}{ FINPERF } \\
\hline & Model I & Model II & Model I & Model II & Model I & Model II & $\underline{\text { Model I }}$ & Model II \\
\hline$P A Y P \times W O M$ & & $\begin{array}{l}-1.348^{* * *} \\
(0.609)\end{array}$ & & $\begin{array}{l}1.216^{*} \\
(0.669)\end{array}$ & & $\begin{array}{r}-1.099^{*} \\
(0.633)\end{array}$ & & $\begin{array}{l}0.168 \\
(0.630)\end{array}$ \\
\hline EMPSUPV & $\begin{array}{l}0.027 \\
(0.043)\end{array}$ & $\begin{array}{l}0.042 \\
(0.086)\end{array}$ & $\begin{array}{l}0.043 \\
(0.045)\end{array}$ & $\begin{array}{l}0.109 \\
(0.088)\end{array}$ & $\begin{array}{l}0.060 \\
(0.043)\end{array}$ & $\begin{array}{l}0.139 \\
(0.088)\end{array}$ & $\begin{array}{l}0.031 \\
(0.044)\end{array}$ & $\begin{array}{l}0.095 \\
(0.087)\end{array}$ \\
\hline$E S U P \times F E M G$ & & $\begin{array}{r}-0.288 \\
(0.204)\end{array}$ & & $\begin{array}{l}0.185 \\
(0.205)\end{array}$ & & $\begin{array}{l}0.148 \\
(0.194)\end{array}$ & & $\begin{array}{l}0.371^{*} \\
(0.210)\end{array}$ \\
\hline$E S U P \times W O M$ & & $\begin{array}{l}0.135 \\
(0.208)\end{array}$ & & $\begin{array}{r}-0.277 \\
(0.209)\end{array}$ & & $\begin{array}{r}-0.181 \\
(0.202)\end{array}$ & & $\begin{array}{c}-0.375^{*} \\
(0.216)\end{array}$ \\
\hline SUPVTAKE & $\begin{array}{l}-0.040 \\
(0.124)\end{array}$ & $\begin{array}{l}0.156 \\
(0.255)\end{array}$ & $\begin{array}{l}-0.167 \\
(0.133)\end{array}$ & $\begin{array}{r}-0.106 \\
(0.271)\end{array}$ & $\begin{array}{c}-0.234^{*} \\
(0.130)\end{array}$ & $\begin{array}{r}-0.176 \\
(0.267)\end{array}$ & $\begin{array}{l}0.038 \\
(0.128)\end{array}$ & $\begin{array}{r}0.139 \\
(0.267)\end{array}$ \\
\hline$S T K E \times F E M G$ & & $\begin{array}{r}-0.738 \\
(0.622)\end{array}$ & & $\begin{array}{l}0.368 \\
(0.687)\end{array}$ & & $\begin{array}{r}-0.572 \\
(0.646)\end{array}$ & & $\begin{array}{r}-0.315 \\
(0.637)\end{array}$ \\
\hline$S T K E \times W O M$ & & $\begin{array}{l}0.120 \\
(0.611)\end{array}$ & & $\begin{array}{c}-0.328 \\
(0.667)\end{array}$ & & $\begin{array}{r}-0.278 \\
(0.637)\end{array}$ & & $\begin{array}{l}0.088 \\
(0.634)\end{array}$ \\
\hline$S U P V P A Y$ & $\begin{array}{l}0.245 \\
(0.270)\end{array}$ & $\begin{array}{l}0.023 \\
(0.573)\end{array}$ & $\begin{array}{l}0.161 \\
(0.306)\end{array}$ & $\begin{array}{l}-0.108 \\
(0.650)\end{array}$ & $\begin{array}{l}0.032 \\
(0.283)\end{array}$ & $\begin{array}{l}0.360 \\
(0.597)\end{array}$ & $\begin{array}{l}0.135 \\
(0.291)\end{array}$ & $\begin{array}{l}0.329 \\
(0.622)\end{array}$ \\
\hline$S P A Y \times F E M G$ & & $\begin{array}{r}-0.357 \\
(1.309)\end{array}$ & & $\begin{array}{r}-0.137 \\
(1.450)\end{array}$ & & $\begin{array}{l}0.645 \\
(1.317)\end{array}$ & & $\begin{array}{l}0.981 \\
(1.331)\end{array}$ \\
\hline$S P A Y \times W O M$ & & $\begin{array}{l}1.050 \\
(1.509)\end{array}$ & & $\begin{array}{l}1.044 \\
(1.680)\end{array}$ & & $\begin{array}{r}-0.880 \\
(1.561)\end{array}$ & & $\begin{array}{r}-0.678 \\
(1.601)\end{array}$ \\
\hline SUPVDISM & $\begin{array}{l}-0.128 \\
(0.217)\end{array}$ & $\begin{array}{r}-0.656 \\
(0.412)\end{array}$ & $\begin{array}{l}0.070 \\
(0.237)\end{array}$ & $\begin{array}{l}0.837^{*} \\
(0.441)\end{array}$ & $\begin{array}{l}0.071 \\
(0.223)\end{array}$ & $\begin{array}{r}-0.261 \\
(0.422)\end{array}$ & $\begin{array}{r}-0.145 \\
(0.225)\end{array}$ & $\begin{array}{r}-0.147 \\
(0.429)\end{array}$ \\
\hline$S D I S M \times F E M G$ & & $\begin{array}{l}1.014 \\
(1.219)\end{array}$ & & $\begin{array}{l}0.829 \\
(1.314)\end{array}$ & & $\begin{array}{l}0.084 \\
(1.250)\end{array}$ & & $\begin{array}{l}0.303 \\
(1.330)\end{array}$ \\
\hline$S D I S M \times W O M$ & & $\begin{array}{l}0.680 \\
(1.235)\end{array}$ & & $\begin{array}{r}-2.438^{*} \\
(1.335)\end{array}$ & & $\begin{array}{l}0.692 \\
(1.272)\end{array}$ & & $\begin{array}{l}0.079 \\
(1.292)\end{array}$ \\
\hline $\begin{array}{l}\text { 1-digit Industry } \\
\text { Dummies }\end{array}$ & Yes & Yes & Yes & Yes & Yes & Yes & Yes & Yes \\
\hline $\begin{array}{c}\text { Percentages of } \\
\text { Workforce in each } \\
\text { Occupation }\end{array}$ & Yes & Yes & Yes & Yes & Yes & Yes & Yes & Yes \\
\hline $\begin{array}{c}\text { Firm } \\
\text { Characteristics }\end{array}$ & Yes & Yes & Yes & Yes & Yes & Yes & Yes & Yes \\
\hline $\begin{array}{c}\text { Other Policies } \\
\text { Dummies }\end{array}$ & Yes & Yes & Yes & Yes & Yes & Yes & Yes & Yes \\
\hline $\begin{array}{l}\text { Number of } \\
\text { observations }\end{array}$ & 1457 & 1376 & 1214 & 1376 & 1336 & 1261 & 1279 & 1211 \\
\hline$L-R$ test $\chi^{2}$ & $438.87^{* *}$ & $475.05^{* *}$ & $103.41^{* *}$ & $475.05^{* *}$ & $142.93^{* *}$ & $183.52^{* *}$ & $92.94^{* *}$ & $144.38^{* *}$ \\
\hline
\end{tabular}

Significant at the $10 \%$ level. ${ }^{* *}$ Significant at the 5\% level 


\section{Appendix: Description of the Variables Analysed}

\begin{tabular}{|c|c|c|c|}
\hline $\begin{array}{l}\text { Variable } \\
\text { Name }\end{array}$ & Variable Description & Measurement & $\begin{array}{c}\text { Mean } \\
\text { (Std. Dev.) }\end{array}$ \\
\hline PROPFEMG & Proportion of managers who are women & $\begin{array}{l}\text { Continuous } \\
\text { Variable }\end{array}$ & $\begin{array}{l}0.319 \\
(0.303)\end{array}$ \\
\hline PROPWOM & $\begin{array}{l}\text { Proportion of total number of employees who are } \\
\text { women }\end{array}$ & $\begin{array}{l}\text { Continuous } \\
\text { Variable }\end{array}$ & $\begin{array}{l}0.496 \\
(0.285)\end{array}$ \\
\hline EMPSHELP & $\begin{array}{l}\text { Whether managers ask employees to help them in } \\
\text { unspecified ways }\end{array}$ & $\begin{array}{l}\text { Discrete scale of } \\
\text { agreement } 1 \text { to } 5\end{array}$ & $\begin{array}{l}3.324 \\
(1.145)\end{array}$ \\
\hline$A V G E D U Y R^{*}$ & $\begin{array}{l}\text { Average years of education of employees at the } \\
\text { workplace }\end{array}$ & $\begin{array}{l}\text { Continuous } \\
\text { Variable }\end{array}$ & $\begin{array}{l}10.661 \\
(2.275)\end{array}$ \\
\hline DIRECONS & $\begin{array}{l}\text { Whether managers rather consult directly with } \\
\text { employees than with representatives }\end{array}$ & $\begin{array}{l}\text { Discrete scale of } \\
\text { agreement } 1 \text { to } 5\end{array}$ & $\begin{array}{l}3.652 \\
(1.106)\end{array}$ \\
\hline$I M P R M G M T$ & $\begin{array}{l}\text { Whether managers are considered a channel through } \\
\text { which employees can make suggestion }\end{array}$ & Dummy $0 / 1$ & $\begin{array}{l}0.248 \\
(0.432)\end{array}$ \\
\hline DECSATOP & $\begin{array}{l}\text { Whether managers consider that those at top are best } \\
\text { placed to make decisions }\end{array}$ & $\begin{array}{l}\text { Discrete scale of } \\
\text { agreement } 1 \text { to } 5\end{array}$ & $\begin{array}{l}3.271 \\
(1.086)\end{array}$ \\
\hline EMPSCHAN & $\begin{array}{l}\text { Whether managers discuss with workers any change } \\
\text { before introducing it }\end{array}$ & $\begin{array}{l}\text { Discrete scale of } \\
\text { agreement } 1 \text { to } 5\end{array}$ & $\begin{array}{l}3.740 \\
(0.956)\end{array}$ \\
\hline EMPSNOCO & $\begin{array}{l}\text { Whether most decisions at workplace are made } \\
\text { without discussing them with employees }\end{array}$ & $\begin{array}{l}\text { Discrete scale of } \\
\text { agreement } 1 \text { to } 5\end{array}$ & $\begin{array}{l}2.258 \\
(0.980)\end{array}$ \\
\hline CONSTARG & $\begin{array}{l}\text { Whether managers set establishment targets in } \\
\text { consultation with employees }\end{array}$ & Dummy $0 / 1$ & $\begin{array}{l}0.465 \\
(0.499)\end{array}$ \\
\hline PARTBRIE & $\begin{array}{l}\text { Proportion of time in informative briefing meetings } \\
\text { given to employees to offer views and pose questions }\end{array}$ & $\begin{array}{l}\text { Discrete scale } \\
\quad 0 \text { to } 4\end{array}$ & $\begin{array}{l}1.978 \\
(1.048)\end{array}$ \\
\hline DISCUSS & $\begin{array}{l}\text { Whether the firm uses performance appraisals to give } \\
\text { feedback to employees, discuss their career moves } \\
\text { and set their personal objectives }\end{array}$ & Dummy $0 / 1$ & $\begin{array}{l}0.762 \\
(0.426)\end{array}$ \\
\hline PROFREL & Whether employees receive profit-related payment & Dummy $0 / 1$ & $\begin{array}{l}0.377 \\
(0.485)\end{array}$ \\
\hline SHAROWN & Whether there exist employee ownership plans & Dummy $0 / 1$ & $\begin{array}{l}0.232 \\
(0.422)\end{array}$ \\
\hline PAYPERF & Whether there exist pay per performance schemes & Dummy $0 / 1$ & $\begin{array}{l}0.260 \\
(0.439)\end{array}$ \\
\hline$E M P S U P V$ & $\begin{array}{l}\text { Proportion of non-managerial workers doing } \\
\text { supervisory tasks }\end{array}$ & $\begin{array}{l}\text { Discrete scale } 0 \\
\text { to } 6\end{array}$ & $\begin{array}{l}1.644 \\
(1.244)\end{array}$ \\
\hline$S U P V T A K E$ & $\begin{array}{l}\text { Whether supervisors have the authority to make } \\
\text { hiring decisions }\end{array}$ & Dummy $0 / 1$ & $\begin{array}{l}0.284 \\
(0.451)\end{array}$ \\
\hline
\end{tabular}




\begin{tabular}{|c|c|c|c|}
\hline $\begin{array}{l}\text { Variable } \\
\text { Name }\end{array}$ & Variable Description & Measurement & $\begin{array}{c}\text { Mean } \\
\text { (Std. Dev.) }\end{array}$ \\
\hline SUPVPAY & $\begin{array}{l}\text { Whether supervisors have the authority to decide on } \\
\text { pay rises }\end{array}$ & Dummy $0 / 1$ & $\begin{array}{l}0.435 \\
(0.204)\end{array}$ \\
\hline SUPVVDISM & $\begin{array}{l}\text { Whether supervisors have the authority to decide on } \\
\text { dismissals for unsatisfactory performance }\end{array}$ & Dummy $0 / 1$ & $\begin{array}{l}0.076 \\
(0.265)\end{array}$ \\
\hline NUMEMPS & Total number of employees at the workplace & $\begin{array}{l}\text { Continuous } \\
\text { Variable }\end{array}$ & $\begin{array}{l}288.743 \\
(847.311)\end{array}$ \\
\hline$A V G A G E^{*}$ & Average age of employees at the workplace & $\begin{array}{l}\text { Continuous } \\
\text { Variable }\end{array}$ & $\begin{array}{r}38.970 \\
(5.804)\end{array}$ \\
\hline$A V G E D U Y R^{*}$ & $\begin{array}{l}\text { Average years of education of employees at the } \\
\text { workplace }\end{array}$ & $\begin{array}{l}\text { Continuous } \\
\text { Variable }\end{array}$ & $\begin{array}{l}10.661 \\
(2.275)\end{array}$ \\
\hline PROPRFS & $\begin{array}{l}\text { Proportion of total number of employees who are } \\
\text { professional workers }\end{array}$ & $\begin{array}{l}\text { Continuous } \\
\text { Variable }\end{array}$ & $\begin{array}{l}0.150 \\
(0.236)\end{array}$ \\
\hline PROTECS & $\begin{array}{l}\text { Proportion of total number of employees who are } \\
\text { technical workers }\end{array}$ & $\begin{array}{l}\text { Continuous } \\
\text { Variable }\end{array}$ & $\begin{array}{l}0.090 \\
(0.170)\end{array}$ \\
\hline PROCLERS & $\begin{array}{l}\text { Proportion of total number of employees who are } \\
\text { clerical or secretarial workers }\end{array}$ & $\begin{array}{l}\text { Continuous } \\
\text { Variable }\end{array}$ & $\begin{array}{l}0.204 \\
(0.254)\end{array}$ \\
\hline PROSKILS & $\begin{array}{l}\text { Proportion of total number of employees who are } \\
\text { skilled manual workers }\end{array}$ & $\begin{array}{l}\text { Continuous } \\
\text { Variable }\end{array}$ & $\begin{array}{l}0.108 \\
(0.209)\end{array}$ \\
\hline PROSEVCS & $\begin{array}{l}\text { Proportion of total number of employees who work } \\
\text { in personal service occupations }\end{array}$ & $\begin{array}{l}\text { Continuous } \\
\text { Variable }\end{array}$ & $\begin{array}{l}0.087 \\
(0.220)\end{array}$ \\
\hline PROOPER & $\begin{array}{l}\text { Proportion of total number of employees who work } \\
\text { in operative and assembly occupations }\end{array}$ & $\begin{array}{l}\text { Continuous } \\
\text { Variable }\end{array}$ & $\begin{array}{l}0.114 \\
(0.249)\end{array}$ \\
\hline PROSALES & $\begin{array}{l}\text { Proportion of total number of employees work in } \\
\text { sales occupations }\end{array}$ & $\begin{array}{l}\text { Continuous } \\
\text { Variable }\end{array}$ & $\begin{array}{l}0.112 \\
(0.251)\end{array}$ \\
\hline INDEPEND & $\begin{array}{l}\text { Whether the interviewed workplace is an independent } \\
\text { organisation }\end{array}$ & Dummy $0 / 1$ & $\begin{array}{l}0.200 \\
(0.400)\end{array}$ \\
\hline FOREING & $\begin{array}{l}\text { Whether the organisation is mostly owned by foreign } \\
\text { capital }\end{array}$ & Dummy $0 / 1$ & $\begin{array}{l}0.309 \\
(0.462)\end{array}$ \\
\hline PUBLIC & Whether the firm is a public sector company & Dummy $0 / 1$ & $\begin{array}{l}0.104 \\
(0.305)\end{array}$ \\
\hline$L O N G E V$ & Years of longevity of the workplace & $\begin{array}{l}\text { Continuous } \\
\text { Variable }\end{array}$ & $\begin{array}{l}35.603 \\
(48.269)\end{array}$ \\
\hline SIC & SIC 1992 Code of main activity of the establishment & 12 Dummies $0 / 1$ & \\
\hline UNION & $\begin{array}{l}\text { Whether there any type of union or staff association } \\
\text { at workplace }\end{array}$ & Dummy $0 / 1$ & $\begin{array}{l}0.659 \\
(0.474)\end{array}$ \\
\hline
\end{tabular}




\begin{tabular}{|c|c|c|c|}
\hline $\begin{array}{l}\text { Variable } \\
\text { Name }\end{array}$ & Variable Description & Measurement & $\begin{array}{c}\text { Mean } \\
\text { (Std. Dev.) }\end{array}$ \\
\hline LTEMPLOY & $\begin{array}{l}\text { Whether employees of the organisation are lead to } \\
\text { expect a long-term employment relationship }\end{array}$ & $\begin{array}{l}\text { Discrete scale of } \\
\text { agreement } 1 \text { to } 5\end{array}$ & $\begin{array}{l}3.785 \\
(0.976)\end{array}$ \\
\hline WITHINPR & $\begin{array}{l}\text { Extent to which job vacancies are covered primarily } \\
\text { through internal application }\end{array}$ & $\begin{array}{l}\text { Discrete scale } \\
\quad 1 \text { to } 3\end{array}$ & $\begin{array}{l}1.375 \\
(0.530)\end{array}$ \\
\hline FOREQOPS & $\begin{array}{l}\text { Whether the organisation has a formal written policy } \\
\text { on equal opportunities or managing diversity }\end{array}$ & Dummy $0 / 1$ & $\begin{array}{l}0.811 \\
(0.391)\end{array}$ \\
\hline ЕМРМОТН & $\begin{array}{l}\text { Whether the organisation has a special policy to hire } \\
\text { women returning to work after having children }\end{array}$ & Dummy $0 / 1$ & $\begin{array}{l}0.162 \\
(0.368)\end{array}$ \\
\hline FULLYCOM & $\begin{array}{l}\text { Whether manager considers that employees are fully } \\
\text { committed to the values of the organisation }\end{array}$ & $\begin{array}{l}\text { Discrete scale of } \\
\text { agreement } 1 \text { to } 5\end{array}$ & $\begin{array}{l}3.690 \\
(0.846)\end{array}$ \\
\hline$\angle A B P R O D$ & $\begin{array}{l}\text { Manager's assessment of workplace labour } \\
\text { productivity compared to the rest of the industry }\end{array}$ & $\begin{array}{l}\text { Discrete scale } \\
\quad 1 \text { to } 5\end{array}$ & $\begin{array}{l}3.574 \\
(0.778)\end{array}$ \\
\hline PRODQUAL & $\begin{array}{l}\text { Manager's assessment of workplace's quality of } \\
\text { product/service compared to the rest of the industry }\end{array}$ & $\begin{array}{l}\text { Discrete scale } \\
\quad 1 \text { to } 5\end{array}$ & $\begin{array}{l}3.916 \\
(0.754)\end{array}$ \\
\hline FINPERF & $\begin{array}{l}\text { Manager's assessment of workplace's financial } \\
\text { performance compared to the rest of the industry }\end{array}$ & $\begin{array}{l}\text { Discrete scale } \\
\quad 1 \text { to } 5\end{array}$ & $\begin{array}{l}3.674 \\
(0.847)\end{array}$ \\
\hline CHPROFMG & $\begin{array}{l}\text { Evolution of the proportion of women in managerial } \\
\text { posts in the last } 5 \text { years }\end{array}$ & $\begin{array}{l}\text { Discrete scale } \\
\quad-2 \text { to } 2\end{array}$ & $\begin{array}{l}0.556 \\
(0.784)\end{array}$ \\
\hline CHLABPRO & $\begin{array}{l}\text { Evolution of labour productivity at the workplace in } \\
\text { the last } 5 \text { years }\end{array}$ & $\begin{array}{l}\text { Discrete scale } \\
\quad-2 \text { to } 2\end{array}$ & $\begin{array}{l}0.319 \\
(0.303)\end{array}$ \\
\hline CHLABCST & $\begin{array}{l}\text { Evolution of labour costs at the workplace in the last } \\
5 \text { years }\end{array}$ & $\begin{array}{l}\text { Discrete scale } \\
\quad-2 \text { to } 2\end{array}$ & $\begin{array}{l}0.665 \\
(1.100)\end{array}$ \\
\hline CHDECMAK & $\begin{array}{l}\text { Evolution of employees' influence on managerial } \\
\text { decision-making in the last } 5 \text { years }\end{array}$ & $\begin{array}{l}\text { Discrete scale } \\
\quad-2 \text { to } 2\end{array}$ & $\begin{array}{l}0.593 \\
(0.712)\end{array}$ \\
\hline CHEMPREL & $\begin{array}{l}\text { Evolution of importance of employee relations in the } \\
\text { last } 5 \text { years }\end{array}$ & $\begin{array}{l}\text { Discrete scale } \\
\quad-2 \text { to } 2\end{array}$ & $\begin{array}{l}1.051 \\
(0.848)\end{array}$ \\
\hline CHPBR & $\begin{array}{l}\text { Evolution of the number of non-managers paid by } \\
\text { results in the last } 5 \text { years }\end{array}$ & $\begin{array}{l}\text { Discrete scale } \\
\quad-2 \text { to } 2\end{array}$ & $\begin{array}{l}0.432 \\
(0.737)\end{array}$ \\
\hline CHEMPINF & $\begin{array}{l}\text { Evolution of employees' autonomy at their jobs in the } \\
\text { last } 5 \text { years }\end{array}$ & $\begin{array}{l}\text { Discrete scale }-2 \\
\text { to } 2\end{array}$ & $\begin{array}{l}0.749 \\
(0.797)\end{array}$ \\
\hline
\end{tabular}

* Obtained from the employee survey records carried out by the WERS 98. 